\title{
Anthropogenic, Direct Pressures on Coastal Wetlands
}

OPEN ACCESS

Edited by:

Sumeet Gulati,

The University of British Columbia,

Canada

Reviewed by:

Christopher Gabler,

The University of Texas Rio Grande Valley, United States

Aurélie Davranche,

Université d'Angers, France

*Correspondence:

Alice Newton

anewton@ualg.pt

Specialty section:

This article was submitted to

Conservation,

a section of the journal

Frontiers in Ecology and Evolution

Received: 16 November 2019

Accepted: 27 April 2020

Published: 07 July 2020

Citation:

Newton A, Icely J, Cristina S, Perillo GME, Turner RE, Ashan D, Cragg S, Luo Y, TU C, Li Y, Zhang H, Ramesh $R$, Forbes $D L$, Solidoro $C$,

Béjaoui B, Gao S, Pastres $R$,

Kelsey $H$, Taillie $D$, Nhan N, Brito AC,

de Lima R and Kuenzer C (2020)

Anthropogenic, Direct Pressures on

Coastal Wetlands.

Front. Ecol. Evol. 8:144.

doi: 10.3389/fevo.2020.00144

\author{
Alice Newton ${ }^{1,2 *}$, John Icely 1,3 , Sonia Cristina ${ }^{1}$, Gerardo M. E. Perillo4, \\ R. Eugene Turner ${ }^{5}$, Dewan Ashan 6 , Simon Cragg ${ }^{7}$, Yongming Luo 8,9 , Chen $\mathrm{Tu}^{8}$, Yuan Li ${ }^{8}$, \\ Haibo Zhang ${ }^{8,10}$, Ramachandran Ramesh'11, Donald L. Forbes ${ }^{12}$, Cosimo Solidoro ${ }^{13}$, \\ Béchir Béjaoui ${ }^{14}$, Shu Gao ${ }^{15}$, Roberto Pastres ${ }^{16}$, Heath Kelsey ${ }^{17}$, Dylan Taillie ${ }^{17}$, \\ Nguyen Nhan ${ }^{18}$, Ana C. Brito ${ }^{19}$, Ricardo de Lima ${ }^{20}$ and Claudia Kuenzer ${ }^{21}$
}

\begin{abstract}
${ }^{1}$ Centre for Marine and Environmental Research, Gambelas Campus, University of Algarve, Faro, Portugal, ${ }^{2}$ NILU-IMPACT, Kjeller, Norway, ${ }^{3}$ Sagremarisco-Viveiros de Marisco, Lda., Vila do Bispo, Portugal, ${ }^{4}$ IADO-Instituto Argentino de Oceanografia, Blanca, Argentina, ${ }^{5}$ Department of Oceanography and Coastal Sciences, School of the Coast and Environment (SCE), Louisiana State University, Baton Rouge, LA, United States, ${ }^{6}$ Department of Sociology, Environmental and Business Economics, University of Southern Denmark, Odense, Denmark, ${ }^{7}$ Institute of Marine Sciences, School of Biological Sciences, University of Portsmouth, Portsmouth, United Kingdom, ${ }^{8}$ Yantai Institute of Coastal Zone Research, Chinese Academy of Sciences, Yantai, China, ${ }^{9}$ Institute of Soil Science, Chinese Academy of Sciences, Nanjing, China, ${ }^{10}$ School of Environmental and Resource Sciences, Zhejiang A\&F University, Hangzhou, China, ${ }^{11}$ National Centre for Sustainable Coastal Management, Ministry of Environment, Forests and Climate Change, Government of India, Anna University Campus, Chennai, India, ${ }^{12}$ Natural Resources Canada, Bedford Institute of Oceanography, Dartmouth, NS, Canada, ${ }^{13}$ OGS National Institute of Oceanography and Experimental Geophysics, Trieste, Italy, ${ }^{14}$ National Institute of Marine Sciences and Technology (INSTM) - Marine Environment Laboratory, Salammbô, Tunisia, ${ }^{15}$ State Key Laboratory of Estuarine and Coastal Research, East China Normal University, Shanghai, China, ${ }^{16}$ Department of Science Environment Computing and Statistics, Università Ca' Foscari Venezia, Venice, Italy, ${ }^{17}$ Center for Environmental Science, University of Maryland, Cambridge, Cambridge, MD, United States, ${ }^{18}$ Institute of Coastal and Offshore Engineering, Vietnam Academy for Water Resources, Hanoi, Vietnam, ${ }^{19}$ MARE - Centro de Ciências do Mar e do Ambiente, Faculdade de Ciências, Universidade de Lisboa, Lisbon, Portugal, ${ }^{20}$ Centre for Ecology, Evolution and Environmental Changes, Faculty of Science, University of Lisbon, Lisbon, Portugal, ${ }^{21}$ Department Land Surface, German Aerospace Center, Earth Observation Center, The German Remote Sensing Data Center, Deutsches Zentrum für Luft- und Raumfahrt (DLR), Wessling, Germany
\end{abstract}

Coastal wetlands, such as saltmarshes and mangroves that fringe transitional waters, deliver important ecosystem services that support human development. Coastal wetlands are complex social-ecological systems that occur at all latitudes, from polar regions to the tropics. This overview covers wetlands in five continents. The wetlands are of varying size, catchment size, human population and stages of economic development. Economic sectors and activities in and around the coastal wetlands and their catchments exert multiple, direct pressures. These pressures affect the state of the wetland environment, ecology and valuable ecosystem services. All the coastal wetlands were found to be affected in some ways, irrespective of the conservation status. The main economic sectors were agriculture, animal rearing including aquaculture, fisheries, tourism, urbanization, shipping, industrial development and mining. Specific human activities include land reclamation, damming, draining and water extraction, construction of ponds for aquaculture and salt extraction, construction of ports and marinas, dredging, discharge of effluents from urban and industrial areas and logging, in the case of mangroves, subsistence hunting and oil and gas extraction. The main pressures were loss of wetland habitat, changes in connectivity affecting hydrology and sedimentology, as well as contamination and pollution. These pressures lead to changes in environmental state, such as erosion, subsidence and hypoxia that threaten the sustainability of the wetlands. There are also changes in the state of the ecology, such as loss of saltmarsh plants and seagrasses, and mangrove trees, in tropical wetlands. Changes in the structure and function of the wetland ecosystems affect ecosystem 
services that are often underestimated. The loss of ecosystem services impacts human welfare as well as the regulation of climate change by coastal wetlands. These cumulative impacts and multi-stressors are further aggravated by indirect pressures, such as sea-level rise.

Keywords: coastal wetland, salt marsh, mangrove, seagrass, pressure, state and impact on human welfare, sustainability, climate change

\section{INTRODUCTION}

Transitional waters are naturally fringed by many types of coastal wetlands, such as tidal flats, seagrass meadows, saltmarshes and mangroves, that are an integral part of the transitional ecosystems (Perillo et al., 2019). The coastal wetlands covered in this article fringe river mouth systems, estuaries, deltas and other transitional waters, such as coastal lagoons and shallow, semi-enclosed, coastal systems, such as bays (Newton et al., 2013). They include a variety of habitats: mudflats, seagrass meadows, saltmarshes, and mangrove swamps. The article covers wetlands from the tropics, temperate zones and polar regions as examples to illustrate the main direct pressures (Figure $\mathbf{1}$ and Table 1). The wetlands have been chosen to give a broad range and variety, including very large wetlands (e.g., the Mekong Delta) and much smaller ones (e.g., Malanza).

The range of population and human pressures also varies from sparsely populated, (e.g., Mackenzie-Beaufort), to very large populations, (e.g., Yangtze-Changjiang). Nevertheless, the resident population numbers are not always the best indicator of human pressure, for example, the Venice municipality has a low resident population (about 85,000 ), but a very large number of visitors (20 million $\left.\mathrm{y}^{-1}\right)$.

The examples chosen include some very well-known systems, such as the Chesapeake Bay, but an effort has been made to also include some less well-known systems, such as the mangroves of Gulf of Papua and Malanza. Many other systems could have been chosen, but there were limitations to the length of the article, so information on some additional examples is included only in Supplementary Tables S1-S5. There is also a recent review of coastal wetlands in North Africa by El Mahrad et al. (2020).

The human pressures on wetlands are both direct and indirect. An example of a direct pressure is the loss of connectivity and interruptions to sediment supply as a result of constructing a dam. Indirect, human pressures are mostly related to climate change and these include rising temperature, acidification, changes in precipitation/runoff, as well as sea level rise. The aim of this article is to give an overview of the multiple, anthropogenic, direct pressures on coastal wetlands resulting from human activities, the effect that these pressures have on the state of the wetland and ecosystem services, as well as the eventual impacts on human welfare.

There are many possible frameworks for analyzing SocialEcological Systems such as coastal wetlands (Binder et al., 2013). The present analysis follows a 'Activity-Pressure-StateImpact on Human Welfare' approach, modified from the 'Driver Pressure State Impact Response' framework (DPSIR), (Gari et al., 2015; Patrício et al., 2016; Elliott et al., 2017).
This approach has been selected because it is widely used in international studies by international organizations, (e.g., the Organization for Economic Cooperation and Development, the European Environment Agency, the United Nations Environment Programme, and the United Nations World Ocean Assessment). It was also recently applied to eleven coastal wetlands in North Africa, El Mahrad et al. (2020). The focus is on direct pressures that result from human activities (Elliott and Whitfield, 2011) and follows the typology proposed by Elliott et al. (2014).

The article focuses on Activities-Pressures-State-Impact and these are bolded in the text rather than sub-dividing the sections. The article also considers the effect of the change in state of the environment and the wetland ecosystem on the delivery of ecosystem services (ES). Ecosystem services provide an important link between the state of the natural system and human welfare. The are the answer to the questions 'so what'? 'why is this important'? In this review, we used the Millennium Ecosystem Assessment [MEA] (2005) classification of ecosystem services. There are more recent classifications of ecosystem services but the Millennium Ecosystem Assessment [MEA] (2005) is still widely used by international organizations, and there remain challenges to the valuation of ecosystem services in coastal wetlands (Newton et al., 2018).

At the end of each section, we have also included some brief comments about indirect pressures. Indirect pressures, such as climate induced sea-level rise, are uncontestably important to coastal wetlands. However, they are not the focus of the current article and thus not discussed at length. They are especially important in the wetlands where local population and the direct pressures are low, such as the Mackenzie-Beaufort polar wetland and the Gulf of Papua.

\section{HUMAN ACTIVITIES AND ANTHROPOGENIC PRESSURES ON COASTAL WETLANDS}

\section{Polar Coastal Wetlands}

Arctic and Antarctic coasts have low human population densities. The development, structure, and land use of northern Polar coastal wetlands has been reviewed by Martini et al. (2019). The inhabitants still carry out some traditional activities but there is an increase in economic activities. A large proportion of small settlements on the polar coasts of Alaska, northern Canada, Greenland and parts of Russia have mixed cash and 


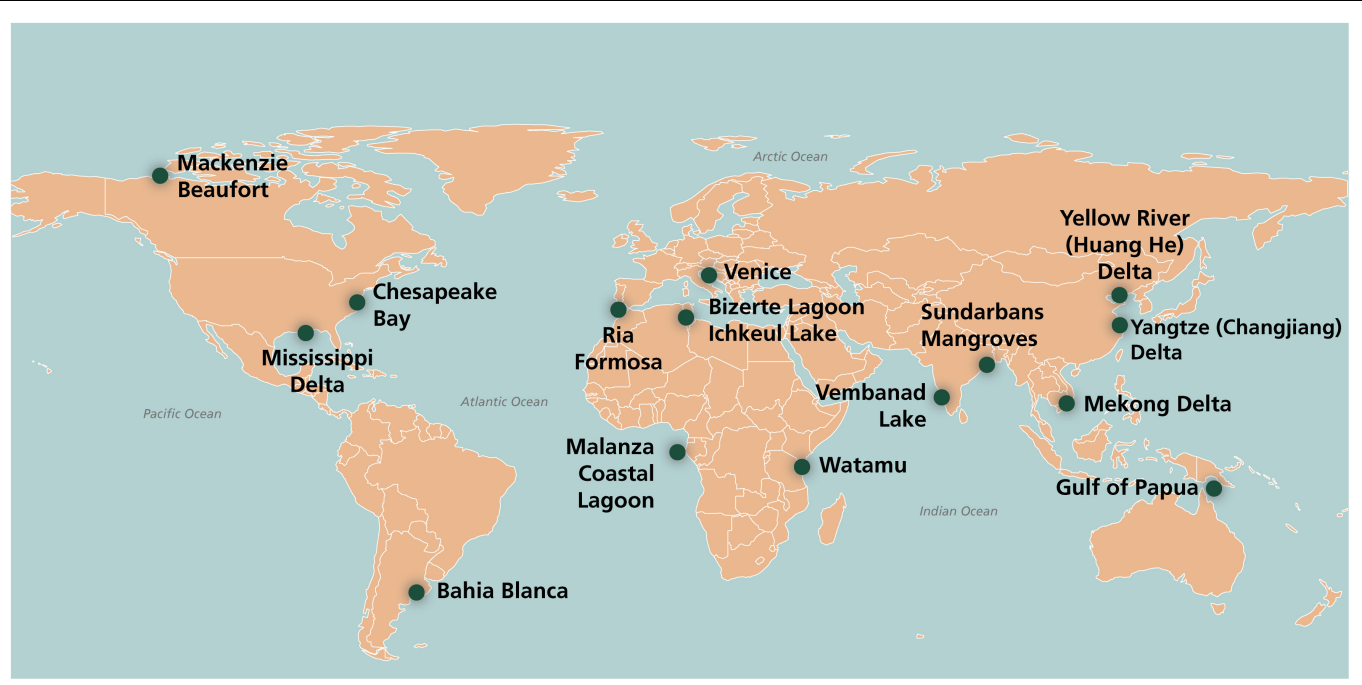

FIGURE 1 | Map showing location of the coastal wetlands in the text. (Credit: Dylan Taille).

subsistence economies, in contrast to northern Norway, Iceland, or large urban centers such as Murmansk (Jungsberg et al., 2019). Regions where economic activities are more developed have more extensive industrial infrastructure, such as the Prudhoe Bay oilfield on the Alaskan North Slope (Walker and Peirce, 2015). Past activities, such as dumping of mine tailings or encasement of drilling muds in permafrost, may still exert pressures on coastal wetlands, decades after the activity has stopped (Thienpont et al., 2013).

The low populations result in relatively low or localized anthropogenic, direct pressures on coastal wetlands. The loss of sea ice and resulting rapid increase in navigation along Arctic coasts will increase pressures from shipping, tourism, commercial fishing, hydrocarbon exploration and extraction, and mining activities. Economic investment from globalization has stimulated human activities and pressures that are increasing environmental state changes, with progressive reduction of sea ice, degradation of permafrost (Forbes, 2011). Many polar coastal wetlands exhibit relatively rapid state changes attributed to global and regional climate warming (Forbes and Hansom, 2011).

Where traditional activities remain important, e.g., subsistence harvesting, loss of ecosystem services may translate to impacts on welfare, food insecurity and affect cultural integrity, health, and wellbeing.

The negative effects may be magnified in the future because of indirect pressures that cause changes in key environmental variables, e.g., temperature, $\mathrm{pH}$, and redox potential (Kokelj et al., 2010; Barkay et al., 2011; Grosse et al., 2016).

\section{Mackenzie-Beaufort Coastal Wetland, Canada}

The Mackenzie Delta covers an area of 13,000 $\mathrm{km}^{2}$ $(\sim 60 \mathrm{~km} \times \sim 200 \mathrm{~km})$ in the southeastern Beaufort Sea, on the western Arctic coast of Canada (Forbes, 2019). The Arctic tree-line bisects the delta, the southern part of which is forested. Slightly over $50 \%$ of the delta plain is occupied by sedge wetlands, channels, and over 49,000 lakes (Emmerton et al., 2007). Permafrost extends to about $60 \mathrm{~m}$ depth in Holocene delta sediments, with many thaw taliks beneath lakes or channels that do not freeze completely in winter (Todd and Dallimore, 1998). There is higher ground to the east and west of the outer delta, with permafrost extending to a depth of 500-700 m. Erosional breaching of thaw lake basins has created a highly indented coast with eroding bluff headlands, local dunes, low spits and barrier islands, and shallow estuaries with supratidal Puccinellia phryganodes flats and accumulations of driftwood from the Mackenzie River (Ruz et al., 1992; Forbes and Hansom, 2011; Forbes et al., 2014). The delta is micro-tidal (range $<0.5 \mathrm{~m}$ ), but storm surges of up to $2.5 \mathrm{~m}$ cause extensive flooding (Manson and Solomon, 2007; Lamoureux et al., 2015).

The human population in the region is small (Kokelj et al., 2012), consisting of the regional administrative, industrial, and transportation hub of Inuvik (2015 pop. 3265, 68\% indigenous), the smaller delta settlement of Aklavik (2015 pop. 668, 94\% indigenous), and the outer-coast community of Tuktoyaktuk (2015 pop. $965,89 \%$ indigenous).

Some human activities are seasonal and intermittent, such as the extensive occupation of hunting and fishing camps throughout the delta and at seasonal traditional settlements along the outer coast (Lamoureux et al., 2015). Human activities of the Inuvialuit (western Arctic Inuit) and Gwich'in people include subsistence hunting and fishing as well as administration and public services. Land and resource uses are co-managed with federal and territorial government agencies under the Inuvialuit Final Agreement 1984, the Gwich'in Land Claim Settlement Act 1992, and fisheries and game co-management bodies. Subsistence food harvesting and hunting activities in the Inuvialuit Settlement Region includes berries, medicinal plants, fish including cisco (Coregonus spp.) and char (Salvelinus spp.), birds (especially geese and ducks), and mammals such as polar bear, caribou, moose, muskrat, beluga whale, bearded and ringed seal (Stephenson, 2004). 
TABLE 1 | List of coastal wetlands used as examples in this article, with some of the descriptors.

\begin{tabular}{|c|c|c|c|c|c|c|c|c|}
\hline $\begin{array}{l}\text { Name of coastal } \\
\text { wetland }\end{array}$ & $\begin{array}{l}\text { Adjacent } \\
\text { sea/Ocean }\end{array}$ & $\begin{array}{l}\text { Continent and } \\
\text { country (ies) }\end{array}$ & Latitudinal & $\begin{array}{l}\text { Geomorphological } \\
\text { type }\end{array}$ & Habitats & Protection/conservation & Area $\mathbf{k m}^{2}$ & $\begin{array}{l}\text { Human } \\
\text { population }\end{array}$ \\
\hline Bahia Blanca & South West Atlantic & $\begin{array}{l}\text { South America, } \\
\text { Argentina }\end{array}$ & Temperate & $\begin{array}{l}\text { Coastal plain } \\
\text { estuary }\end{array}$ & Tidalflats, Saltmarsh & $\begin{array}{l}\text { Provincial and municipal } \\
\text { reserves, }{ }^{1} \text { WHSB Reserve }\end{array}$ & 3,000 & 440,000 \\
\hline Chesapeake Bay & Atlantic Ocean & North America & Temperate & Estuary & Saltmarsh, Tidal wetlands & $\begin{array}{l}{ }^{2} \mathrm{CBP}, \text { Alliance for the Bay, } \\
\text { CBF, River keepers }\end{array}$ & 1,141 & $17,700,000$ \\
\hline Bizerte Lagoon & Mediterranean Sea & North Africa, Tunisia & Semi-arid climate & Coastal lagoon & $\begin{array}{l}\text { Seagrass meadow } \\
\text { Micro-marshes Sandy } \\
\text { coasts Mudflats }\end{array}$ & & 128 & $\begin{array}{l}568,000 \text { (all around } \\
\text { lagoon) }\end{array}$ \\
\hline Ichkeul Lake & Mediterranean Sea & North Africa, Tunisia & Semi-arid climate & Coastal lake & Marshes Reed beds & $\begin{array}{l}\text { Biosphere reserve, } \\
{ }^{3} \text { UNESCO World Heritage } \\
\text { Site, }{ }^{4} \text { Ramsar Site, National } \\
\text { Park }\end{array}$ & 120 & $\begin{array}{l}350 \text { (in biosphere } \\
\text { reserve) }\end{array}$ \\
\hline $\begin{array}{l}\text { Mekong Delta } \\
\text { wetlands }\end{array}$ & $\begin{array}{l}\text { South China Sea, } \\
\text { Vietnamese East } \\
\text { Sea }\end{array}$ & Asia, Vietnam & Subtropical & $\begin{array}{l}\text { Coastal alluvial river } \\
\text { delta }\end{array}$ & $\begin{array}{l}\text { Saltmarsh, Mangroves, } \\
\text { Mudflats, Grassy wetlands, } \\
\text { Controlled rice paddies }\end{array}$ & Several nature reserves & 40,600 & $18,000,000$ \\
\hline Mississippi delta & $\begin{array}{l}\text { North West } \\
\text { Atlantic, Gulf of } \\
\text { Mexico }\end{array}$ & $\begin{array}{l}\text { North America, } \\
\text { United States }\end{array}$ & Temperate & $\begin{array}{l}\text { Delta and deltaic } \\
\text { plain }\end{array}$ & $\begin{array}{l}\text { Tidal flats, Fresh to } \\
\text { Saltmarsh }\end{array}$ & State of Louisiana & 17,417 & $2,000,000$ \\
\hline $\begin{array}{l}\text { Mackenzie- } \\
\text { Beaufort }\end{array}$ & Arctic Ocean & $\begin{array}{l}\text { North America, } \\
\text { Canada }\end{array}$ & $\begin{array}{l}\text { Low-Arctic } \\
\left(68-70^{\circ} \mathrm{N}\right)\end{array}$ & $\begin{array}{l}\text { Delta, Coastal } \\
\text { embayments }\end{array}$ & $\begin{array}{l}\text { Delta plain, Supratidal } \\
\text { marsh, Inundated tundra, } \\
\text { Estuary }\end{array}$ & $\begin{array}{l}\text { Migratory bird sanctuary } \\
\text { (federal), co-management } \\
\text { regime }\end{array}$ & 13,000 & 4,900 \\
\hline $\begin{array}{l}\text { Malanza coastal } \\
\text { lagoon }\end{array}$ & South East Atlantic & $\begin{array}{l}\text { Africa, São Tomé } \\
\text { and Principe }\end{array}$ & Tropical & Coastal lagoon & Mangroves Mudflats & Obô Natural park & 0.7 & 1,000 \\
\hline $\begin{array}{l}\text { Gulf of Papua } \\
\text { mangroves }\end{array}$ & Coral Sea, Pacific & $\begin{array}{l}\text { Australasia, } \\
\text { Papua New Guinea }\end{array}$ & Tropical & Delta complex & Mangroves & & 3,780 & 107,000 \\
\hline Ria Formosa & North East Atlantic & $\begin{array}{l}\text { Europe, (SW), } \\
\text { Portugal }\end{array}$ & Temperate & Coastal lagoon & $\begin{array}{l}\text { Seagrass, Saltmarsh, } \\
\text { Dunes, Mudflats }\end{array}$ & $\begin{array}{l}\text { Ramsar Site, Natura (EU), } \\
\text { National Park }\end{array}$ & 80 & $\begin{array}{l}135,500 \text { (3main } \\
\text { towns) }\end{array}$ \\
\hline $\begin{array}{l}\text { Sundarbans } \\
\text { mangroves }\end{array}$ & $\begin{array}{l}\text { Indian Ocean, Bay } \\
\text { of Bengal }\end{array}$ & $\begin{array}{l}\text { Asia (S) } \\
\text { Bangladesh, India }\end{array}$ & Sub-Tropical & Delta & Mangroves & $\begin{array}{l}\text { Ramsar Site, UNESCO } \\
\text { World Heritage Site }\end{array}$ & 10,000 & $3,500,000$ \\
\hline Vembanad Lake & $\begin{array}{l}\text { Arabian Sea, Indian } \\
\text { Ocean }\end{array}$ & Asia (S), India (W) & Tropical & Coastal lagoon & $\begin{array}{l}\text { Mangroves, Marsh, } \\
\text { Backwater, Estuary }\end{array}$ & $\begin{array}{l}\text { Ramsar Site, Bird sanctuary } \\
\text { under }{ }^{5} \text { WLPA }\end{array}$ & 1,521 & $1,676,560$ \\
\hline Venice & $\begin{array}{l}\text { Adriatic, } \\
\text { Mediterranean Sea }\end{array}$ & Europe (S), Italy & Temperate & Coastal lagoon & $\begin{array}{l}\text { Seagrass, Saltmarsh, } \\
\text { Subtidal and intertidal } \\
\text { Mudflats }\end{array}$ & Ramsar Site (Valle Averto) & 550 & $\begin{array}{l}85,000 \text { (Venice } \\
\text { municipality only) }\end{array}$ \\
\hline $\begin{array}{l}\text { Watamu, Mida } \\
\text { Creek }\end{array}$ & Indian Ocean & Africa $(\mathrm{E})$, Kenya & Tropical & Coastal creek & $\begin{array}{l}\text { Mangroves, Mudflats, Coral } \\
\text { reef }\end{array}$ & $\begin{array}{l}\text { UNESCO Biosphere } \\
\text { reserve; National Reserve }\end{array}$ & 32 & $\begin{array}{l}57,200 \text { (3main } \\
\text { towns) }\end{array}$ \\
\hline $\begin{array}{l}\text { Yangtze } \\
\text { (Changjiang) Delta }\end{array}$ & East China Sea & Asia $(E)$, China $(E)$ & Temperate & Delta & Saltmarsh, Mudflats & $\begin{array}{l}\text { Ramsar Site, } 5 \text { nature } \\
\text { reserves }\end{array}$ & 350 & $1,000,000,000$ \\
\hline $\begin{array}{l}\text { Yellow River (Huang } \\
\text { He) Delta }\end{array}$ & Bohai Sea & Asia (E), China (NE) & Temperate & Delta & $\begin{array}{l}\text { Saltmarsh, Mudflats, } \\
\text { Seagrass, Dunes }\end{array}$ & $\begin{array}{l}\text { Ramsar Site, Shandong } \\
\text { Province reserve, National } \\
\text { Reserve }\end{array}$ & 18,000 & $5,200,000$ \\
\hline
\end{tabular}

${ }^{1}$ WHSBR, Western Hemisphere Shore Bird Reserve; ${ }^{2}$ CBP, Chesapeake Bay Programme; ${ }^{3}$ UNESCO, United Nations Educational, Scientific and Cultural Organization; ${ }^{4}$ Ramsar, Convention on Wetlands; ${ }^{5}$ WPLA, Wildlife Protection Area. 
Human activities related to economic development in the wetland region include infrastructure development, such as construction of Distant Early Warning (DEW) line sites in the 1950s; establishment of the planned community of Inuvik in 1953-1960 to replace flood-prone Aklavik; roads, airports, and port facilities; fuel storage, electric generation and distribution infrastructure; freshwater and waste management systems; hydrocarbon exploration and production installations (well sites, mud sumps, other waste dumps, and camps); seismic cut-lines and degraded artificial islands on the inner shelf (Lamoureux et al., 2015). Road access to Aklavik (and until 2017 to Tuktoyaktuk) has been by winter ice road on delta channels, but the ice season is shortened by climate warming (Lesack et al., 2014; Lamoureux et al., 2015). Tuktoyaktuk is a regional shipping hub for remote community sea-lift operations and offshore hydrocarbon exploration activities. Artificial shore protection at Tuktoyaktuk has been partially successful at limiting erosion. There has been dredging in harbour approaches and to build artificial islands for drilling. Future activities such as infrastructure development, new travel routes, and growing tourism opportunities may impact cultural sites (Irrgang et al., 2019).

Direct pressures related to activities such as oil and gas exploration have ended with increased supply of low-cost natural gas. Oil exploration on the shelf and offshore supply activities in Tuktoyaktuk have also been suspended (Byers, 2016). These past activities still exert pressures on the environment. Contaminated hydrocarbon exploration waste, such as drilling fluids, was placed in sumps to be contained in permafrost. However, about $50 \%$ of legacy drilling mud and camp sumps in the delta have collapsed due to warmer temperatures (Kokelj and GeoNorth Limited, 2002).

These pressures affect the state of the environment. Dredging for artificial island construction in the past disturbed the state of the benthic habitat, but ubiquitous and perennial seabed scouring by ice causes more disturbance (Blasco et al., 2013). The changes in the state of the environment result in a loss of ecosystem services. The Mackenzie Delta and Kendall Island Bird Sanctuary are of international importance for the large numbers of migratory birds - particularly shorebirds, cranes, swans, geese, and ducks - that depend on the extensive staging and breeding habitat. The wetlands also provide critical habitat for fish and other wildlife. Regional (glacial-isostatic) and local (compaction) subsidence combined with climate-driven rising sea level causes the gradual inundation of outer-delta avian breeding habitat and low-lying tundra along the coast (Lamoureux et al., 2015; Forbes, 2019), and accelerating erosional retreat of the delta front and adjacent coast, increasing carbon inputs to the Arctic Ocean (Fritz et al., 2017; Couture et al., 2018; Tanski et al., 2019). The Tarium Niryutait Marine Protected Area was established in 2010 in three areas totaling $1,800 \mathrm{~km}^{2}$ of the outer Mackenzie Delta and estuary. One of the objectives was the conservation of one of the largest summering stocks of beluga whale (Delphinapterus leucas), anadromous fish, waterfowl, and their habitat. This preserves provisioning and cultural services as well as indigenous harvesting traditions ${ }^{1}$.

Loss of ecosystem services and localized contamination have negatively impacted the welfare of subsistence-dependent residents, with implications for community and household health and food security (Wesche and Chan, 2010). The leaching of contaminants, especially hydrocarbons, into the surrounding soil and groundwater has caused localized contamination of the wetlands, raising health concerns due to extensive fish consumption and impacts on human welfare.

Indirect pressures resulting from global emissions and climate change have much greater consequences in the MackenzieBeaufort region than direct pressures. These indirect pressures include: accelerated sea-level rise; reduced sea ice, increased open water in the Beaufort Sea; increased wave energy with expanded open-water fetch; increased frequency and reach of storm surges; and accelerated coastal erosion; reduced snowfall; earlier and more rapid ice breakup in the Mackenzie delta; lower peak water levels and reduced off-channel flooding in the delta; rising temperatures contributing to thaw subsidence; accelerated coastal erosion, and ecological change (Manson and Solomon, 2007; Barber et al., 2008; Burn and Kokelj, 2009; Lesack et al., 2013; Vermaire et al., 2013; Obu et al., 2016; Forbes, 2019).

\section{Coastal Wetlands in North America (Excluding Arctic) Chesapeake Bay Wetlands, United States}

The Chesapeake Bay is a $320 \mathrm{~km}$ long, shallow, north-south estuary surrounded by the states of Maryland and Virginia on the east coast of the United States. Major tributaries supply freshwater to the bay, including the Susquehanna that supplies more than $50 \%$ of the freshwater, the Patuxent, Potomac, York, and James rivers. There were approximately 114,100 ha of tidal wetlands, consisting of saltmarsh and tidal fresh and saltwater wetlands in 2010, almost 37,200 ha of Submerged Aquatic Vegetation (SAV) in 2012, primarily eelgrass (Zostera marina) and widgeon grass (Ruppia maritima) (Chesapeake Bay Program [CBP], 2012).

The watershed is large, approximately $165,760 \mathrm{~km}^{2}$, including both heavily urbanized areas in and around the major cities, as well as large portions of distinctly rural, agricultural lands. It includes almost all the state of Maryland, and parts of Virginia, West Virginia, Delaware, Pennsylvania, and New York. Major cities include Washington DC, Baltimore, Richmond, Norfolk, and Harrisburg. The total watershed population is approximately 17.7 million people, (2012 census), expected to grow to 20 million by 2030 . The increased spread of urban areas is expected to continue with population growth.

Human activities in the watershed that exert pressures on the Chesapeake wetlands include agriculture, land-use changes, shoreline modification and introduction of non-indigenous species. The watershed includes many thriving economic sectors such as sales, services, construction, manufacturing, government, agriculture and use of natural resources (McKendry, 2009). Activities such as hardening of shorelines are now strictly

\footnotetext{
${ }^{1}$ https://laws-lois.justice.gc.ca/PDF/SOR-2010-190.pdf
} 
regulated. Nevertheless, existing shoreline modification and intense development along the shoreline can lead to wetland loss or prevent new wetlands from forming, blocking the migration of wetlands to upland areas as sea levels rise (Torio and Chmura, 2013; Raposa et al., 2016), a synergy of direct and indirect pressures.

A complex mixture of direct pressures result from intensive land-use and the introduction of invasive species. Nutria (Myocastor coypus, a South American rodent) was introduced in the late 1960s and displaced native species such as beaver, muskrat and otter. Nutria thrived on native marsh grasses, damaging thousands of hectares of wetland through destructive feeding (National Fish and Wildlife Service, 2016). In addition, the invasive common reed, Phragmites australis, grows rapidly to outcompete other wetland vegetation, such as native grasses (Chesapeake Bay Program [CBP], 2012). However, the main direct pressures to the overall condition of Chesapeake wetlands are now nutrient and sediments from intensive land-use, urban wastewater and atmospheric deposition of nitrogen (Zhang et al., 2015).

Pressures from intense land use activities directly and indirectly affects the state of Chesapeake wetlands. Excess nutrients result in areas of low dissolved oxygen and reduced water clarity (Kemp et al., 2005). This has affected the state of the submerged aquatic vegetation (SAV), and habitat for commercial species, including oysters (Crassostrea virginica), crabs (Callinectes sapidus), and bass (Morone saxatilis). Fishing pressure has also contributed to the decline in the state of these important species and may mask the signal from eutrophication effect (Kemp et al., 2005). Sediment inputs affect the benthic state, cover hard-bottom habitat, smother oyster reefs, increase turbidity, reducing light available for SAV (Lefcheck et al., 2017). Lefcheck et al. (2017) document a change of state, a 29\% decline in eelgrass area from 1991 to 2016, primarily from decreasing water clarity increases and water temperature. Despite this degradation of the state, management measures to reduce nutrient pressures can increase SAV growth and area (Lefcheck et al., 2018). This is a positive sign that the state of ecosystems may recover after humans alleviate pressures put on sensitive habitats like SAV (Lefcheck et al., 2018).

Loss of ecosystem services include a decrease of Chesapeake wetland habitat for economically valuable species of fish and crabs, both of which are cultural keystones in the Chesapeake region (Paolisso, 2008). There is also a loss of storm surge mitigation, filtration of sediments and nutrients from urban and agricultural stormwater runoff, sequestration of organic carbon and opportunities for recreation (Costanza et al., 1989; Millennium Ecosystem Assessment [MEA], 2005). Tidal marshes are carbon, nutrient and sediment sinks, so the degradation of their state increases pressures from nutrient and sediment fluxes to Chesapeake Bay (Kemp et al., 2005).

The main indirect pressure on the Chesapeake wetland is from sea-level rise. Wetlands and marshes can increase elevation in response to indirect pressures, such as sea level rise, under favorable conditions of sediment supply, root growth, and litterfall (Becket et al., 2016). Mean sea level rise in Chesapeake
Bay ranged from $2.7-4.5 \mathrm{~mm} \mathrm{y}^{-1}$ from 1950 to 2000 , faster than the global mean of $1.8 \mathrm{~mm} \mathrm{y}^{-1}$, probably due to land subsidence. Predicted future rates of sea-level rise (about $6 \mathrm{~mm} \mathrm{y}^{-1}$ ) will increase marsh loss rates and area (Cahoon, 2007), as sea levels are expected to rise by $0.4-1.6 \mathrm{~m}$ by 2100 (Rybicki and Landwehr, 2007; Najjar et al., 2010). In a conservative scenario of $60 \mathrm{~cm}$ sealevel rise by $2100,65,000$ ha of coastal marsh would be converted to brackish marsh and 11,735 ha of tidal swamp to saltmarsh or open water, which is less diverse. Chesapeake wetlands at risk from sea-level rise include Blackwater Wildlife Refuge, Tangier Sound, and Virginia's Eastern Shore. Shifts in salinity will make the current marshes more favorable for certain species and less for others (Najjar et al., 2010).

\section{Mississippi River Delta Coastal Wetlands, United States}

The Mississippi River, the largest in North America, meanders across the coastline every 700-1,200 years, seeking the hydrologic path of least resistance to the sea. These cycles of delta growth and decay (Frazier, 1967) created $17,417 \mathrm{~km}^{2}$ of fresh to salt marshes in a micro-tidal regime, which represent $41 \%$ of the United States coastal wetlands. The soils alongside the main channel wetlands are mostly comprised of inorganic matter, and hurricanes deposit a considerable return flow of inorganics to the fringing coast (Tweel and Turner, 2014). In contrast, the wetland soils between the distributary levees are organic-rich. The rates of land loss rose in the 1930s, peaked in the between 1965 and $1986\left(126 \mathrm{~km}^{2}\right.$ $\mathrm{y}^{-1} ; 0.07 \% \mathrm{y}^{-1}$ ) and the current rates are near zero (Couvillion et al., 2017). The cumulative losses in the last 100 years are about $25 \%$ of the original amount, but are expected to increase with the rate of sea-level rise (Strauss, 2013; Church et al., 2014). These losses are well-publicized through media campaigns to acquire restoration funding.

New Orleans is the main urban area and population center, (population 393,000 in 2017). New Orleans is vulnerable to natural disasters because it is built on land of low elevation, in an area of relatively frequent hurricanes as well as storm surges, and it has a weak evacuation strategy (Turner, 2007). There are multiple human activities by the approximately 2 million people who live in the twelve coastal parishes of the Mississippi River delta, such as: fishing, shellfish (e.g., oysters) and aquaculture (e.g., catfish); poultry rearing; agriculture (cotton, sugar, rice, corn, and soybean); oil and gas; shipping and ports; recreation (hunting, fishing, and tourism).

Anthropogenic pressures are well-documented. Sediment fluxes to the coastal zone have varied in the last 200 years. River-mouth wetlands expanded in the 1800s, when trees in the watershed were cut and soils were plowed, enhancing sediment delivery to the coastal zone (Turner and Rabalais, 2003; Tweel and Turner, 2012). Implementation of soil conservation measures trapped sediments behind dams, which decreased sediment loads after the 1930s. River-mouth wetland areas receded dramatically and are now close to the 1700 s area (Turner, 2017). The dredging of canals for navigation and drilling for oil-gas exploration have left spoil banks of dredged material as a continuous, $20,000 \mathrm{~km}$ long levee that reaches $1-2 \mathrm{~m}$ in wetlands where the tidal range is only $20-30 \mathrm{~cm}$. This presents 
a barrier to tidal water flowing in and out of wetlands, so canal density is directly related to land loss rates from 1900s to present throughout the deltaic plain (Turner and McClenachan, 2018). The Deepwater Horizon oil spill in 2010 released 5 million barrels of oil in 2010 with a surface slick covering $149,000 \mathrm{~km}^{2}$ of the Gulf of Mexico and oiling coastal marshes for decades (Turner et al., 2019). The nutrient pressure from the Mississippi River watershed has increased nitrogen and phosphorous loads in the last 100 years (Turner and Rabalais, 2003). This is a much greater nutrient pressure than the sewage and local runoff.

These pressures affect the state of the Mississippi wetlands. The contaminated sediments from the Deepwater Horizon oil spill (Rabalais and Turner, 2016) degraded the salt marsh vegetation, decreasing the cover of living marsh vegetation, covering and killing marsh fauna. Marsh shoreline erosion was 2.5 times higher after oiling and the marsh will not recover (Turner et al., 2016). Diversions of the Mississippi water to deltaic wetlands for restoration (a point-source) or cultural eutrophication (non-point source) increase the availability of nitrogen and phosphorous to the wetlands, contributing to general eutrophication of the delta, which also affects the state of the soils and causes carbon losses (Darby and Turner, 2008; Kearney et al., 2011; Deegan et al., 2012; Bulseco et al., 2019).

The delivery of ecosystem services is affected by the degradation of the wetland. This includes regulating services, such as protection from hurricanes, by increasing resistance and lowering storm surge height. The reduction in storm-surge height is $\sim 0.3 \mathrm{~m}$ per $1-2 \mathrm{~km}$ of wetland and the presence of vegetation is especially important (Barbier et al., 2008; Costanza et al., 2008; Gedan et al., 2011; Shepard et al., 2011). This contributes to the protection and restoration of coastal areas, which costs $\$ 50$ billion in Louisiana (Coastal Protection Restoration Authority [CPRA], 2017). Furthermore, the wetland provides an important fish and shrimp habitat for juveniles (Turner, 1977) that become $25-35 \%$ of the United States commercial fish landings value and tonnage.

The loss of these ecosystem services can impact human welfare, including loss of life, public infrastructure and private property. A third (36\%) of the land in the United States that is less than $3.5 \mathrm{~m}$ elevation is in coastal Louisiana and the height of a Category 3 storm-surge is at least $3 \mathrm{~m}$. The slope (elevation gradient) is gradual and sediment supply has been reduced by flood protection levees. New Orleans is a 'city below sea level' in this vulnerable zone, seaward of the edge of the upland. Water does not drain out naturally when it rains but must be pumped out uphill. Urban expansion and construction consolidate and compact the fine-grained and highly organic sediments, squeezing out the water and resulting in soil subsidence. The structural integrity of foundations, levees, gas lines and roads are affected by the slow changes in soil oxidation, drainage, volume, settling and subsidence.

Future indirect pressures from sea level rise (SLR) rates will affect the vulnerability and sustainability of river deltas. The Mississippi delta formation began when SLR slowed about 8,000 years ago to around $5 \mathrm{~mm} \mathrm{y}^{-1}$ or less (Turner and Rabalais, 2018; Turner et al., 2018). The rates were $5.6 \mathrm{~mm} \mathrm{y}^{-1}$ from 1996 to 2016, which is at the limit of vertical accretion (Morris et al., 2016). Future estimates of SLR vary from an intermediate low rate of $5.6 \mathrm{~mm} \mathrm{y}^{-1}$ to a high rate of $16 \mathrm{~mm}$ $\mathrm{y}^{-1}$ (National Research Council [NRC], 2010), reaching 8$16 \mathrm{~mm} \mathrm{y}^{-1}$ by 2080-2100 (Church et al., 2014). The Mississippi River delta has been sustained and protected by substantial, compensating infrastructure and by multiple, short-term and energy-intensive strategies. This has lowered its vulnerability to risks and raised its sustainability relative to other deltas (Tessler et al., 2015). However, such energy-intensive interventions will become more expensive and less sustainable in a more energyconstrained future scenario. Sustaining the delta in the future will require long-term policies to develop, sustainability solutions (Tessler et al., 2015).

\section{Coastal Wetlands in South America Bahia Blanca Wetlands, Argentina}

The Bahia Blanca is a temperate and mesotidal coastal wetland located in southwest of Buenos Aires Province, Argentina. Despite its size, most of the estuary is marine dominated (Perillo, 1995), with very little river input (Piccolo and Perillo, 1990; Perillo and Piccolo, 2020). The extensive coastal wetland is roughly triangular, about $90 \mathrm{~km}$ in length and $53 \mathrm{~km}$ wide at the mouth, about $3,000 \mathrm{~km}^{2}$, cut by NW-SE tidal channels and islands (Perillo and Piccolo, 1999, 2020). Large areas of tidal flats, as well as Spartina and Salicornia marshes, have developed, providing conditions for a rich benthic infauna that supports significant artisanal fisheries. This wetland includes both a provincial natural reserve that includes the whole estuary south of the Canal Principal and a municipal reserve of only $3 \mathrm{~km}^{2}$, SW of the city of Bahia Blanca (Perillo and Iribarne, 2003a,b). The wetland is part of the Western Hemisphere Shorebird Reserve Network since March 2016. To the north of Canal Principal, there are two major cities, Bahía Blanca, population 350,000, and Punta Alta, population 70,000, as well as several small towns, such as Villa del Mar, Ingeniero White and General Cerri. The total population around the wetland was estimated at 440,000 in 2016. There is no direct access or settlements on other parts of the wetland.

There are many important human activities in and around the wetland. The main economic sector is maritime transport and shipping, with construction and maintenance of port facilities providing one of the major activities. The largest and deepest harbor system in Argentina is on the coast of the Canal Principal, that exports industrial products and grain. There are oil transfer buoys in the harbors, a trading dock at the port of Rosales and a navy base at Puerto Belgrano. There are two ports further in the estuary, Ingeniero White that has an area devoted to grain and another for general merchandise (i.e., oil, containers, and petrochemical products), and Puerto Galván for oil and petrochemical products (Zilio et al., 2013).

Dredging is a significant human activity that keeps the port facilities accessible to large ships. The navigation channel was dredged to deepen it from 10 to $13.5 \mathrm{~m}$ during 1989-1991, which facilitated the development of one of the most important petrochemical complexes in Argentina (Zilio et al., 2013). The navigation channel was further deepened to $15 \mathrm{~m}$ depth at low tide during 2012-2014. Additionally, there is dredging of 
the piers for maintenance purposes. The port authorities are planning to further develop harbor facilities and the installation of new industries planned for 2020. Furthermore, the wetland is used for sewage disposal (Speake et al., 2020).

These activities exert anthropogenic pressures on the wetland along the northern coast of the Canal Principal. Pressures include pollution, harbor, and industrial development. The major Urban Waste-Water Treatment is not working properly and there are four untreated discharges of sewage into the wetland, two from Bahía Blanca City, one for Punta Alta City, and one for the navy base. Pollution is mainly due to sewage discharges, with minor industrial pollution from the industrial flares and deposition of airborne contaminants. These include Salmonella and Escherichia from sewage discharge and metals from industrial discharges (Simonetti et al., 2017; Severini et al., 2018). The material from the dredging has covered many tidal flats and marshes along the Canal Principal, in some cases forming new islands where the port authorities are planning to develop future harbor facilities.

These pressures have affected the state of the wetland environment and ecosystem. The estuary is eutrophic from the pressures of nutrients from untreated discharges (Freije et al., 2008) that may result in widespread eutrophication, if the flushing capacity of the estuary is exceeded. Nevertheless, pollution is low at present because of the strong currents and rapid mixing of the water in the Canal Principal (Botté et al., 2007). The disposal of dredged materials has affected the most important nesting area of the Olrog's Gull (Larus atlanticus), which is an endangered species native of Argentina, Uruguay, and Brazil, of which $2 / 3$ of the total population lives in the Bahia Blanca wetland.

This degradation of the state of the wetland environment and ecosystem leads to a loss of ecosystem services. The long-term effects of sewage pollution could be damaging to the regulating services of the wetland such as denitrification. Meanwhile, there is a decrease in the provisioning services of the wetland, i.e., the catch of prawns, shrimp and local fish. Nevertheless, there is little evidence at present that this reduction can be directly associated to pollution rather than large scale effects, such as Southern Oscillation events, especially during dry La Niña periods. However, artisanal fishers complain of the deformations of fish caught in the vicinity of effluent discharges and there maybe impacts on human welfare (Speake et al., 2020).

There are also indirect pressures from climate change. The islands in the wetland ecosystem are only $50 \mathrm{~cm}$ above spring high water levels. Mean sea level rise for Argentina is on the order of $1.6 \mathrm{~mm} \mathrm{y}^{-1}$ (Lanfredi et al., 1988). However, the estimated global increase of about $83 \mathrm{~cm}$ by year 2,100 (Oppenheimer et al., 2019) would completely flood the estuary (Perillo and Piccolo, 2020), and overwhelm the wetland and islands. There is no practical way to mitigate this situation. There also appears to be changes in the typical wind regime. These are strong winds from the $\mathrm{N}-\mathrm{NW}$ blowing about $40 \%$ of the time with average speeds of the order of $20 \mathrm{~km} \mathrm{~h}^{-1}$. These winds blow parallel to major channels affecting tidal prediction, navigation programming and the generation of large wind-tide interaction waves (Perillo and Sequeira, 1989; Perillo and Piccolo, 1991). However, in the last 5 years the number of calm days has increased significantly, which reduced the number of storm surge phenomena on the town of Ingeniero White from once a year to once every 2 or 2.5 years. That also changed the conditions in beaches just outside the estuary where there is a reduction of the appearance of jelly fishes (always associated to upwelling forced by $\mathrm{N}$ winds) during the summer months (Brendel et al., 2017).

\section{Coastal Wetlands in Europe}

Only two European case studies are presented in the text in order to reduce the length of the article. This is to provide examples of less well-known wetland systems, outside Europe. Nevertheless, some details of 12 further coastal wetlands in Europe are included in the supporting Supplementary Tables S1-S5. These European wetlands that are not represented in the text are shown in italics where they appear in a supporting table.

\section{Ria Formosa Wetland, Portugal}

The Ria Formosa wetland is part of a temperate, mesotidal, $80 \mathrm{~km}^{2}$ coastal lagoon, on the south coast of Portugal (Aníbal et al., 2019). The Gilão is the only permanent river flowing into the wetland that is connected to the Atlantic by several inlets. The wetland includes extensive areas of salt marsh (ArnaudFassetta et al., 2006) and seagrass meadows (Cabaço et al., 2009). There are three main towns in the catchment: Faro, the district capital $(\sim 64,500)$; Olhão $(\sim 45,000)$; and Tavira $(\sim 26,000)$, as well as several smaller urban areas (population data from 2011 Census, Instituto Nacional de Estatistica ${ }^{2}$ ). The influx of visitors in the summer increases the population, in some cases severalfold, overwhelming infrastructure designed for the resident population, such as Urban Waste-Water Treatment facilities (Newton et al., 2013; Cravo et al., 2015; Veríssimo et al., 2019).

Multiple human activities cause pressures on the Ria Formosa wetlands. These include change of land-use, such as conversion of saltmarsh into salt-extraction pans (salinas), a historical activity. Some of these ponds have now been converted for aquaculture of fish (Cunha et al., 2013), and others have been converted into Urban Waste-Water Treatment ponds, e.g., near the airport (Veríssimo et al., 2019). Construction in the three towns (Faro, Olhão, and Tavira) has encroached on the surrounding wetlands as well as on the sand dunes of the barrier islands that separate it from the Atlantic. Construction includes groin to retain sand along beaches to the west of the lagoon, the creation of consolidated inlets, such as Barra do Farol (Carrasco and Matias, 2019). An airport, a port (Faro) and several marinas (Faro, Olhão, and Tavira) have been constructed from the wetland. The wetland channels are regularly dredged for sediment extraction and to keep the access to the ports and marinas navigable, since the mean depth is only $1.5 \mathrm{~m}$. Several small, torrential streams (e.g., the Ribeira de São Lourenço and Gondra) were dammed with dykes to retain freshwater in the 19th Century, and some land was reclaimed from the wetland marshes for agriculture (e.g., Ludo). An artificial inlet, Nova Barra do Ancão, was opened in the western part of the lagoon in June 1997. Artisanal fishing and shellfish harvesting are important activities in the Ria Formosa and shellfish concessions are also in the wetland. Olhão is a

\footnotetext{
${ }^{2}$ https://www.ine.pt
} 
large fishing port, but most of the catch comes from the adjacent coastal waters rather than the lagoon. The Campina de Faro in the watershed is the richest agricultural region of the Algarve. Intensive farming includes water cress and salads (Vitacress), fruit and vegetables in greenhouses, as well as orange groves. Some agricultural land has been converted to golf (e.g., Quinta do Lago). There are also intensive poultry farms (Ludo) and pig-farms in the catchment of the wetland. The area around the Ria Formosa is not industrial, although there are some food industries, such as fish processing in Olhão.

The various human activities in the catchment of the Ria Formosa exert multiple anthropogenic pressures on the wetlands. Foremost of these is the loss of habitat and associated biodiversity, especially the loss of seagrass meadows and saltmarsh, as well as dunes. The groin, impoundments, ponds, obstructed channels and dykes, represent a loss of connectivity of the wetlands that disrupt both the hydrology and the sedimentology. This has resulted in a saline intrusion and salinization of the western part of the wetland, ever since the 19th century. Overfishing, shellfish harvesting, illegal harvesting of sea-cucumbers (Holothuria arguinensis) and the attempted introduction of non-indigenous species (Manila clam, Ruditapes philippinarum; Japanese prawn, Penaeus japonicus; Pacific oyster, Crassostrea gigas) are further pressures on the ecosystem. The use of fertilizers in the agricultural zone and golf-courses around the Ria Formosa, manure from animalrearing, and inadequate sewage treatment are all pressures that can lead to eutrophication (Newton et al., 2003) and microbial contamination (Cravo et al., 2015). Several studies have documented contamination and pollution of the Ria Formosa by metals and organic chemicals (Bebianno, 1997; Mudge and Duce, 2005; Bebianno et al., 2019; Moreira da Silva et al., 2019), despite the low industrial development around the wetland.

The deteriorating state of the environment and ecosystem has consequences on the ecosystem services provided by the Ria Formosa wetland (Newton et al., 2018). This has been most notable in the declining clam harvest (provisioning service). Decline in the coastal fisheries has also been attributed to the decline in seagrass (García-Marín et al., 2013) and nursery supporting services (Abecasis et al., 2009). The Ria Formosa is a popular destination for 'beach and sand' tourism (Zacarias et al., 2011; Semeoshenkova and Newton, 2015) as well as eco-tourism, thus contributing revenues to the local economy through cultural services. Perturbation of sediment fluxes and supply by construction on the dunes of the barrier islands, as well as the retention of sediment by dams in the catchment and groin to the west, make the wetland vulnerable to erosion (loss of regulating services) (Ceia et al., 2010) and storm surges. This threatens including important infrastructure, such as the international airport, thus potentially affecting tourism (cultural services).

The decline of ecosystem services has impacts on human welfare (Bebianno et al., 2019). Continued microbial contamination from sewage (Cravo et al., 2015) as well as algal toxins from HAB (Lage et al., 2014) and other public health issues (Bebianno et al., 2019) are related to the degradation of the wetland. The declining incomes of shellfish harvesters and artisanal fishers eventually make these culturally unique lifestyles unsustainable and fishers seek other sources of income and ultimately employment.

Like all coastal wetlands, the Ria Formosa is also threatened by indirect pressures such as sea-level rise and increased temperature (Brito et al., 2012), and storm surges. Violent Atlantic storms in recent years have frequently washed over the barrier islands (Almeida et al., 2012). So far, there has not been any loss of life, although infrastructure (airport) and housing has been affected by a tornado on 2011. These indirect pressures ultimately threaten the whole Ria Formosa wetland, which is constrained by urban development at its landward boundary.

\section{Venice Lagoon Wetlands, Italy}

The lagoon of Venice (Italy) is in the NW part of the Adriatic Sea and includes one of the largest Mediterranean wetlands. The lagoon is shallow (mean depth $1.5 \mathrm{~m}$ ) and covers about $550 \mathrm{~km}^{2}$, of which $432 \mathrm{~km}^{2}$ are tidal. The mean tidal amplitude is about $0.6 \mathrm{~m}$, with about $60 \%$ of water being renewed through three inlets every $12 \mathrm{~h}$ (Facca et al., 2014). Freshwater inputs are about $30 \mathrm{~m}^{3} \mathrm{~s}^{-1}$, delivered by small rivers and a network of artificial channels. The main rivers, Brenta and Sile, where diverted long ago in order to avoid the siltation of the lagoon (Solidoro et al., 2010).

Due to its complex morphology, the wetland includes subtidal flats, intertidal mudflats, saltmarshes, 'valli da pesca' (marginal areas close to tidal exchanges) and a network of relatively deep channels (Rova et al., 2015). Macroalgae and seagrasses account for most of the primary production. Besides the city of Venice, there are several small islands, such as Murano, Burano, Lido, S. Erasmo, which collectively host about 85,000 residents, according to Venice Municipality data. Venice and its lagoon are a highly attractive touristic venue and the numbers of visitors exceed the resident population.

Shipping and navigation, from small boat to large cruise ships, have always been important human activities for the islands of Venice lagoon, and tourism also increases the internal navigation. Shipping has entailed several modifications including rivers diversions and the construction of jetties at the inlets in the 19th and early 20th centuries. More recently, from 1927 to 1970, the navigation channels were dredged and enlarged for access to the main port facilities at Porto Marghera, which stimulated industrial development and activities around Mestre, affecting the wetlands. Clam dredging activities are now mostly illegal because of contamination. The catchment of the lagoon (Veneto) includes areas of market gardening, fruit-growing and vinegrowing reclaimed from the wetland. Groundwater extraction in the 1960's and 1970's was excessive and contributed to the subsidence of the wetland.

Resulting direct pressures include disruption of hydrology, re-suspension of large amounts of sediment that exacerbate the erosion of the wetland, increased nutrient and organic matter supply, as well as inputs of industrial effluents and contaminants to the wetland. Nutrient run-off from agriculture represents the main source of Nitrogen and nutrient pressure to the wetland. Poorly controlled shellfish harvesting, Manila clam 
(Ruditapes philippinarum), has increased sediment disturbance and resuspension in the wetland. Resuspension is exacerbated by increased internal navigation, mainly linked to tourism. Sediment resuspension can release contaminants that were trapped in the sediment as a legacy of industrial pollution in the 20th century, especially in the central part of the wetland (O'Higgins et al., 2014; Giubilato et al., 2016).

The state of the water and wetland sediment quality have been degraded by industrial activities that heavily contributed to the pollution of the lagoon in the past. Both sediment budget and sediment transport processes have been heavily affected by anthropogenic interventions. The disruption of hydrology and sediment supply has resulted in subsidence. Eutrophication can cause macrophyte blooms (Ulva), localized anoxia in confined areas of the lagoon wetlands and loss of seagrass, as in 2013. However, concentrations of inorganic nitrogen and phosphorus is decreasing in the water and at the sediment surface (Facca et al., 2014). The loss of wetland habitat, especially the reduction of seagrass meadows, saltmarshes and associated biodiversity, as well as the introduction of exotic, invasive algal species are severe. The area of saltmarshes has halved from 68 to $32 \mathrm{~km}^{2}$ between 1927 and 2002, while the area of subtidal flats has increased from 88 to $206 \mathrm{~km}^{2}$. Overall, the average depth of the lagoon has increased from $0.62 \mathrm{~m}$ in 1927 to $0.88 \mathrm{~m}$ in 2002 (Sarretta et al., 2009).

Ecosystem services provided by the Lagoon of Venice are still being assessed (Rova et al., 2015; Newton et al., 2018). Overfishing has led to sharp decrease in clam yield, from about 40,000 tons in the 1990 s to $2,000-5000$ tons in 2016. Seagrass meadows have recently recolonized large areas of southern subbasin, contributing to sediment bio-stabilization. Recolonization in the northern part is being stimulated by an EU funded LIFE project $^{3}$.

Indirect pressures such as sea level rise are expected to worsen due to climate change. Thus, the conservation of the wetland islands and protection from acqua alta flooding is one of the main current issues, with disastrous floods in November 2019. This has led to the major infrastructural changes to the inlets, e.g., the MOSES flood barrier.

\section{Coastal Wetlands in Africa}

A DPSIR analysis of coastal wetlands in North Africa includes 11 systems from south west Morocco to Egypt (El Mahrad et al., 2020). Thus, only one North African example is included in the present review, because of its unique characteristics as a 'double' system, the Bizerte-Ichkeul wetlands.

\section{Bizerte Lagoon and Ichkeul Lake Wetlands, Tunisia}

Bizerte lagoon and Ichkeul lake are linked, coastal wetlands in Tunisia, where the climate is Mediterranean, semi-arid, with a hot, dry summer and mild, wet winter (MAERH, 2003). Bizerte lagoon, also known as 'Lac de Bizerte' or 'Mezaouka', has an area of $128 \mathrm{~km}^{2}$ and a mean depth of $7 \mathrm{~m}$. A $6 \mathrm{~km}$ long inlet connects to the Mediterranean Sea and a $5 \mathrm{~km}$ long Tinja channel connects to Ichkeul lake (Béjaoui et al., 2008). Ichkeul is a

${ }^{3} \mathrm{http}: / /$ www.lifeseresto.eu/ brackish-freshwater lake with an annual depth variation of 1-3 m, low winter salinity $(S=3)$ and high summer salinity $(S=30-$ 50), (Savoure, 1977; Hollis, 1986; Ben Rejeb-Jenhani et al., 1991; Tamisier et al., 2000). Rainfall during autumn and winter flows in through 6 wadis, seasonal rivers, some overflowing through the Tinja channel into Bizerte lagoon. The reverse happens in summer, when high evaporation lowers the water level in Ichkeul lake and water flows in from Bizerte lagoon through the Tinja channel (Casagranda et al., 2006). The exceptional salinity gradient $(3-45)$ is a unique feature that gives Ichkeul lake and wetlands a rich biodiversity. The area comprises three units: the $89 \mathrm{~km}^{2}$ brackish water lake, $27 \mathrm{~km}^{2}$ marshes, and a $13 \mathrm{~km}^{2}$ isolated and wooded massif; Djebel Ichkeul (Trabelsi et al., 2012).

Few people (about 350 in 1999) work in the quarries and live in the Ichkeul reserve. Activities in the Ichkeul wetland include quarrying fishing, grazing of cattle, sheep and goats. Over-grazing is causing serious degradation and causing erosion, as well as affecting the water buffalo (Bousquet, 1988). Poaching, illegal hunting and overfishing are further activities in the Ichkeul wetland ecosystem. However, there is intensive agriculture, plowed land, orchards and pasture in both densely populated Ichkeul and Bizerte catchments, so the wadis have been dammed for freshwater (Koundouri et al., 2006).

The area around Bizerte lagoon is much more developed and densely populated. Economic sectors and activities include industry (petrochemical, metallurgical, textile, agro-alimentary, and cement), farming, animal rearing, aquaculture, fisheries, shipping and port, tourism.

These activities exert various direct, anthropogenic pressures on the lagoon and lake wetlands. Bizerte wetlands are affected by pressures from domestic sewage, industrial waste, atmospheric pollution, farmland runoff, effluents from fisheries and bivalve aquaculture (Béjaoui et al., 2010). The urban and industrial effluents are mainly discharged in the southeast, southwest and the north sectors of the lagoon wetlands. The southeastern sector is affected by the domestic and industrial effluent through the Guenniche River, the southwestern sector by the steel factory discharge, and the northern sector by urban wastes and sewage effluent. The mismanagement of the fisheries sector has resulted in an increase in the numbers of illegal fishing boats. The fishing pressure has decreased the stock to such a low level that the reproductive capacity is in peril (DGPA, 2012).

The main, direct, anthropogenic pressure on the Ichkeul wetland comes from the dams that have changed the hydrology and sediment supply to the lake. The dams have modified the connectivity and hydrology of both the Ichkeul and Bizerte wetlands. The changes in hydrology and freshwater supply in the lake and lagoon have altered the water equilibrium between the wetlands, rivers, lake, lagoon, and the sea (Smart, 2004; Saied and Elloumi, 2007). A lock on the Tinja channel was constructed in 1996 to control salinization and the decline of the high biodiversity (IUCN, 1994). Drainage canals have lowered water in the Ichkeul wetland, so livestock now graze formerly inaccessible reedbeds. Open cast quarrying threatens the wetland ecosystem and pollutes the lake water (Bousquet, 1988).

Direct, anthropogenic pressures affect the state of the environment and ecology of both wetlands. The dominant flora 
of Ichkeul wetlands was extensive meadows of Potamogeton pectinatus L., the major food source for wintering waterfowl (Bousquet, 1988), and Ruppia cirrhosa (Petagna Grande), (Hollis, 1986; Bureau Central d'Etudes pour les Equipements d'OutreMer [BCEOM], FresinusConsult, CESalzgitter, and STUDI, 1995; Tamisier et al., 2000) until the early 1990s. The area occupied by $P$. pectinatus varied both annually and seasonally, with a summer-autumn maximum and a late winter minimum (Hollis et al., 1977; Hollis, 1986). The annual yield of $P$. pectinatus was cropped largely by wintering birds. However, rising salinity now restricts the growth of this species (Zairi, 1997). The wetland marshes were famous for their variety of hydrophilic vegetation, especially Scirpus maritimus, important for geese (Anser anser), (Hollis et al., 1977; Hollis, 1986). Poaching, illegal hunting and overfishing have caused a decrease in biodiversity. The damming of the water supply to Ichkeul lake has led to evaporation of the Scirpus maritimus marshes, which have been replaced by invasive, annual weeds. Salt-loving plants have replaced freshwater species in the wetland marshes. Industrial development in the catchment has contributed to the contamination and pollution of Ichkeul lake by organo-metals and organic chemicals (Zairi, 1997).

The pressures have also affected the state of Bizerte lagoon. Run-off of fertilizers led to eutrophication and increases in water temperature have stimulated microbial activity, hypoxia and eutrophication of Bizerte lagoon (Essid et al., 2008; Ben Omrane et al., 2010; Fertouna-Bellakhal et al., 2014). The relatively high levels of organic matter recorded in the wetland sediment caused a decrease in dissolved oxygen causing repeated fish kills (Béjaoui et al., 2008). Industrial contamination is the source of metal ( $\mathrm{Pb}$ and $\mathrm{Zn}$ ) in the sediments of Bizerte (Zaaboub et al., 2014), and accumulation of $\mathrm{Zn}$ may contribute to sediment toxicity. Increase of marine navigation contaminates the lagoon and wetlands with Polycyclic Aromatic hydrocarbons and Polychlorinated biphenyls. There are occurrences of harmful algal blooms (HAB) of species belonging to the genus Alexandrium in Bizerte lagoon (Turki et al., 2007, 2014; Sahraoui et al., 2009), possibly related to the increase in internal marine navigation and introduction of non-indigenous dinoflagellates from ballast water.

The degradation of the state of the environment has led to a loss of ecosystem services. The provisioning services of fishing and aquaculture of Bizerte lagoon and wetland are threatened by changes in salinity, pollution, harmful algal blooms and overfishing. The Tunisian government created Ichkeul National Park in 1977 as an internationally important wintering ground for waterfowl (Scott, 1980; Hollis, 1986). The lake and wetlands of Ichkeul are the most important stopping-over point in the Western Mediterranean basin for migrating birds (150,000250,000), as recognized by the Ramsar Convention List, the MAB Biosphere Reserve, and the UNESCO World Heritage List (Hollis et al., 1977; Tamisier and Boudouresque, 1994; Casagranda et al., 2006). The deteriorating state of the environment and ecosystem has consequences on the supporting and regulating ecosystem services provided by the Ichkeul wetland, especially a decrease population of migratory birds such as ducks, geese, storks, and pink flamingoes. Important species are Anse ranser, Anas penelope, Aythya farina, and Fulica atra (Tamisier and
Boudouresque, 1994; Tamisier et al., 2000). The degradation meant that Ichkeul National Park was placed on the list of World Heritage in Danger in 1996, while in 1998 data from IUCN showed that the increase in salinity threatened the value of the World Heritage site.

There are also impacts on human welfare such as food safety, public health, decreased fisheries and aquaculture revenues. Mussel production in Bizerte lagoon has decreased in recent decades due to harmful microalgae and mortality (Sahraoui et al., 2009; Turki et al., 2014) with considerable economic losses (Sahraoui et al., 2009; Turki et al., 2014) and this is an obstacle to the development of shellfish aquaculture industry. This has also been associated with increased bacterial activity (Sakka Hlaili et al., 2006, 2007; Essid et al., 2008; Ben Omrane et al., 2010; Fertouna-Bellakhal et al., 2014). The decrease of fish stock and diversity has also caused a decline in jobs of fishers and aquaculture farmers. Ichkeul Park is a popular destination for eco-tourism and cultural heritage, thus contributing revenues to the local economy through cultural services, although eco-tourism has decreased. Numbers of visitors were 23,000 in 1987 and 2,500 in a 6-week period of 1988 (IUCN, 1994). However, visitor numbers decreased by 2016, partly because of security issues in the tourism sector.

Indirect pressures on both wetlands are expected to increase with climate change. In particular, the hydrological imbalance between Lake Ichkeul and Bizerte lagoon (Tamisier and Boudouresque, 1994; Tamisier et al., 2000), initiated by the reduction in freshwater supply to the lake, will be aggravated by sea-level rise in the lagoon, (Casagranda et al., 2006; Koundouri et al., 2006; Béjaoui et al., 2008; Béjaoui et al., 2010).

\section{Watamu, Mangrove Wetland of Mida Creek, Kenya}

Mida Creek covers an area of $31.6 \mathrm{~km}^{2}$ at Watamu, on the Indian Ocean coast of Kenya (Dahdouh-Guebas et al., 2000). The climate is tropical with temperatures of $26-32^{\circ} \mathrm{C}$. The monsoons bring two, distinct rainy seasons, in April/May and in October/November (Gang and Agatsiva, 1992). Mida Creek has habitats that include mangrove forest, rock outcrops, sandflats, seagrass beds, and coral reefs adjacent to deeper waters. The mangroves dominate the wetland occupying 1,746 ha, (DahdouhGuebas et al., 2000; Kairo et al., 2002). Seven of the nine mangrove species found in Kenya occur in Mida Creek with abundant Rhizophora mucronata, Avicennia marina, and Ceriops tagal and more sparsely distributed Sonneratia alba, Xylocarpus granatum, Bruguiera gymnorhiza, and Lumnitzera racemosa, (Kairo et al., 2002).

Mida Creek is part of the Watamu-Malindi marine protected area established in 1968 and was designated in 1979 as a Biosphere Reserve by UNESCO (Dahdouh-Guebas et al., 2000). Nevertheless, human activities continue in the national marine reserve, because traditional harvesting of resources, as well as research and tourism, are allowed. The traditional communities use the mangrove forest as a source of food (honey, crab, and fish), construction material, firewood, and medicinal purposes (Gang and Agatsiva, 1992; Dahdouh-Guebas et al., 2000). The population live in traditional villages around the administrative sub-locations Gede $(\sim 29,600$ people $)$ and 
Matsangoni ( $~ 16,000$ people) and tourist developments around Watamu of $\sim 26,000$ people (2009 census in KNBS, 2010). Associated activities include nature watching, recreational fishing and boating, scientific research and education (Frank et al., 2017; Owuor et al., 2017, 2019a). Farming activities include cultivation of coconuts, cashew nuts and mangoes. Artisanal fishing using traditional methods is also important activity (Gang and Agatsiva, 1992). Cultural shrines associated with the forest are important to the traditional communities in Mida Creek (McClanahanan et al., 2005).

The human activities exert direct pressures by the selective removal of specific species and the increasing encroachment of settlements, within the reserve. Other pressures are land derived pollutants from agricultural runoff, untreated sewage, litter and oil spills due the substantial increase in maritime activity (Lang'at and Kairo, 2008).

These pressures result in a degradation of state of the mangrove. This includes a decline in the mangrove cover and a change to the mangrove community structure (Owuor et al., 2017), contributing to the overall rate of decline in mangrove cover for Kenya of between $0.76 \%$ per year between 1985 and 2015 (Kirui et al., 2013). High sediment loads, due to poor agricultural practices in the hinterland, have been particularly destructive for mangroves, causing siltation of aerial roots during periods of flooding, such as during the El Nino years of 1997 and 1998 (Lang'at and Kairo, 2008). Oil spills have also contributed to damage of mangrove aerial roots.

Mida Creek provides important ecosystem services (ES) for provisioning timber and firewood, medicinal uses, and food products; whilst its cultural services are spiritual shrines, educational, recreational, and tourism (Owuor et al., 2017; Frank et al., 2017; Newton et al., 2018). The supporting and regulation services of the creeks are critical for providing shore protection, water filtration, pollution regulation, and habitat to many organisms (Frank et al., 2017; Owuor et al., 2017, 2019a,b). The mangroves provide an important habitat for fauna, including commercially important crabs and fish, as well as providing a breeding ground and nursery (Nagelkerken et al., 2000; Granek et al., 2009). Mangroves have a high capacity to sequester and store carbon (Alongi, 2014), which is an important ecosystem service contributing to mitigation measures such as Reduced Emissions from Deforestation and Degradation (REDD), (Webber et al., 2016).

Indirect pressures related to climate change and sea level rise (SLR) are not well studied for Africa (Ward et al., 2016). However, two studies in Kenya provide some idea what could happen to the mangroves of Mida Creek in the future, with Kebede et al. (2010) predicting an SLR of $1 \mathrm{~mm} \cdot \mathrm{y}^{-1}$, although Lang'at et al. (2014) observed an increase of $4.2 \mathrm{~mm}^{-1}$ in surface elevation in mangrove stands from Gazi Bay, approximately $150 \mathrm{~km}$ south of the Creek.

\section{Malanza Wetlands, São Tomé and Príncipe}

São Tomé is an equatorial island, west of Gabon with two main seasons, rainy September-May and dry June-September. The
Malanza mangrove is only $0.7 \mathrm{~km}^{2}$, however, it is the largest in São Tomé and located in Obô Natural Park (PNOST), created in 2006. The wetland is constituted by a complex network of shallow, narrow, channels flowing to a central basin that is connected to the Atlantic through a constricted opening. The fringing vegetation is dominated by the black mangrove Avicennia germinans and the red mangrove Rhizophora racemosa.

There are two village communities, Malanza and Porto Alegre. Each village has a population of approximately 500 inhabitants who rely on coastal fisheries and agricultural activities. Fisheries inside Malanza lagoon include a high percentage of juveniles (Félix et al., 2017). The communities of Malanza and Porto Alegre organize boat tours that complement the income of local families.

The human activities exert several anthropogenic pressures on the wetland. A challenging pressure is the introduction of nonindigenous species, such as the tilapia Oreochromis mossambicus, which tends to be an aggressive invader (Canonico et al., 2005) in the wetland. The construction of a road-bridge that crosses the lagoon to give access to the village of Porto Alegre, severely restricts the flow of water and sediments (Félix et al., 2017). Agricultural intensification and oil palm monoculture threaten the natural wetland habitats and biodiversity.

The current state of the environment includes water column stratification and hypoxia/anoxia at the bottom and wetland sediments. Oxygen depletion can reduce vegetation and biodiversity, as well as affect fish and shellfish stocks. Inputs of nutrients from fertilizer run-off may also promote future eutrophication.

The state changes affect the provision of wetland ecosystem services. The local population is poor and very dependent on the natural resources available in the wetland. Provision of food (e.g., fish and shellfish protein) is affected by the current oxygen depletion at the bottom, with reports of declining fish populations and impacts on human welfare. The wetland also provides an opportunistic feeding ground for marine species and a nursery for the juveniles (Félix et al., 2017). Moreover, palm tree plantations have also reduced the land area available for local agriculture. On the other hand, recreational and cultural activities related to tourism have been increasing, providing a valuable contribution to local subsistence.

Indirect pressures from climate change and sea level rise will affect the future of this mangrove, since the whole system is only just above present sea level. In recent years, the ocean has been claiming a sand bar to the west of the system, near Praia Jalé. If this sand bar disappears, it may affect the entire dynamic of the region, effectively turning the southern tip of the island of São Tomé into an islet, with consequences for the ecology of the mangroves.

\section{Coastal Wetlands in Asia Vembanad Wetlands, India}

Vembanad Lake is a RAMSAR site that spans three districts Alappuzha (Alleppey), Kottayam and Ernakulam, and comprises $4 \%$ of the state of Kerala, SW India. It is narrow $(0.8-6.9 \mathrm{~km})$, but the longest $(96 \mathrm{~km})$ and largest (area $1521.5 \mathrm{~km}^{2}$ ) wetland in India, running parallel to the coast and broadening in the 
south. Barrier spits separate the wetland from the Arabian Sea, to which it is connected by two tidal inlets, at Kochi $(400 \mathrm{~m})$ and further north at Azhikode $(250 \mathrm{~m})$. The wetland includes marshes, mangrove forests, a network of canals and backwaters, small islands and reclaimed land. The wetland has a freshwater southern zone and a saltwater northern zone. The total drainage area is $40 \%$ of the area of the State, and there are 10 main rivers draining into the wetland. The annual surface runoff is $2.19 \times 10^{10} \mathrm{~m}^{3}$, nearly $30 \%$ of the surface water resource of Kerala (Anon, 2016).

The Vembanad wetland supports a diverse flora and fauna, including small, isolated patches of mangrove (e.g., at Kumarakom, Vypeen, Kannamali, and Chettuva), (Anon, 2016). The Vembanad wetland and the Kumarakom Bird Sanctuary on the east coast support waterfowl migrating along the Central Asian Flyway and a large wintering population (Narayanan et al., 2011). Fauna also includes a large variety of reptiles and commercial fish (mainly oligohaline), valuable crustaceans, (e.g., prawns), and molluscs, (e.g., clams).

The population density $\left(1,103 \mathrm{~km}^{-2}\right)$ in the 2011 census was almost three times the mean for India, $\left(382 \mathrm{~km}^{-2}\right)$. There are many human activities in settlements along the wetland, including shipping, agriculture, fisheries, aquaculture, shell mining for lime and houseboat tourism on the famous backwaters. The town of Alappuzha is sandwiched between the wetland, the lagoon and the Arabian Sea and famed for its large network of canals that meander through the town. The major shipping port of Kochi (Cochin) is located at one of the inlets to the Arabian Sea and recently, the new container terminal at Vallarpadam has been added ${ }^{4}$. The 1,252 m long Thanneermukkom salt-water barrier, the largest mud-regulator in India, is located where the lagoon is narrowest and has changed the hydrology of the wetland. Thanneermukkom barrage was built in 1976 to prevent saline ingression during the dry season in the low lying Kuttanad region, known as the 'Rice bowl of Kerala.' Shallow parts have been bounded for punja cultivation, Padasekharam/low lying rice fields. Rice cultivation is the main crop, with extensive plantations of coconut, banana, tapioca, cereals such as millet, pigeon peas, peanut, and pawpaw grown as intercrops (Planning Commission Government of India, 2008). Constructed infrastructure includes roads across drainage canals, as well as a network of roads and bridges in the Kuttanad region, and commercial developments. Fermentation of coconut husk for coir manufacture is carried out extensively on the surface waters of the lagoon (Kumar, 2018). The black clam Villorita cyprinoides is harvested by hand picking or using a canoe for its shell rather than as shellfish (Laxmilatha and Appukuttan, 2002).

Changes in land-use from reclamation is a major and growing direct, anthropogenic pressure. There are extensive encroachments changing the land-use of the wetland for agriculture, especially rice cultivation (Planning Commission Government of India, 2008). Excess fertilizers and pesticides used in agriculture drain into the wetland system. Another major pressure results from changes in hydrology for irrigation and hydroelectric schemes affecting the connectivity of

${ }^{4}$ https://ernakulam.nic.in/vallarpadam-terminal/ wetlands and surface waters, tidal and inundation regimes, circulation and mixing patterns (Haldar et al., 2019). Untreated sewage is discharged directly into the lake from houses in the wetland, as well as from houseboats used by the tourism industry. Also, many rivers in the catchment area flow through industrial areas carrying polluted effluents to the wetland (Varkey et al., 2016). Indiscriminate exploitation of small-sized clams, closure of the Thaneermukkom Barrage, frequent dredging, pollution due to retting, effluents from shrimp processing plants/factories and extensive weed growth are major pressures on the wetland (Laxmilatha and Appukuttan, 2002).

The state of the environment and ecosystem of the wetland is affected by these pressures, especially south of the barrage at Thaneermukkom, which affects the distribution and ecology of the wetland. The area of Vembanad wetland has decreased by 465 ha from 2002 to 2014 (Varkey et al., 2016). Reduced connectivity and flushing has resulted in eutrophication (Varkey et al., 2016). It has also led to the proliferation of non-indigenous, invader species (Eichhornia crassipes and Salvinia molesta) from Latin America that are widely distributed and a threat to the wetland (Kumar and Rajan, 2012). The 2008-2011 fish count by the Ashoka Trust for Research in Ecology and the Environment (ATREE), recorded 67 species of fin fishes and 14 species of shellfish. Earlier studies indicated that the fish fauna of Vembanad was dominated by marine migratory species (56\%), but the 2011 fish-count indicated that salinity-tolerant, freshwater species dominated (69\%) and the marine migrants were reduced to $31 \%$ (Kumar and Rajan, 2012). Plastic bags, bottles and other wastes dumped in the wetland and lake settle to the bottom and adversely affect bottom feeders, e.g., gobids, and the fishes that attach their eggs to the benthic substratum, (Kumar and Rajan, 2012). A decline in carnivores and a dominance of omnivores (58\%) followed by $6 \%$ herbivores, $6 \%$ larvivores, and $2 \%$ detritivores also indicates organic pollution (Kumar and Rajan, 2012). The discharges of industrial effluents contaminate and pollute the wetland. The pollution load index indicates that the sediment is heavily polluted in the north and moderately polluted in the extreme south port region (Selvam et al., 2012). For example, there is severe and moderately severe enrichment of $\mathrm{Cd}$ and $\mathrm{Zn}$ with minor enrichment of $\mathrm{Pb}$ and $\mathrm{Cr}$ in the north. Mercury contamination is also higher in the north (Mohan et al., 2014). The presence of high mercury concentration in the subsurface sediment indicates historic, industrial mercury deposition.

The degradation results in the loss of ecosystem services in the wetland. The Thaneermukkom barrage has affected the production of fish and shrimp from the lagoon but has been successful in keeping the Kuttanad water fresh for agriculture (Varkey et al., 2016). The estimated annual mean fishery catch (provisioning ecosystem service) is $4774.46 \mathrm{t}$, only $10.1 \%$ in the south and $89.9 \%$ in the north (Asha et al., 2015). The main commercial species are marine penaeid prawns, clams such as Villorita cyprinoides that represents $70 \%$ of the production, cyprinoid fish and Meretrix meretrix (Kumar and Rajan, 2012). 
Furthermore, indirect pressures from climate change and rising sea levels are of concern as the entire wetland is low lying. Estimates indicate that a $1 \mathrm{~m}$ rise in sea level will inundate about $169 \mathrm{~km}^{2}$ of the coastal region around Kochi, especially areas adjacent to the tidal creeks, backwaters and lakes reaching inland areas far from the coast (INCCA, 2010).

\section{Sundarbans Wetlands, Bangladesh and India}

The Sundarbans coastal wetland on the south coast of Bangladesh and northeastern India is fed by the river Ganges and hundreds of tributaries. It includes the largest, single tract, mangrove forest in the world with a total area of $10,000 \mathrm{~km}^{2}, 62 \%$ in Bangladesh and $38 \%$ in India (Islam and Gnauck, 2009). This mangrove forest constitutes about $51 \%$ of the forest area of Bangladesh and about $50 \%$ of the revenue for the forestry sector (Islam and Gnauck, 2009). The Sundarbans wetland is famous for its diverse biodiversity, which includes about 334 species of plants, 282 bird species, 49 mammal species, 210 fish species, 63 reptile species, and 10 each of amphibians and molluscs (Rashid et al., 1994; Biswas et al., 2007). Several rare species such as the tiger (Panthera tigris), the dolphins (Platanista gangetica), and the crocodile (Gavialis gangeticus) are found in Sundarbans wetland (Gopal and Chauhan, 2006). Endangered species such as the tiger and dolphin epitomize the conflict between the loss of habitat (quantity and quality) and human activities in the Sundarbans wetland. In 1992, about 601,700 ha of forest reserve of the Sundarbans in Bangladesh, and in 2019, 423,000 hectares of the Indian Sundarbans were declared Ramsar sites ${ }^{5}$. In 1999, 32,400 hectares of the Sundarbans in Bangladesh part were declared a UNESCO World Heritage Site (Islam and Gnauck, 2009).

Human activities in the Sundarbans mangrove forest ecosystem exert multiple pressures on this coastal wetland and the over-exploitation of natural resources. Sundarbans has a population of over 3.5 million inhabitants, mostly living below the poverty level and heavily dependent on forest natural resources (e.g., fire wood, livestock fodder, timber, honey, and fishes) for their food and livelihood (Hoq, 2007; Ahmad et al., 2009). Households that are dependent on Sundarbans obtain important monetary benefits annually from capture fishery (U\$ $976 \mathrm{ha}^{-1}$ ), fuel energy (U\$ $80 \mathrm{ha}^{-1}$ ), honey (U\$ $53 \mathrm{ha}^{-1}$ ), and fodder (U\$ $26 \mathrm{ha}^{-1}$ ), (Rahman et al., 2018). Unplanned developments threaten this World Natural Heritage (Islam et al., 2018). Land-reclamation and polders in the 1960's increased agricultural land. Aquaculture farms cleared large areas of mangrove for shrimp ponds, without considering the externalities such as the chemicals from the effluents. Poor people, especially women and children, use illegal, fine-meshed push nets to catch of wild post larvae (PL) of Penaeus monodon shrimp. Barrages in the catchment (e.g., the Farakka barrage in the river Ganges) have decreased the freshwater flux to the wetland, especially in dry season February-June (Hoque and Alam, 1995; Wahid et al., 2007; Islam and Gnauck, 2009; Bahar and Reza, 2010). Dykes to protect from coastal flooding have also been constructed in the SW of Bangladesh, further disrupting the natural hydrology. The construction of the Rampal power

${ }^{5}$ https://rsis.ramsar.org/ris/2370 station (Bangladesh), a 1,300 MW, coal-fired power plant close to Sundarbans territory (Tamim et al., 2013; Islam and Al-Amin, 2019), has resulted in protest from environmentalist groups anxious about pollution of the Sundarbans wetlands. Consequences include atmospheric emissions and land storage of fly ash from the power plant (Tamim et al., 2013).

Human activities in the Sundarbans exert multiple pressures on this coastal wetland and the over-exploitation of natural resources. Pressures include modifications of hydrology, changes in land-use and encroachment into the forest, for example to construct aquaculture ponds, unsustainable harvesting of shrimp post-larvae, over-fishing and illegal logging. The balance of freshwater and seawater, to the mangrove wetlands (Islam, 2006) has been modified.

These pressures have affected the state of the environment and ecology of the Sundarbans wetlands (Islam and Gnauck, 2009; Rahman et al., 2010). Pressures such as oil pollution, metals and industrial waste, untreated sewage effluents degrade the environmental state (Iftekhar, 2004; Rahman et al., 2009; Islam et al., 2017; Ranjan et al., 2018). The water and soil salinity in Sundarbans area has increased due to low freshwater influx from upstream, which is the main cause of top-dying and dieback diseases of trees, especially the Sundari (Heritiera fomes) and Goran (Ceriops decandra), (Khan et al., 1994; Islam and Gnauck, 2009). The destruction of 9,500 ha of mangrove forest for shrimp cultivation has caused a dramatic decline in dominant mangrove species such as Excoecaria agallocha and Xylocarpus mekongensis (Iftekhar and Saenger, 2007) and widespread loss of biodiversity.

There is a loss of ecosystem services because of the degradation of the state of the wetland. The provisioning services that supply natural resources (mainly forest products) from the Sundarbans have declined since 1996 (Hossain et al., 2016). The reduction of fresh water flow from the river Ganges, the over-capture of wild shrimp post-larvae, the simultaneous bycatch of juvenile fish and crustaceans, salinity intrusion, uncontrolled tourism, inadequate planning and lack of ecosystem based management are effecting the biodiversity of Sundarbans ecosystems, hence affecting livelihood and food security of coastal community of Sundarbans region (Ahmed and Troell, 2010; Islam and Bhuiyan, 2018; Rahman et al., 2018; Islam, 2019). The collection of Penaeus monodon post-larvae destroys the larvae and juveniles of other shrimps, finfish, and other macro- zooplankton (Hoq et al., 2001). Therefore, the collection of shrimp PL from natural sources for aquaculture operations is directly influencing in reduction of wild fisheries (Primavera, 2006). The wild aquatic biodiversity (specially the benthic community) might be also in risk due to the toxicological effect of various chemicals used in shrimp ponds (Flaherty et al., 2000). The Sundarbans provide a regulating ecosystem service as a protective, natural boundary during cyclones, and in the last couple of decades it has protected over 10 million human lives from cyclonic storms (CEGIS, 2007). Clearing the mangrove for agriculture or aquaculture has a deleterious effect on this regulating ecosystem service.

With respect to indirect pressures, the population density and the susbsidence low-lying lands of the Sundarbans make them especially vulnerable to flood risk, whether from sea-level rise or cyclone storm surges (Brown et al., 2018). Like all coastal 
wetlands, the Sundarbans regions is at greatest risk due to global climate change, which will influence the distribution and productivity of Sundarbans resources and aquatic biodiversity (Loucks et al., 2010). An additional problem is the increased salinity of the wetlands that affects the distribution and survival of the mangroves (Dasgupta et al., 2017). The loss of the coastal protection ecosystem service of mangroves would only increase the vulnerability of the whole system (Barbier, 2016).

\section{Huang He (Yellow River) Delta Wetland, People's Republic of China}

The coastal wetland of the delta of the Huang He (Yellow River) is near the city of Dongying, in the Shandong Province, China. The area of the wetland is $18,000 \mathrm{~km}^{2}$ with a population of 5.2 million. The continental monsoon climate is warm and temperate ( $\mathrm{Li}$ et al., 2014) with a mean annual temperature range from 11.7 to $12.6^{\circ} \mathrm{C}$ and $\sim 200$ frost-free days. The mean annual precipitation is $530-630 \mathrm{~mm}$, with $70 \%$ of the rainfall during the wet, early summer from May to July (Li et al., 2014). The wetlands include various aquatic habitats such as rivers and channels, estuarine waters, coastal and salt lakes, ponds and reservoirs, shrimp and crab cultivation ponds (Cui et al., 2009). Migrating birds from northeast Asia and from the western Pacific rim use the wetland as an overwintering and breeding site.

The delta wetland is affected by huge pressures from several human activities especially agriculture, aquaculture of fish and petro-chemical industries (Li et al., 2014). Land-use changes have converted grassland and wilderness to cultivate salt-tolerant crops and grasses, clover, maize, cotton, and Chinese date. Shrimp ponds and saltpans have been constructed in large areas of the wetland (Zhang et al., 2011). There are also thousands of oil wells of the Shengli oilfield in the wetland.

These human activities exert direct pressures on the wetland. Intensive agriculture and the growth of urban areas have almost halved the area of natural wetlands from 1976 to 2008 (Chen et al., 2011). The construction of roads between the river and wetland has decreased the water supply to the wetland. The implementation of flow-sediment regulation has reduced connectivity and modified the hydrological conditions, hence the wetland landscape (Bai et al., 2012). River diversions for irrigation have altered the hydrology and decreased the river fluxes to the wetland (Ottinger et al., 2013). Over-extraction of deep groundwater causes land subsidence, which could accelerate local relative sea level rise, increasing the vulnerability to storm surge, flooding, saltwater intrusion and coastline erosion (Liu and Huang, 2013). Saline aquaculture may cause secondary salinization in the future. The oil exploration and flowsediment regulation could cause contamination by petroleum hydrocarbon, polycyclic aromatic hydrocarbons, arsenic, and cadmium (Wang et al., 2009; Bai et al., 2012).

The state of the ecosystems in the wetland was seriously affected by the depleting water resources, degradation of soil quality, pollution, agricultural, and industrial activities (Zhang et al., 2016). Economic development has resulted in a decrease of the habitat for the red-crowned crane habitat by 5,935 ha from 1992 to 2008 (Wang et al., 2017). The coastal blue carbon storage in the delta has decreased by $10.2 \%$ during $1970-2010$ due to land use change (Ma et al., 2019). Since 2000s, the implementation of a wetland restoration project and a water regulation scheme (WSRS) has significantly improved the structure and functions of the wetland ecosystem. However, the altered flux and grainsize composition of sediments due to the implementation of the WSRS may in turn aggravate elemental imbalance, impacting estuarine and coastal geochemical processes and the wider ecosystem (Li et al., 2019).

There are impacts on human welfare from the loss of wetland ecosystem services. The lost wetland area and the decreased water supply has degraded bird habitats. Construction of dams in the catchment perturbs sediment supply, making the wetland vulnerable to erosion. Houses and oil fields on the coast have been partly destroyed by storm surges and coastal erosion (Liu and Huang, 2013). The increased salinity level in groundwater and soils caused by seawater intrusion has decreased agricultural production. Potential heavy metals and oil contamination from agro-activities and oil exploration taint seafood and are public health issues.

Indirect pressures from sea-level rise also affect the Yellow River Delta wetlands. The topography is such that the river delta has changed position many times in the past but it is now constrained by engineering projects. The combined effects of these changes, subsidence and sea-level rise threaten the wetland habitat, highlighting the need for a social-ecological adaptive management plan (Zhang et al., 2016). Nevertheless, the Yellow River Delta is one of the few large deltas in the world that can offset Sea Level Rise by 2100 due to the huge sediment input from the Yellow River (Giosan et al., 2014).

\section{Changjiang (Yangtze) Coastal Wetlands, People's Republic of China}

The Changjiang (Yangtze) River, the longest river in China, discharges into the East China Sea in a temperate climate zone near Shanghai. The Changjiang coastal wetlands are estuarine and meso-tidal. The wetland, including the intertidal land and the areas shallower than $6 \mathrm{~m}$ water depth, occupies an area of some $3,050 \mathrm{~km}^{2}$ at the beginning of the 21 st century. There are saltmarshes, mudflats, and estuarine shoals (Li et al., 2009). The deltaic areas are extensive, with a total area of around $25,000 \mathrm{~km}^{2}$, and they are densely populated, with more than 1,000 million inhabitants. Shanghai had a population of 22.3 million (Statutory City $=\mathrm{SC}$ ) to 34 million (Functional Urban Area $=\mathrm{FUA})$ in $2010(\mathrm{OECD}, 2015)$. In addition, there are other large cities in the Changjiang River delta, such as Nanjing (7.2 million SC to 11.7 million FUA) as well as Suzhou, Wuxi, Nantong, Changzhou, Yangzhou, Taizhou, Jiaxing, and Huzhou. The area is experiencing rapid changes in response to both natural processes (e.g., shoreline hydrodynamics and sediment dynamics) and human activities (e.g., land reclamation). The shoreline is often hit by typhoon induced storm surges, which has a trend of enhancing intensity in response to sea level rise and the warming climate (Gao et al., 2019).

Intensive human activities exert direct pressures on the Changjiang coastal wetlands. The most important ones include: dam construction that causes modifications to hydrology and sediment dynamics; rapid urbanization in the catchment 
and increased pollutant discharges; land reclamation along the estuarine shoreline; artificial introduction of the Spartina alterniflora species into the region; and projects for water resource utilization. More than 50,000 dams have been built in the Changjiang catchment, of which the Three Gorges Dam is the largest. As a result, the sediment discharge has been reduced by up to $70 \%$ since the 1980 s (Yang et al., 2005) and the suspended sediment concentration of the river water in the downstream section is significantly reduced (Yang et al., 2018). Land-reclamation for the urban development of Shanghai and Pudong has been an important activity up to the 1990s.

These activities have resulted in pressures on the wetland. Foremost are pressures on the hydrological system and delivery of sediments. Although the total water discharge remains almost the same, the timing of the delivery has changed with an increase in the dry seasons but a decrease in flood seasons. The Changjiang River delta reached the limits to its expansion after the construction of the Three Gorges Dam (Gao, 2007), and shoreline recession is now occurring in some places. Water supply to Shanghai is a critical issue. The treatment of the water from local small rivers is costly, and the main body of the estuary is affected by saline water intrusion. To solve this problem, reservoirs to store Changjiang freshwater have been built on deltaic islands such as Chongming (the largest) and Jiuduansha (newly formed). The largest reservoir, Qingcaosha, is on Changxing Island. It was completed in 2010 and provides some 7.2 million $\mathrm{m}^{3}$ of water per day, which is sufficient for 11 million people. Land reclamation has declined because the shoreline progradation has slowed down in response to the reduction of river sediment input. The rapid industrial, agricultural, and urban development has also resulted in increased pollutant discharges, including nutrients, heavy metals, pesticides and micro- plastic particles (Zhao et al., 2014). A non-indigenous species from North America, Spartina alterniflora, was artificially introduced into the wetland in the 1980s. It has expanded rapidly (Gao et al., 2014) since the 1990s and is now a dominant species in the Changjiang wetland (Li et al., 2009). The local nematodes and macrobenthic invertebrates have adapted to the S. alterniflora marsh, but the native marsh plants such Scirpus mariqueter and P. australis are affected (Chen et al., 2004, 2007; Zhao et al., 2009). S. alterniflora occupies a lower position in the tidal flat compared with the native species, so land reclamation is primarily of Scirpus mariqueter and P. australis marshes and these species have very limited space to expand outside the sea dykes. Ecological restoration has become a recent focus for regional development. Five Nature Reserves were established by the State Council in 2005 to protect the coastal wetlands, including the Chongming Dongtan National Nature Reserve. The Ramsar Convention listed it as a 'wetland of international importance' in 2002. New techniques and measures have been adopted to create wetland along the shorelines that are artificially modified. For example, underwater dykes are built parallel with the sea dykes to enhance the accretion rate and the area of intertidal zone, so that new marshes can be formed in front of the sea dykes.
The anthropogenic pressures from human activities have changed the state of the environment and ecosystem. Land reclamation, the reduction of riverine sediment input and decreasing deltaic shoreline growth have led to a large-scale decrease of coastal wetland area and loss of biodiversity. The wetland area in 2016 was less than half that of 15-20 years prior. The native saltmarshes are disappearing because of lack of space for expansion. Although some are conserved in the nature reserves, future morphological changes due to sediment accretion may eventually destroy these last refuges. The S. alterniflora marsh initially expanded, but now its area is also decreasing because of reclamation. If the wetland loss from reclamation is not compensated by the various ecological restoration schemes, future land use requirements for urban development will further reduce the area. Contamination and pollution of the estuary affect the ecosystem health. Water quality becomes a critical problem due to the enhanced input of heavy metals and organic chemicals (Cao et al., 2012). The contaminant concentrations are high in the wetland sediment of the estuary. The pressure from excessive loading of nitrogen from fertilizer, manure, sewage and aquaculture stimulate eutrophication, hence Harmful Algal Blooms and hypoxia events occur with an increased frequency of occurrence and spatial extent (Bianchi and Allison, 2009).

The present changes taking place in the wetlands have consequences on the ecosystem services. The loss of area decreases all the ecosystem services of the wetland such as coastal protection, denitrification and carbon sequestration. The wetland provided fish spawning grounds and a nursery feeding place for young fish. Thus, the life cycle of fish species in the 3 traditional fishing grounds near the Changjiang River mouth is affected. The loss of $71 \%$ loss of wetlands from 1990 to 2000 has caused an estimated loss of $62 \%$ of the total value of ecosystem services in the Chongming Dongtan Nature Reserve (Zhao et al., 2004). Although S. alterniflora marshes increased the primary productivity, some sea birds (e.g., Charadriidae and Scolopacidae) that need mudflats are affected, and the natives have insufficient space to grow (Ma et al., 2007, 2009; Li et al., 2009). How the ecosystem functioning is influenced by $S$. alterniflora needs further investigation.

Efforts have been made by the Shanghai government to reduce the negative effects of wetland changes on human welfare. One of the responses has been the establishment of nature reserves and areas for ecological restoration. The fishery catch is decreasing, partly because of the insufficient wetland space (Jin et al., 2007). The management response would be to maintain the stability of the native saltmarshes and simultaneously to use the S. alterniflora marsh as an ecological restoration tool. Soft engineering could be adopted to increase the space for wetland development, and pollutant input should be controlled to improve the water quality of the estuary. For these purposes, efficient management is required, in the context of the long-term climate and sea level factors and the short- term anthropogenic influences (Cheng and Chen, 2016; Ding, 2016).

Indirect pressures also affect the Changjiang (Yangtze), where a megacity is built on a low-lying, sinking deltaic wetland, in 
a zone prone to supertyphoons that is also very vulnerable to flooding and storm surges (Cui et al., 2015).

\section{Mekong Delta Wetlands, Vietnam}

The Mekong delta in the south of Vietnam includes 13 provinces occupying $40,600 \mathrm{~km}^{2}$ and is home to about 18 million inhabitants. Here, the Mekong drains via nine branches into the South China Sea. The subtropical delta undergoes distinct dry and rainy seasons. The delta includes temporarily inundated sandbars and mudflats, as well as several types of wetlands. These are: salt marshes; coastal mangrove ecosystems, such as Ca Mau National Park, Soc Trang, and Bac Lieu; reed wetlands, such as Ha Thien Plain and Tram Chim National Park (Plain of Reeds); and peat swamp wetlands, such as U Minh Thuong National Park. Several National Parks and nature reserves have been established in the Mekong Delta wetland. The area of mangrove in Mekong delta coast is 100,000 Ha. These mangrove forests are especially biodiverse with 98 species of trees, 36 species of mammal, 182 species of birds, 34 species of reptile, 6 species of amphibians, and 260 species of fishes. The main cities in the delta are Can Tho, Ho Chi Minh, Ca Mau, Bac Lieu, My Tho, Tra Vinh, Soc Trang cities and these are growing rapidly in population and area.

The main human activity is rice crop cultivation in rice paddy fields that are human controlled wetlands. Some are protected by complex diking systems and are intensively farmed, yielding 2, 3, and recently up to 4 harvests per year. Some paddies are under less intensive use and used as fishing grounds during the flooding season (Duy et al., 2015). Illegal clear cutting of mangroves continues in strictly managed and protected regions, such as the famous Can Gio Mangrove Biosphere reserve (Kuenzer and Vo, 2013). These illegal activities are hard to monitor and law enforcement is still weak. The overall socio-economic transformation, urbanization (e.g., the Delta Cities of Ca Mau, Soc Trang, Ben Tre, and especially Can Tho, just to name a few), and industrial expansion (petrochemical and coal/fuel) ongoing in the delta (e.g., sea-food processing and agro-industry especially around Can Tho and Long Anh) lead to a general overexploitation of resources, including overfishing (Pangasius, sting ray, catfish, and elephant fish to name only a few), unsustainable sand dredging, and the sale of topsoil. Economic activities are rice cultivation, animal husbandry (chicken, ducks, pigs, and cows) and aquaculture (especially shrimp and Pangasius). Extensive mangrove areas have been destroyed by the rapid expansion of coastal aquaculture (Kuenzer and Vo, 2013; Vo et al., 2015).

Many human activities exert direct pressures on these fragile wetlands. The construction of dykes, dams, urban, and industrial areas affect the hydrology and connectivity of the wetland. Coastal engineering activities are often driven by the hope for economic benefits and are executed for ministerial line agencies and related companies. These result in the ongoing closure of Mekong River main stem and tributary channels, decreasing connectivity. Wetland connectivity is decreased as the network of river branches and canals in the delta are increasingly obstructed by dykes, levees and sluice gates. The same applies to terrestrial ecosystem connectivity, which is decreasing due to fractionation by highways and roads. These are aggravated by the decrease in sediment loads from the upstream areas (Kuenzer et al., 2013).

These pressures affect the state of the wetlands, so that flora and fauna biodiversity is declining. The state of the water quality affected by fertilizer, pesticides and endocrine disruptors from rice farming, vegetable cultivation and animal husbandry. Furthermore, chemicals and antibiotics used in aquaculture ponds contaminate groundwater, soils, and the food chain (Ottinger et al., 2016). Elevated levels of pesticide have resulted in water pollution with traces detectable in ground, surface and even locally filled bottled drinking water (Toan et al., 2013). The area of area of mangrove in Mekong delta coast is decreasing with rate of $5 \%$ per year induced by human activities.

The deteriorating state of the wetland affects the delivery of ecosystem services. Healthy mangroves provide: provisioning services, e.g., fire wood, construction wood, medicinal products, honey, and fish; supporting, e.g., breeding grounds; protecting services, e.g., erosion and storm control; regulating services, e.g., water filtration and buffering capacities; cultural and recreational services, e.g., resting, eco-tourism, and spiritual activities (Vo et al., 2012, 2015; Kuenzer et al., 2013). The conversion of natural reed wetlands decreases their delivery of ecosystem services. These include a loss of provisioning ecosystem services, e.g., roofing and weaving material, fish supply; ecosystem services, e.g., water filtration and cleansing; and cultural- recreational ecosystem services (Vo et al., 2012, 2015; Kuenzer et al., 2013). Natural mangrove belts acted as barriers against high tides, storm surges and general sea level rise. The loss of these mangroves results in increased salt-water intrusion into the aquifers and soils of the delta.

The activities and related pressures exerted on the Mekong wetland have led to partially irreversible impacts on human welfare, especially affecting the rural poor who depend on natural resources for their livelihood. Artisanal fishers report a loss of fish species and decreased catch landings. Salt-water intrusion affects small-scale rice farmers. The rural population often drink untreated ground and surface water and suffer from intestinal problems and other health issues. Boat-dependent mobility is impaired by an increased regulation of water ways. Many typical, traditional lifestyles are likely to disappear in the next years, including floating markets, artisanal clam collection and fisheries, small-scale water transportation and complex, sustainable farming approaches, such as the multispecies duckrice-vegetable agriculture. This will entail a loss of cultural values and an overall decrease of the unique character of the Mekong delta wetland.

Climate change and related sea level rise are the main causes of indirect pressures in the wetland, including coastal erosion and salt-water intrusion. Managing flood risks in the Mekong Delta is a serious challenge in the context of climate change and socioeconomic developments (Hoang et al., 2018). 


\section{Coastal Wetlands of Oceania}

\section{Mangrove Forests of the Gulf of Papua,}

\section{Papua New Guinea}

The Central Highlands of Papua New Guinea are drained by the rivers Purari, Kikori, and Fly that pass through regions of extremely high rainfall and into a complex of tide- and riverdominated estuaries, delivering (384 Mt $\mathrm{a}^{-1}$ of sediment and $470-690 \mathrm{~km}^{3}$ water into the Gulf of Papua) (Aller et al., 2008). The wetlands are dynamic, with accretion and erosion occurring simultaneously indifferent parts of the deltas, with delta-front erosion of up to $43 \mathrm{~m}$ per year over the period 1973-2002 (Shearman, 2010). There are $3,780 \mathrm{~km}^{2}$ of wetland mangrove on the Gulf of Papua (Bryan et al., 2015), the largest, virtually pristine mangrove forests in the Asia-Pacific Region (Cragg, 1983), and particularly diverse (Duke et al., 1998). Pioneering species, e.g., Sonneratia lanceolata dominate accreting shorelines. Mature forests with canopies of up to $30 \mathrm{~m}$ are dominated by Rhizophora and Bruguiera. Transitional forests occur at the boundary with freshwater habitats (Cragg, 1983). There are large areas of pure Nypa palm stands in low salinity parts of the deltas. The mangrove wetlands are nursery grounds for fish, crabs, and prawns, (Frusher, 1983). Offshore of the mangroves, there are feeding and breeding grounds for commercially harvested prawns (Gwyther, 1983), and rock lobster (Dennis et al., 2001).

Human activities in the immediate vicinity of this huge mangrove are remarkably small. Four to five hundred years ago, traditional trading Hiri voyages traversed the Gulf (Barker et al., 2015; David et al., 2015). There are no urban areas but some villages on sand bars at the seaward edge or just inland of the mangrove rather than within the mangrove (Cragg, 1983). The population is low, approximately 107,000 , and relies on subsistence utilization of a range of mangrove resources: mangrove wood for poles for house construction, fuel and tools; edible mangrove fruits and palm hearts; medicinal uses and dyes (Liebezeit and Rau, 2006); thatching and basket weaving using Nypa fruticans fronds. Offshore there is one of the most commercially important fisheries in Papua New Guinea - the demersal prawn trawl fishery that gains an income of (US $\$ 3 \mathrm{M}$ per year through a local fishing fleet) (Kompas and Kuk, 2008; White et al., 2019).

The low population and subsistence utilization of mangrove resources represent only a low, local direct pressure at present. The estimated use of fuel wood is only $6.4 \mathrm{~kg}$ person ${ }^{-1} \mathrm{~d}^{-1}$ and construction wood at $0.6 \mathrm{~m}^{-3}$ household ${ }^{-1} \mathrm{a}^{-1}$ (Page et al., 2016). The main pressures are from human activities elsewhere: the large, commercial logging concessions inland of the wetland (Bryan et al., 2015); the oil pipelines from the highlands at Kutubu through the mangrove forests to the Kumul Marine Terminal offshore; and the huge Ok Tedi open-pit gold and copper mine is in the watershed of the river Fly. Mine tailings have increased the sediment load at peak rainfall (Shearman et al., 2013), transporting copper in dissolved and particulate form (Bolton, 2009).

Direct pressures may increase as the area is further developed in the future. Logging inland of the mangroves is likely to increase sediment input to the wetland and may require construction of coastal log-loading facilities. The potential commercial exploitation of ethanol production from tapping Nypa syrup has been explored but not exploited. There have been evaluations of potential for pulp wood and wood chips, but the soft sediments make harvesting problematic. Bark from Rhizophora trees was used to produce tannin extract (cutch) in a factory that operated between 1954 and 1957, but this activity ceased due to competition from alternatives to cutch (Percival and Womersley, 1975). The construction of a hydroelectric dam on the Purari River (Wabo) has not yet taken place. A multidisciplinary environmental impact study of plans predicted a reduction in sediment load and increased predation on prawn larvae, but no significant effects on delta fertility (Cragg, 1983). A project to exploit natural gas envisages an additional pipeline from the highlands into the Gulf.

The effect of these pressures may affect the state of the wetland and will entail a loss of ecosystem services such as supporting services, e.g., the high primary production and the nursery function for fish and crustaceans. Unusually high bacterial decomposition rates of sediment organic carbon leads to close benthic-pelagic coupling supporting the Gulf of Papua prawn fishery (Alongi, 1995). The regulating services of the mangrove forests help to stabilize the sedimentation and erosion of the delta. Furthermore, the sequestration of carbon by the Papua New Guinea mangroves is a globally significant ecosystem service: $2.9 \%$ of global carbon stocks in mangroves is estimated to be in Papua New Guinea mangrove forests (Hamilton and Friess, 2018). This is the 5th most important mangrove ecosystem in the world, in terms of carbon stocks once the additional offshore sequestration is combined. Dead plant matter is rich in the lignocellulose complex, which is more resistant to break down than marine-generated particulate organic matter, particularly under anoxic conditions in sediments (Cragg et al., 2020). Part of the forest detritus and almost all subterranean roots are retained, accounting for the exceptionally high carbon sequestration capacity of mangrove wetlands, particularly in New Guinea (Sasmito et al., 2020). An estimated $1.7 \times 109 \mathrm{~kg} \mathrm{a}^{-1}$ of the organic carbon, derived from the vascular plants and plankton of the mangroves, is exported through the Fly delta to the Gulf of Papua and the Coral Sea Robertson and (Alongi, 1995). The residence-time of soil organic matter is longer in marine sediments (Goni et al., 2006), so $13-27 \%$ of the organic matter accumulates long-term offshore (Aller et al., 2008).

Indirect pressures from climate change may alter rainfall patterns, hydrology, intensity and frequency of storms affecting the delta region. Sea level rise is interacting with subsidence of the delta sediments in affecting mangrove distribution (Shearman, 2010).

\section{SUMMARY OF THE MAIN DIRECT PRESSURES ON COASTAL WETLANDS AND CONSEQUENCES}

The Millennium Ecosystem Assessment [MEA] (2005) identified that human population growth and economic development lead to the degradation and loss of coastal wetlands. Anthropogenic 
degradation and loss of wetland was mainly due to landuse changes, construction of infrastructure, water extraction, eutrophication and pollution, overharvesting of commercial species and overexploitation of natural resources, as well as the introduction of non-indigenous species (Millennium Ecosystem Assessment [MEA], 2005).

We identified that the most important human activities exerting anthropogenic pressures on coastal wetlands can be placed in 2 groups: (i) land reclamation and conversion to agriculture, aquaculture, ports, and urban areas; and, (ii) construction of dams, dykes, polders, drainage channels, dredging that modify the natural hydrology, connectivity, and sedimentology. Thus, the main anthropogenic pressures are landuse change and changes in hydrology, as well as connectivity. The main anthropogenic pressures on the coastal wetlands included in this overview are summarized in Supplementary Table S1. The relationship between these human activities in or around coastal wetlands and resulting anthropogenic pressures on the environment and ecosystem are summarized in Supplementary Table S2.

The anthropogenic pressures (direct and indirect) alter the dynamics of ecosystem function of the coastal wetlands. This affects the natural resilience of the systems and increases their vulnerability. This overview is summarized in Figure 2. Damming in the catchment disrupts the sediment fluxes to coastal wetlands. This leads to erosion and subsidence, (Syvitski and Saito, 2007; Syvitski et al., 2009). Wetlands are dynamic systems, illustrated by the 'wandering mouths', of deltas, such as the Huang He (Yellow River) and Mississippi. In the case of dynamic, coastal lagoons such as the Ria Formosa, inlets open and close. Humans try to stabilize the position of river mouths and inlets for shipping, and channels are dredged to accommodate ships of increasing size. These modifications in the catchment and at the mouth cause changes to the sedimentology and hydrology. Over-extraction of water for agriculture is another common feature that changes the freshwater-saline water balance, so that wetlands that naturally vary from freshwater to saline become increasingly saline. The linked coastal wetlands of Bizerte lagoon and Ichkeul lake illustrate the dramatic effects of loss in connectivity. Changes in hydrology, flow rates and timing of freshwater inputs to estuarine wetlands affects the flora of the wetlands, whether it is seagrass, saltmarsh or mangrove. The vegetation is fundamental to the ecosystem services of the coastal wetlands and have dramatic impacts on human welfare, for example, provisioning services such as fish catch (Kennedy and Barbier, 2016). A holistic understanding of the interlinked hydrology, sedimentology and biology is fundamental for the management of estuarine systems such as coastal wetlands (Alber, 2002). This is particularly important for the assessment of diffuse sources, for example nutrient pressures from farming activities such as fertilizer application.

Another important and widespread anthropogenic pressure is the point source discharge of effluents by industry, farms and domestic sewage shown in Supplementary Table S3. Effluents, especially from industries, can contaminate and pollute wetlands, while eutrophication may result from the discharge of effluents that are rich in organic matter and nutrients shown in Supplementary Table S4.

Most of the anthropogenic pressures identified in this overview correspond to the types I to $\mathrm{N}$ of "anthropogenic hazards" from the typology of Elliott et al. (2014) and are summarized in Supplementary Table S5. The value of ecosystem services of a wetland, e.g., the mangroves of Papua Guinea can be globally significant, but the lack of understanding about the value of coastal wetland ecosystem services (Newton et al., 2018) continues to contribute to their degradation. Externalities and the long-term value of ecosystem services are often ignored, for short term, economic gain and/or development. Even when the knowledge exists, it may be disregarded, as in the case of the dredge spoil dumping onto the Abbot Point and Caley Valley wetlands in Australia, which is a habitat of more than 40,000 water-birds (Australian Marine Conservation Society, 2014), despite lessons learned in the Mississippi and other coastal wetlands.

Cumulative pressures change both the state of the environment (e.g., anoxia) and the state of the ecosystem (e.g., loss of saltmarsh, mangrove, and seagrasses). Coastal wetlands provide ecosystem services, such as regulatory services for water quality, coastal protection, carbon sequestration and denitrification, as well as supporting services such as habitat for a wide variety of fauna. The loss of vegetation of the coastal wetlands, represents a loss of a wide range of ecosystem services. There is a decrease in provisioning ecosystem services, e.g., timber from mangroves, seafood yield from the wetland, and also from the adjacent sea; supporting ecosystem services, e.g., oxygenation from seagrasses, nursery services, denitrification, carbon sequestration, and habitat for migrating wildfowl; regulating ecosystem services, e.g., water purification and natural hazard protection, e.g., floods, storm surge, and tsunamis cultural ecosystem services, such as loss of traditional lifestyles and artisanal fisheries.

However, there are some 'bright-spots.' Awareness and recognition of the value and importance of coastal wetlands is improving, and some nations are now developing ambitious management plans. In particular, the protecting ecosystem service of coastal wetlands gained recognition after the 2004 Banda Aceh tsunami (Spalding et al., 2014). Some of these efforts are transdisciplinary and bring together scientists, policy makers and environmental managers, as in the case of the Huang $\mathrm{He}$ (Yellow River) delta and coastal wetlands management plan (Wohlfart et al., 2016).

This is also the case for mangrove wetlands. Papua New Guinea is implementing the UN-REDD+ mechanism (the United Nations Reducing Emissions from Deforestation and forest Degradation plus Sustainable Forest Management, Conservation of Forests, Enhancement of carbon sinks), (Grussu et al., 2014). This aims to decrease emissions (e.g., from slash and burn deforestation) and enhance forest carbon-sequestration. The remote-sensing methodology detailed by Hamilton and Friess (2018), could be used for monitoring to support payment for ecosystem services such as REDD+.

The emphasis of this article has been direct pressures rather indirect, but both will affect the future of wetlands. Coastal 


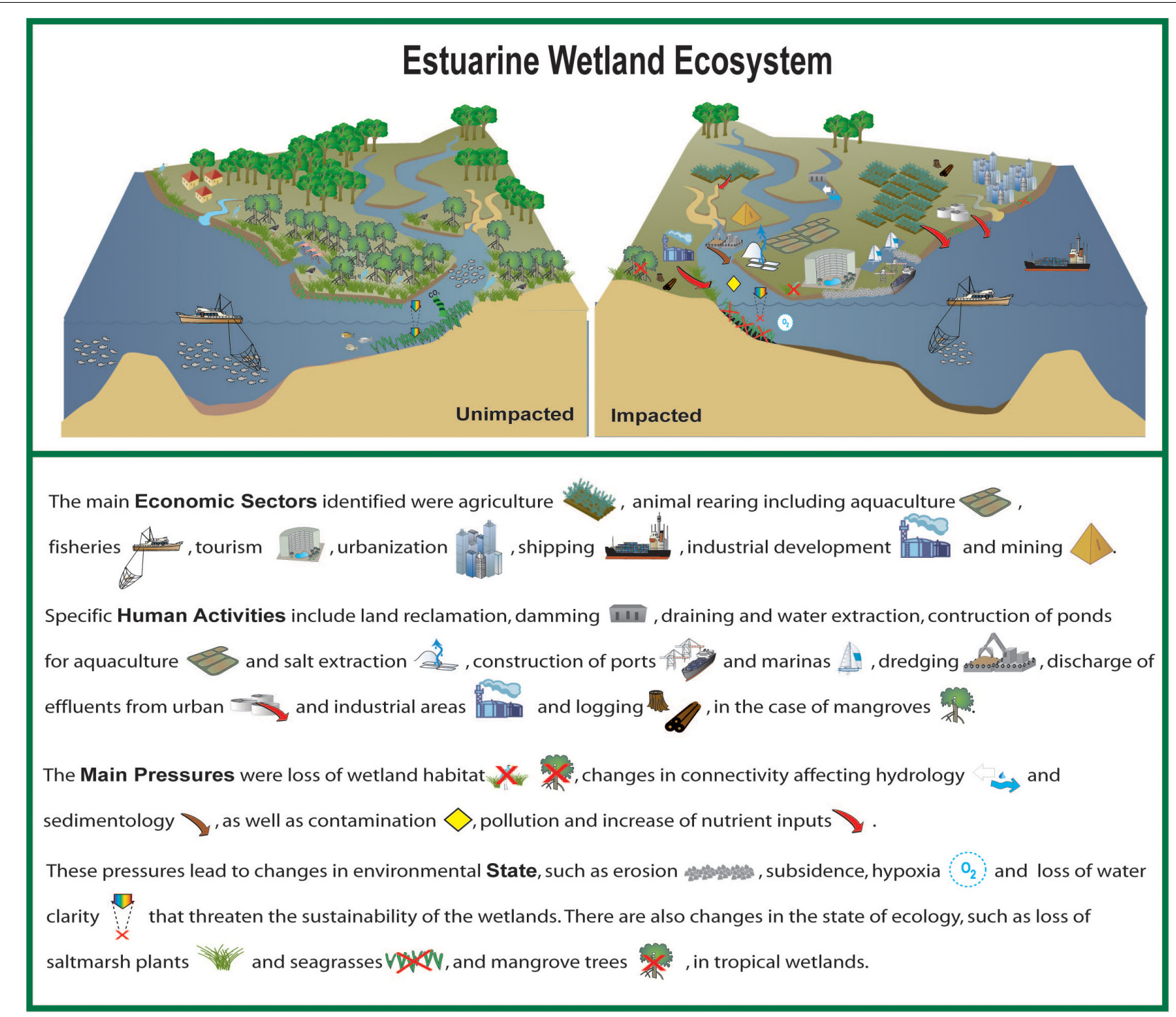

FIGURE 2 | Conceptual diagram summarising the findings, showing an estuarine wetland ecosystem in an unimpacted and impacted state. Symbols are courtesy of the Integration and Application Network, University of Maryland Center for Environmental Science (https://www.umces.edu/ian/search). (Credit: Sonia Cristina).

wetlands, mangrove forests, saltmarshes and seagrasses are particularly effective at sequestering carbon, as illustrated by the Papua New Guinea mangroves. It is important to consider both historical and contemporary environmental factors to better understand this regulating ecosystem service of coastal wetlands (Witman, 2017). Marshes, seagrass meadows, and mangroves are some of the ecosystems that sequester carbon most efficiently and store large amounts of carbon dioxide as "blue" carbon (Lovelock and Duarte, 2019; Cragg et al., 2020). Conservation of coastal wetlands can therefore contribute to the mitigation and adaptation to climate change (Neubauer and Verhoeven, 2019; Serrano et al., 2019). However, the Blue Carbon potential of coastal wetland restoration varies with inundation and rainfall (Negandhi et al., 2019) as well as management approaches (O'Connor et al., 2020). Degraded coastal wetlands could potentially be re-naturalized to promote an increase in carbon sequestration, as well as additional and valuable ecosystem services, such as denitrification and halophyte cultivation, for example Salicornia.

We conclude this overview by highlighting the importance of coastal wetlands both ecologically and economically. They provide an important buffer between land and sea in the context of sea-level rise and climate change. They are important cogs in the biogeochemical cycles, providing exceptional services such as denitrification and carbon sequestration. The ecosystem services that they provide are consistently underestimated leading to irreversible land-use changes that ultimately destroy the wetlands and impact human welfare. The conservation and ecosystem-based management of coastal wetlands will contribute to several of the United Nations Sustainable Development Goals, SDG, in particular, 2, 3, 6, 12, 13, 14, 15 but also $1,4,8,11$. 


\section{AUTHOR CONTRIBUTIONS}

AN wrote several sections and edited the entire manuscript. JI wrote Mida Creek, mangroves and edited the entire manuscript for submission. SoC wrote Ria Formosa lagoon and produced the conceptual diagram. GP wrote the Bahia Blanca estuary. RT wrote the Mississippi River. DA wrote the Sunderbans mangroves. SiC wrote the Gulf of Papua mangroves. YLi, CT, YLu, and HZ wrote the Yellow River delta wetland. RR wrote Vembanad Lake. DF wrote Polar coastal wetlands and Mackenzie-Beaufort coastal wetland. CS and BB wrote Bizerte lagoon and Ichkeul Lake. SG wrote Yangtze coastal wetlands. RP wrote Venice lagoon. HK and DT wrote Chesapeake Bay. NN and CK wrote Mekong delta wetlands. $\mathrm{AB}$ and RL wrote Malanza coastal lagoon.

\section{FUNDING}

JI was funded by the European Union's Horizon 2020 Research and Innovation Programme under grant agreement no. 678193 (CERES, Climate Change and European Aquatic Resources) ; CERES project funded this article. AN was funded by a Chinese Academy of Sciences (CAS-YIC) scholarship and an SKLECECNU project 111 scholarship. SoC was funded by Fundação

\section{REFERENCES}

Abecasis, D., Bentes, L., and Erzini, K. (2009). Home range, residency and movements of Diplodus sargus and Diplodus vulgaris in a coastal lagoon: connectivity between nursery and adult habitats. Estuar. Coast. Shelf S. 85, 525-529. doi: 10.1016/j.ecss.2009.09.001

Ahmad, I. U., Greenwood, C. J., Barlow, A. C. D., Islam, M. A., Hossain, A. N. M., Khan, M. M. H., et al. (2009). Bangladesh Tiger Plan 2009-2017. Dhaka: Bangladesh Forest Department, 46.

Ahmed, N., and Troell, M. (2010). Fishing for prawn larvae in Bangladesh: an important coastal livelihood causing negative effects on the environment. Ambio 39, 20-29. doi: 10.1007/s13280-009-0002-y

Alber, M. A. (2002). Conceptual model of estuarine freshwater inflow management. Estuaries 25, 1246-1261. doi: 10.1007/bf02692222

Aller, R. C., Blair, N. E., and Brunskill, G. J. (2008). Early diagenetic cycling, incineration, and burial of sedimentary organic carbon in the central Gulf of Papua (Papua New Guinea). J. Geophys. Res-Earth. 113:F01S09.

Almeida, C., and Soares, F. (2012). Microbiological monitoring of bivalves from the Ria Formosa Lagoon (south coast of Portugal): a 20 years of sanitary survey. Mar. Pollut. Bull. 64, 252-262. doi: 10.1016/j.marpolbul.2011.11.025

Almeida, L. P., Vousdoukas, M. V., Ferreira, Ó, Rodrigues, B. A., and Matias, A. (2012). Thresholds for storm impacts on an exposed sandy coastal area in southern Portugal. Geomorphology 143-144, 3-12. doi: 10.1016/j.geomorph. 2011.04.047

Alongi, D. M. (1995). Decomposition and recycling of organic matter in muds of the Gulf of Papua, northern Coral Sea. Cont. Shelf Res. 15, 1319-1337. doi: 10.1016/0278-4343(94)00087-4

Alongi, D. M. (2014). Carbon cycling and storage in mangrove forests. Annu. Ver. Mar. Sci. 6, 195-219. doi: 10.1146/annurev-marine-010213-135020

Aníbal, J., Gomes, A., Mendes, I., and Moura, D. (eds) (2019). Ria Formosa: Challenges of a Coastal Lagoon in a Changing Environment, 1st Edn. Faro: University of Algarve.

Anon (2016). Ramsar Sites in Kerala. Available online at: https://www.researchgate. net/file.PostFileLoader.html?id=57879561ed99e1c4f36f3857\&assetKey=AS\% 3A383745195560961\%401468503392919 (accessed August 8, 2016).

Arnaud-Fassetta, G., Bertrand, F., Costa, S., and Davidson, R. (2006). The western lagoon marshes of the Ria Formosa (Southern Portugal): sediment-vegetation para a Ciência e a Tecnologia (FCT) Scientific Employment Stimulus Programme (CEECIND/01635/2017). This work received additional support through FCT's strategic projects (UID/MAR/00350/2019CIMA). DF was funded by Natural Resources Canada contribution no. 20200070. AB was funded by Fundação para a Ciência e a Tecnologia (FCT) Scientific Employment Stimulus Programme (CEECIND/00095/2017). This work received additional support through FCT's strategic projects (UID/MAR/04292/2019).

\section{ACKNOWLEDGMENTS}

The authors acknowledge the support and contribution of Future Earth Coasts (FEC), Integrated Marine Biosphere Research (IMBeR), Future Earth Oceans Knowledge-Action Network, and Scientific Committee on Oceanic Research (SCOR).

\section{SUPPLEMENTARY MATERIAL}

The Supplementary Material for this article can be found online at: https://www.frontiersin.org/articles/10.3389/fevo.2020.00144/ full\#supplementary-material

dynamics, long-term to short-term changes and perspective. Cont. Shelf Res. 26, 363-384. doi: 10.1016/j.csr.2005.12.008

Asha, C. V., Cleetus, R., Suson, P. S., and Bijoy Nandan, S. (2015). Environmental factors structuring the fish assemblage distribution and production potential in Vembanad estuarine system. India. Int. J. Mar. Sci. 5, $1-13$.

Australian Marine Conservation Society (2014). The Values of the Caley Valley Wetlands. South Brisbane QLD: Australian Marine Conservation Society.

Bahar, M. M., and Reza, S. M. (2010). Hydrochemical characteristics and quality assessment of shallow groundwater in a coastal area of Southwest Bangladesh. Environ. Earth Sci. 61, 1065-1073. doi: 10.1007/s12665-0090427-4

Bai, J. H., Xiao, R., Zhang, K. J., and Gao, H. F. (2012). Arsenic and heavy metal pollution in wetland soils from tidal freshwater and Saltmarshes before and after the flow-sediment regulation regime in the Yellow River Delta. China. J. Hydrol. 450, 244-253. doi: 10.1016/j.jhydrol.2012.05.006

Barber, D. G., Lukovich, J. V., Keogak, J., Baryluk, S., Fortier, L., and Henry, G. H. R. (2008). The changing climate of the Arctic. Arctic 61, 7-26.

Barbier, E. B. (2016). The protective service of mangrove ecosystems: a review of valuation methods. Mar. Pollut. Bull. 109, 676-681. doi: 10.1016/j.marpolbul. 2016.01.033

Barbier, E. B., Koch, E. W., Silliman, B. R., Hacker, S. D., Wolanski, E., Primavera, J., et al. (2008). Coastal ecosystem-based management with nonlinear ecological functions and values. Science 319, 321-323.

Barkay, T., Kroer, N., and Pulain, A. J. (2011). Some like it cold: microbial transformations of mercury in polar regions. Polar Res. 30:15469. doi: 10.3402/ polar.v30i0.15469

Barker, B., Lamb, L., David, B., Skelly, R., and Korokai, K. (2015). Dating of in situ longhouse (dubu daima) posts in the Kikori River delta: refining chronologies of island village occupation in the lower Kikori River delta, Papua New Guinea. Quatern. Int. 385, 27-38. doi: 10.1016/j.quaint.2015.04.003

Bebianno, M. J. (1997). Effect of pollutants in the Ria Formosa lagoon, Portugal. Sci. Total Environ. 171, 107-115. doi: 10.1016/0048-9697(95)04672-9

Bebianno, M. J., Patrícia, P., Ângela, S., Belisandra, L., and Alice, N. (2019). Ria Formosa: Challenges of a Coastal Lagoon in a Changing Environment, 1st Edn, eds J. Aníbal, A. Gomes, I. Mendes, and D. Moura (Faro: University of Algarve), 109-123. 
Becket, L. H., Andrew, H. B., and Michael, S. K. (2016). Tidal marshes are not keeping up with sea-level rise. PLoS One 11:e0159753. doi: 10.1371/journal. pone. 0159753

Béjaoui, B., Ferjani, D., Zaaboub, N., and Chapelle, A. (2010). Seasonal hydrobiological characterization of the Bizerte Lagoon (Tunisia). J. Water Sci. 23, 215-232.

Béjaoui, B., Harzallah, A., Moussa, M., Chapelle, A., and Solidoro, C. (2008). Analysis of hydrobiological pattern in the Bizerte lagoon (Tunisia). Estuar. Coast Shelf. Sci. 80, 121-129. doi: 10.1016/j.ecss.2008.07.011

Ben Omrane, B., Elbour, I., Belhassen, M., Mraouna, M., Mejri, R., Béjaoui, S., et al. (2010). Distribution spatiale des Vibrionaceae dans les sédiments lagunaires (la lagune de Bizerte, Nord Tunisie). Rev. Microbiol. Indus. San. Environ. 4, 83-94.

Ben Rejeb-Jenhani, A., Kartas, F., Le moalle, J., and Amblard, C. (1991). Phytoplancton du lac Ichkeul (Tunisie): composition, structure et activité photosynthétique. Int. Revue Ges. Hydrobiol. 75, 111-127.

Bianchi, T. S., and Allison, M. A. (2009). Large-river delta-front estuaries as natural "recorders" of global environmental change. Proc. Natl. Acad. Sci. U.S.A. 106, 8085-8092. doi: 10.1073/pnas.0812878106

Binder, C. R., Hinkel, J., Bots, P. W. G., and Pahl-Wostl, C. (2013). Comparison of frameworks for analyzing social- ecological systems. Ecol. Soc. 18, 26.

Biswas, S. R., Choudhury, J. K., Nishat, A., and Rahman, M. (2007). Do invasive plants threaten the Sundarbans mangrove forest of Bangladesh? J. Forest. Ecol. Manag. 245, 1-9. doi: 10.1016/j.foreco.2007.02.011

Blasco, S., Bennett, R., Brent, T., Burton, M., Campbell, P., Carr, E., et al. (2013). 2010 State of Knowledge: Beaufort Sea Seabed Geohazards Associated with Offshore Hydrocarbon Development. Ottawa: Natural Resources Canada, 340. doi: $10.4095 / 292616$

Bolton, B. R. (2009). “The Fly River, Papua New Guinea: environmental studies in an impacted tropical river system," in Developments in Environmental Science, Vol. 9, ed. B. R. Bolton (Amsterdam: Elsevier), 617.

Botté, S. E., Freije, R. H., and Marcovecchio, J. E. (2007). Dissolved heavy metal (Cd. $\mathrm{Pb}$. Cr. Ni) concentrations in surface water and porewater from Bahía Blanca Estuary Tidal Flats. B Environ. Contam. Tox. 79, 415-421. doi: 10.1007/s00128007-9231-6

Bousquet, B. (1988). Rapport de Mission du Parc National de l'Ichkeul et autres aires protegees de Tunisie septentrionale et centrale. Paris: MAB-UNESCO et Fonds du Patrimoine Mondial.

Brendel, A. S., Dutto, M. S., Menéndez, M. C., Huamantinco Cisneros, M. A., and Piccolo, M. C. (2017). Wind pattern change along a period of coastal occurrence variation of a stinging medusa on a SW Atlantic beach. Anu. Inst. Geociencias 40,303-315. doi: 10.11137/2017_3_303_315

Briant, N., Bancon-Montigny, C., Elbaz-Poulichet, F., Freydier, R., Delpoux, S., and Cossa, D. (2013). Trace elements in the sediments of a large Mediterranean marina (Port Camargue, France): levels and contamination history. Mar. Pollut. Bull. 73, 78-85. doi: 10.1016/j.marpolbul.2013.05.038

Brito, A. C., Newton, A., Tett, P., and Fernandes, T. F. (2012). How will shallow coastal lagoons respond to climate change? A modelling investigation. Estuar. Coast. Shelf Sci. 112, 98-104. doi: 10.1016/j.ecss.2011.09.002

Brown, S., Nicholls, R. J., Lázár, A. N., Hornby, D. D., Hill, C., Harza, S.,et al. (2018). What are the implications of sea-level rise for a $1.5,2$, and $3^{\circ} \mathrm{C}$ rise in global mean temperatures in the Ganges-Brahmaputra-Meghna, and other vulnerable deltas? Reg. Environ. Change 18, 1829-1842. doi: 10.1007/s10113-018-1311-0

Bryan, J., Shearman, P., Aoro, G., Wavine, F., and Zetty, J. (2015). "The current state of PNG's forests and changes between 2002 and 2014," in The State of the Forests of Papua New Guinea 2014: Measuring change over the period 2002-2014, eds J. E. Bryan and P. L. Shearman (Port Moresby: University of Papua New Guinea), 7-42.

Bulseco, A. N., Giblin, A. E., Tucker, J., Murphy, A. E., Sanderman, J., HillerBittrolff, K., et al. (2019). Nitrate addition stimulates microbial decomposition of organic matter in salt marsh sediments. Glob. Change Biol. 25, 3224-3241. doi: $10.1111 /$ gcb.14726

Bureau Central d'Etudes pour les Equipements d'Outre-Mer [BCEOM], FresinusConsult, CESalzgitter, and STUDI (1995). (Etude)pour la sauvegarde du Parc National de l'Ichkeul. Rapport de 3èmepartie: Mesures et études spécifiques/Ministère de l'Environnement et de l'Aménagement duTerritoire. Tunis: ANPE, 421.
Burn, C. R., and Kokelj, S. V. (2009). The environment and permafrost of the Mackenzie Delta area. Permafrost Periglac. 20, 83-105. doi: 10.1002/ppp.655

Byers, M. (2016). Arctic Oil: Canada's Chance to Get it Right. Social Sciences and Humanities Research Council, Canada. Knowledge Synthesis Report, 57. Available online at: https://byers.typepad.com/files/michaelbyers_ knowledgesynthesisreport_arcticoil_18may2016.pdf (accessed May 12, 2020).

Cabaço, S., Machás, R., and Santos, R. (2009). Individual and population plasticity of the seagrass Zostera noltii along a vertical intertidal gradient. Estuar. Coast. Shelf S. 82, 301-308. doi: 10.1016/j.ecss.2009.01.020

Cahoon, D. R. (2007). Factors Affecting Coastal Wetland Loss and Restoration Synthesis of U.S. Geological Survey Circular 1316, ed. S. W. Phillips (Reston, VA: U.S. Geological Survey), 50-54.

Canonico, G. C., Arthington, A., McCrary, J. K., and Thieme, M. L. (2005). The effects of introduced tilapias on native biodiversity. Aquatic Conserv. 15, 463-483. doi: 10.1002/aqc.699

Cao, Z., Liu, X., Zhang, X., Chen, L., Liu, S., and Hu, Y. (2012). Short-term effects of diesel fuel on rhizosphere microbial community structure of native plants in Yangtze estuarine wetland. Environ. Sci. Pollut. R. 19, 2179-2185. doi: 10.1007/s11356-011-0720-0

Carrasco, A. R., and Matias, A. (2019). "Backbarrier shores along the Ria Formosa Lagoon," in Ria Formosa: Challenges of a Coastal Lagoon in a Changing Environment, 1st Edn, eds J. Aníbal, A. Gomes, I. Mendes, and D. Moura (Faro: University of Algarve), 17-28.

Casagranda, C., Dridi, M. S., and Francois Boudouresque, C. (2006). Abundance, population structure and production of macro-invertebrate shredders in a Mediterranean brackish lagoon, Lake Ichkeul, Tunisia. Estuar. Coast. Shelf S. 66, 437-446. doi: 10.1016/j.ecss.2005.10.005

CEGIS (2007). Effect of Cyclone Sidr on the Sundarbans a Preliminary Assessment. Dhaka: Center for Environmental and Geographic Information Services CEGIS, $1-8$.

Ceia, F. R., Patrício, J., Marques, J. C., and Dias, J. M. (2010). Coastal vulnerability in barrier islands: the high risk areas of the Ria Formosa (Portugal) system. Ocean Coast. Manage. 53, 478-486. doi: 10.1016/j.ocecoaman.2010.06.004

Chen, H., Li, B., Hu, J., Chen, J., and Wu, J. (2007). Effects of Spartina alterniflora invasion on benthic nematode communities in the Yangtze Estuary. Mar. Ecol. Prog. Ser. 336, 99-110. doi: 10.3354/meps336099

Chen, J., Wang, S. Y., and Mao, Z. P. (2011). Monitoring wetland changes in Yellow River Delta by remote sensing during 1976-2008. Prog. Geog. 30, 585-592.

Chen, Z., Li, B., Zhong, Y., and Chen, J. (2004). Local competitive effects of introduced Spartina alterniflora on Scirpus mariqueter at Dongtan of Chongming Island, the Yangtze River estuary and their potential ecological consequences. Hydrobiologia 528, 99-106. doi: 10.1007/s10750-004-1888-9

Cheng, H. Q., and Chen, J. Y. (2016). Influences of Sea Level Rise on the Changjiang Estuary. Beijing: China. Science Press, 414.

Chesapeake Bay Program [CBP] (2012). Wetlands. Available online at: http:// chesapeakebay.net/issues/issue/wetlands (accessed August 28, 2016).

Church, J. A., Clark, P. U., Cazenave, A., Gregory, J. M., Jevrejeva, S., Levermann, A., et al. (2014). Sea-level rise by 2100. Science 342:1445.

Coastal Protection Restoration Authority [CPRA] (2017). Louisiana's Comprehensive Master Plan for a Sustainable Coast 2017. Baton Rouge: CPRA.

Costanza, R., Farber, S. C., and Maxwell, J. (1989). Valuation and management of wetland ecosystems. Ecol. Econ. 1, 335-361. doi: 10.1016/0921-8009(89)9 0014-1

Costanza, R., Perez-Maqueo, O., Martinez, M. L., Sutton, P., Anderson, S. J., and Mulder, K. (2008). The value of coastal wetlands for hurricane protection. Ambio 37, 241-248.

Couture, N. J., Irrgang, A., Pollard, W., Lantuit, H., and Fritz, M. (2018). Coastal erosion of permafrost soils along the Yukon Coastal Plain and fluxes of organic carbon to the Canadian Beaufort Sea. J. Geophys. Res. Biogeosci. 123, 406-422. doi: 10.1002/2017JG004166

Couvillion, B. R., Beck, H., Schoolmaster, D., and Fischer, M. (2017). Land area change in coastal Louisiana 1932 to 2016: US Geological Survey Scientific Investigations Map 3381. Reston, VA: US Geological Survey, 16.

Cragg, S. M. (1983). “The mangrove ecosystem of the Purari Delta," in The Purari - Tropical Environment of a High Rainfall River Basin, ed. T. Petr (Dordrecht: Springer Netherlands), 295-324. doi: 10.1007/978-94-009-7263-6_16 
Cragg, S. M., Friess, D. A., Gillis, L. G., Trevathan-Tackett, S. M., Terrett, O. M., Watts, J. E., et al. (2020). Vascular plants are globally significant contributors to marine carbon fluxes and sinks. Ann. Rev. Mar. Sci. 12, 469-497. doi: 10.1146/ annurev-marine-010318-095333

Cravo, A., Fernandes, D., Damião, T., Pereira, C., and Reis, M. P. (2015). Determining the footprint of sewage discharges in a coastal lagoon in SouthWestern Europe. Mar. Pollut. Bull. 96, 197-209. doi: 10.1016/j.marpolbul.2015. 05.029

Cui, B. S., Yang, Q. C., Yang, Z. F., and Zhang, K. J. (2009). Evaluating the ecological performance of wetland restoration in the Yellow River Delta. China. Ecol. Eng. 35, 1090-1103. doi: 10.1016/j.ecoleng.2009.03.022

Cui, L., Ge, Z., Yuan, L., and Zhang, L. (2015). Vulnerability assessment of the coastal wetlands in the Yangtze Estuary, China to sea-level rise. Estuar. Coast. Shelf Sci. 156, 42-51. doi: 10.1016/j.ecss.2014.06.015

Cunha, A. H., Assis, J. F., and Serrão, E. A. (2013). Seagrasses in Portugal: a most endangered marine habitat. Aquat. Bot. 104, 193-203. doi: 10.1016/j.aquabot. 2011.08.007

Dahdouh-Guebas, F., Kairo, J. G., Koedam, N., and Mathenge, C. (2000). Utilization of mangrove wood products around Mida Creek (Kenya) amongst subsistence and commercial users. Econ. Bot. 54, 513-527. doi: 10.1007/ bf02866549

Darby, F. A., and Turner, R. E. (2008). Below- and aboveground biomass of Spartina alterniflora: response to nutrient addition in a Louisiana salt marsh. Estuar. Coasts 31, 326-334. doi: 10.1007/s12237-008-9037-8

Dasgupta, S., Sobhan, I., and Wheeler, D. (2017). The impact of climate change and aquatic salinization on mangrove species in the Bangladesh Sundarbans. Ambio 46, 680-694. doi: 10.1007/s13280-017-0911-0

David, B., Aplin, K., Petchey, F., Skelly, R., Mialanes, J., Jones-Amin, H., et al. (2015). Kumukumu 1, a hilltop site in the Aird Hills: Implications for occupational trends and dynamics in the Kikori River delta, south coast of Papua New Guinea. Quatern. Int. 385, 7-26. doi: 10.1016/j.quaint.2014. 06.058

Deegan, L. A., Johnson, D. S., Warren, R. S., Peterson, B. J., Fleeger, J. W., Fagherazzi, S., et al. (2012). Coastal eutrophication as a driver of salt marsh loss. Nature 490, 388-392. doi: 10.1038/nature11533

Dennis, D. M., Pitcher, C. R., and Skewes, T. D. (2001). Distribution and transport pathways of Panulirus ornatus (Fabricius, 1776) and Panulirus spp. larvae in the Coral Sea, Australia. Mar. Fresh. Res. 52, 1175-1185. doi: 10.1071/MF01186

DGPA (2012). Annuaire Statistique de la Direction Générale de la Pêche et de l'Aquaculture. Tunis: DGPA.

Ding, P. X. (2016). Evolution Trend and Vulnerability Assessment of Typical Coastal zones in China Under the Influence of Climate Change. Beijing: China Science Press.

Dionisio, L. P. C., Rheinheimer, G., and Borrego, J. J. (2000). Microbiological pollution of Ria Formosa (south of Portugal). Mar. Pollut. Bull. 40, 186-193.

Doody, J. P. (2004). 'Coastal squeeze'-an historical perspective. J. Coast. Conser. $10,129-138$

Duke, N. C., Ball, M. C., and Ellison, J. C. (1998). Factors influencing biodiversity and distributional gradients in mangroves. Global Ecol. Biogeogr. 7, 27-47. doi: $10.2307 / 2997695$

Duy, N. B., Clauss, K., Cao, S., Naeimi, V., Kuenzer, C., and Wagner, W. (2015). Mapping rice seasonality in the mekong Delta with Multi-Year Envisat ASAR WSM Data. Remote Sens. 7, 15868-15893. doi: 10.3390/rs7121 5808

El Mahrad, B., Abalansa, S., Newton, A., Icely, J. D., Snoussi, M., and Kacimi, I. (2020). Social-environmental analysis for the management of coastal lagoons in North Africa. Front. Environ. Sci. 8:37. doi: 10.3389/fenvs.2020.00037

Elliott, M., and Whitfield, A. K. (2011). Challenging paradigms in estuarine ecology and management. Estuar. Coast. Shelf S. 94, 306-314. doi: 10.1016/j.ecss.2011. 06.016

Elliott, M., Burdon, D., Atkins, J. P., Borja, A., Cormier, R., De Jonge, V. N., et al. (2017). “And DPSIR begat DAPSI (W) R (M)!”-A unifying framework for marine environmental management. Mar. Pollut. Bull. 118, 27-40. doi: 10.1016/j.marpolbul.2017.03.049

Elliott, M., Cutts, N. D., and Trono, A. (2014). A typology of marine and estuarine hazards and risks as vectors of change: a review for vulnerable coasts and their management. Ocean Coast. Manag. 93, 88-99. doi: 10.1016/j.ocecoaman.2014. 03.014
Emmerton, C. A., Lesack, L. F. W., and Marsh, P. (2007). Lake abundance, potential water storage, and habitat distribution in the Mackenzie River delta, western Canadian Arctic. Water Resour. Res. 43:W05419. doi: 10.1029/2006WR005139

Essid, N., Mahmoudi, E., Boufahja, F., Dellali, M., Beyrem, H., and Aissa, P. (2008). Impact des pseudo-féces de moules sur la densité des bactéries hétérotrophes dans le secteur mytilicole de la lagune de Bizerte (Tunisie). Rev. Sci. Equ. 20, 383-392. doi: 10.7202/016912ar

Facca, C., Ceoldo, S., Pellegrino, N., and Sfriso, A. (2014). Natural recovery and planned intervention in coastal wetlands: Venice Lagoon (Northern Adriatic Sea. Italy) as a case study. Sci. World J. 968618, 1-15. doi: 10.1155/2014/968618

Félix, P. M., Chainho, P., Lima, R. F., Costa, J. L., Almeida, A. J., Domingos, I., et al. (2017). Mangrove fish of São Tomé Island (Gulf of Guinea): new occurrences and habitat usage. Mar. Freshw. Res. 68, 123-130.

Fertouna-Bellakhal, M., Dhib, A., Béjaoui, B., Turki, S., and Aleya, L. (2014). Driving factors behind the distribution of dinocyst composition and abundance in surface sediments in a western Mediterranean coastal lagoon: report from a high resolution mapping study. Mar. Pollut. Bull. 84, 1-2.

Flaherty, M., Szuster, B., and Miller, P. (2000). Low salinity inland shrimp farming in Thailand. Ambio 29, 174-179. doi: 10.1579/0044-7447-29.3.174

Forbes, D. L. (ed.). (2011). State of the Arctic Coast 2010: Scientific Review and Outlook. International Arctic Science Committee, Land-Ocean Interactions in the Coastal Zone, Arctic Monitoring and Assessment Programme, International Permafrost Association. Geesthacht: Helmholtz-Zentrum Geesthacht. Available online at: http://library.arcticportal.org/1277/1/state_of_the_arctic_coast_ 2010.pdf

Forbes, D. L. (2019). "Arctic deltas and estuaries: a Canadian perspective," in Coasts and Estuaries: the Future, eds E. Wolanski, J. W. Day, M. Elliott, and R. Ramachandran (Burlington: Elsevier), 123-147. doi: 10.1016/B978-0-12814003-1.00008-3

Forbes, D. L., and Hansom, J. D. (2011). "Polar coasts," in Treatise on Estuarine and Coastal Science, Vol. 3, eds E. Wolanski and D. S. McLusky (Waltham, MA: Academic Press/Elsevier), 245-283. doi: 10.1016/b978-0-12-374711-2.00312-0

Forbes, D. L., Manson, G. K., Whalen, D. J. R., Couture, N. J., and Hill, P. R. (2014). "Coastal products of marine transgression in cold-temperate and high-latitude coastal plain settings: Gulf of St Lawrence and Beaufort Sea," in Sedimentary Coastal Zones from High to Low Latitudes: Similarities and Differences, Special Publication 388, eds I. P. Martini and H. R. Wanless (London: Geological Society), 131-163. doi: 10.1144/SP388.18

Frank, C., Kairo, J. G., Bosire, J. O., Mohamed, M. O., Dahdouh-Guebas, F., and Koedam, N. (2017). Involvement, knowledge and perception in a natural reserve under participatory management: Mida Creek, Kenya. Ocean Coast. Manag. 142, 28-36. doi: 10.1016/j.ocecoaman.2017.03.009

Frazier, D. E. (1967). Recent deltaic deposits of the Mississippi River: their development and chronology. Trans. Gulf Coast Soc. Geol. Trans. 17, 287-315.

Freije, R. H., Spetter, C. V., Marcovecchio, J. E., Popovich, C. A., Botté, S. E., Negrín, V., et al. (2008). "Water chemistry and nutrients in the Bahía Blanca Estuary," in Perspectives on Integrated Coastal Zone Management in South America, eds R. Neves, J. Baretta, and M. Mateus (Lisboa: IST Press), 243-256.

Fritz, M., Vonk, J. E., and Lantuit, H. (2017). Commentary: collapsing Arctic coastlines. Nat. Clim. Change 7, 6-7. doi: 10.1038/nclimate3188

Frusher, S. D. (1983). "The ecology of juvenile penaeid prawns, mangrove crab (Scylla serrata) and the giant freshwater prawn (Macrobrachium rosenbergii) in the Purari Delta," in The Purari - Tropical Environment of a High Rainfall River Basin, ed. T. Petr (The Hague: Dr W. Junk Publishers), 341-353. doi: 10.1007/978-94-009-7263-6_18

Gang, P. O., and Agatsiva, J. L. (1992). The current status of mangroves along the Kenyan Coast: a case study of Mida Creek mangroves based on remote sensing. The Ecology of Mangrove and Related Ecosystems. Hydrobiologia 247, 29-36. doi: 10.1007/978-94-017-3288-8_4

Gao, S. (2007). Modeling the growth limit of the Changjiang Delta. Geomorphology 85, 225-236. doi: 10.1016/j.geomorph.2006.03.021

Gao, S., Du, Y. F., Xie, W. J., Gao, W. H., Wang, D. D., and Wu, X. D. (2014). Environment-ecosystem dynamic processes of Spartina alterniflora saltmarshes along the eastern China coastlines. Sci. China Earth Sci. 57, 2567-2586. doi: 10.1007/s11430-014-4954-9

Gao, S., Jia, J. J., Yang, Y., Zhou, L., Wei, W., Mei, Y. J., et al. (2019). Obtaining typhoon information from sedimentary records in coastal-shelf waters. Haiyang Xuebao 41, 141-160. 
García-Marín, P., Cabaço, S., Hernández, I., Vergara, J. J., Silva, J., and Santos, R. (2013). Multi-metric index based on the seagrass Zostera noltii (ZoNI) for ecological quality assessment of coastal and estuarine systems in SW Iberian Peninsula. Mar. Pollut. Bull. 68, 46-54. doi: 10.1016/j.marpolbul.2012.12.025

Gari, S. R., Newton, A., and Icely, J. D. (2015). A review of the application and evolution of the DPSIR framework with an emphasis on coastal socialecological systems. Ocean Coast. Manag. 103, 63-67.

Gedan, K. B., Kirwan, M. L., Wolanski, E., Barbier, E. B., and Silliman, B. R. (2011). The present and future role of coastal wetland vegetation in protecting shorelines: answering recent challenges to the paradigm. Clim. Change 106, 7-29. doi: 10.1007/s10584-010-0003-7

Giosan, L., Syvitski, J., Constantinescu, S. D., and Day, J. (2014). Protect the world's deltas. Nature 516, 31-33. doi: 10.1038/516031a

Giubilato, E., Radomyski, A., Critto, A., Ciffroy, P., Brochot, C., Pizzol, L., et al. (2016). Modelling ecological and human exposure to POPs in Venice lagoon. Part I - Application of MERLIN-Expo tool for integrated exposure assessment. Sci. Total Environ. 565, 961-976. doi: 10.1016/j.scitotenv.2016.04.146

Glibert, P. M., Magnien, R., Lomas, M. W., Alexander, J., Tan, C., Haramoto, E., et al. (2001). Harmful algal blooms in the Chesapeake and coastal bays of Maryland. USA: comparison of 1997, 1998, and 1999 events. Estuaries 24, 875-883.

Goni, M. A., Monacci, N., Gisewhite, R., Ogston, A., Crockett, J., and Nittrouer, C. (2006). Distribution and sources of particulate organic matter in the water column and sediments of the Fly River Delta, Gulf of Papua (Papua New Guinea). Estuar. Coast. Shelf Sci. 69, 225-245. doi: 10.1016/j.ecss. 2006.04.012

Gopal, B., and Chauhan, M. (2006). Biodiversity and its conservation in the Sundarban mangrove ecosystem. Aquat. Sci. 68, 338-354. doi: 10.1007/s00027006-0868-8

Granek, E. F., Compton, J. E., and Phillips, D. L. (2009). Mangrove-exported nutrient incorporation by sessile coral reef invertebrates. Ecosystems 12, 462472. doi: 10.1007/s10021-009-9235-7

Grosse, G., Goetz, S., McGuire, A. D., Romanovsky, V. E., and Schuur, A. A. G. (2016). Changing permafrost in a warming world and feedbacks to the Earth system. Environ. Res. Lett. 11:040201. doi: 10.1088/1748-9326/11/4/040201

Grussu, G., Attorre, F., Mollicone, D., Dargusch, P., Guillet, A., and Marchetti, M. (2014). Implementing REDD plus in Papua New Guinea: can biodiversity indicators be effectively integrated in PNG's National Forest Inventory? Plant Biosyst. 148, 519-528. doi: 10.1080/11263504.2014. 900131

Guillet, F., and Mermet, L. (2017). How to make biodiversity knowledge compelling? The case of mosquito control implementation in the Camargue (France). Environ. Sci. Policy (in press). doi: 10.1016/j.envsci.2017. 05.004

Gwyther, D. (1983). "The importance of the Purari River Delta to the prawn trawl fishery of the Gulf of Papua," in The Purari - Tropical Environment of a High Rainfall River Basin, ed. T. Petr (The Hague: Dr W. Junk Publishers), 355-365. doi: 10.1007/978-94-009-7263-6_19

Haldar, R., Khosa, R., and Gosain, A. K. (2019). Impact of anthropogenic interventions on the vembanad lake system. Water Res. Environ. Eng. 1, 9-29.

Hamilton, S. E., and Friess, D. A. (2018). Global carbon stocks and potential emissions due to mangrove deforestation from 2000 to 2012. Nat. Clim. Change 8, 240-244. doi: 10.1038/s41558-018-0090-4

Hoang, L. P., Biesbroek, R., Tri, V. P. D., Kummu, M., van Vliet, M. T. H., Leemans, R., et al. (2018). Managing flood risks in the Mekong Delta: How to address emerging challenges under climate change, and socioeconomic developments. Ambio 47, 635-649. doi: 10.1007/s13280-0171009-4

Hollis, G. E. (1986). The modelling and management of the internationally important wetland at Ek Garaet El Ichkeul, Tunisia. International Waterfowl Research Bureau. Spec. Publ. 7:121.

Hollis, G. E., Agnew, C. T., Battarbee, R. W., Chrismall, N., Fisher, R. C., Flower, R., et al. (1977). A Management Plan for the Proposed Park National de l'Ichkeul, Tunisia. Conserv. Rep. Ser. 11:240.

Hoq, M. E. (2007). An analysis of fisheries exploitation and management practices in Sundarbans mangrove ecosystem, Bangladesh. Ocean Coast. Manag. 50, 411-427. doi: 10.1016/j.ocecoaman.2006. 11.001
Hoq, M. E., Islam, M. N., Kamal, M., and Wahab, M. A. (2001). Abundance and seasonal distribution of Penaeus monodon postlarvae in the Sundarbans mangrove, Bangladesh. Hydrobiologia 457, 97-104.

Hoque, M. A., and Alam, S. M. K. (1995). "Post Farakka dry season surface and ground water conditions in the Ganges and vicinity," in Women for Water Sharing, ed. J. M. Hasna (Dhaka: Academic Publishers), 48-64.

Hossain, M. S., Dearing, J. A., Rahman, M. M., and Salehin, M. (2016). Recent changes in ecosystem services and human well-being in the Bangladesh coastal zone. Reg. Environ. Change 16, 429-443. doi: 10.1007/s10113-014-0748-z

Iftekhar, M. S. (2004). Environmental conscequences of oil pollution on the Bangladesh Sundarban: a brief review. ISME 3:11.

Iftekhar, M. S., and Saenger, P. (2007). Vegetation dynamics in the Bangladesh Sundarbans mangroves: a review of forest inventories. Wetl. Ecol. Manag. 16, 291-312. doi: 10.1007/s11273-007-9063-5

INCCA (2010). Climate Change and India: A 4 X 4 Assessment, a Sectoral and Regional Analysis for 2030s, Vol. 2. New Delhi: Ministry of Environment \& Forests, Government of India.

Inuvialuit Harvest Study Working Group (2003). Inuvialuit Harvest Study: Data and Methods Report 1988-1997. Inuvik: Joint Secretariat.

Irrgang, A. M., Lantuit, H., Gordon, R. R., Piskor, A., and Manson, G. K. (2019). Impacts of past and future coastal changes on the Yukon coast - threats for cultural sites, infrastructure, and travel routes. Arctic Sci. 5, 107-126. doi: 10. 1139/as-2017-0041

Islam, D. S. M., and Bhuiyan, M. A. H. (2018). Sundarbans mangrove forest of Bangladesh: causes of degradation and sustainable management options. Environ. Sustain. 1, 113-131. doi: 10.1007/s42398-018-0018-y

Islam, M. A., Mamun, A. Al, Hossain, F., Quraishi, S. B., Naher, K., Khan, R., et al. (2017). Contamination and ecological risk assessment of trace elements in sediments of the rivers of Sundarban mangrove forest, Bangladesh. Mar. Pollut. Bull. 124, 356-366. doi: 10.1016/j.marpolbul.2017. 07.059

Islam, M. N., and Al-Amin, M. (2019). The Rampal power plant, ecological disasters and environmental resistance in Bangladesh. Int. J. Environ. Stud. 76, 922-939. doi: 10.1080/00207233.2019.1662183

Islam, M. R. (2006). "Managing diverse land uses in coastal Bangladesh: institutional approaches," in Environment and Livelihoods in Tropical Coastal Zones, eds C. T. Hoanh, T. P. Tuong, J. W. Gowing, and B. Hardy (Manila: CAB International and International Rice Research Institute (IRRI)), 237-248. doi: 10.1079/9781845931070.0237

Islam, S. N. (2019). "Sundarbans a dynamic ecosystem: an overview of opportunities, threats and tasks," in The Sundarbans: A Disaster-Prone EcoRegion. Coastal Research Library, Vol. 30, ed. H. Sen (Cham: Springer), doi: 10.1007/978-3-030-00680-8_2

Islam, S. N., and Gnauck, A. (2009). Threats to the Sundarbans mangrove wetland ecosystems from transboundary water allocation in the Ganges Basin: a preliminary problem analysis. Int. J. Ecol. Econ. Stat. 13, 64-78.

Islam, S. N., Reinstädtler, S., and Gnauck, A. (2018). "Vulnerability of mangrove forests and wetland ecosystems in the Sundarbans natural world heritage site (Bangladesh)," in Threats to Mangrove Forests. Coastal Research Library, Vol. 25, eds C. Makowski and C. Finkl (Cham: Springer).

IUCN (1994). 1993 United Nations List of National Parks and Protected Areas. Gland: IUCN.

Jin, B., Fu, C., Zhong, J., Li, B., Chen, J., and Wu, J. (2007). Fish utilization of a salt marsh intertidal creek in the Yangtze River estuary, China. Estuar. Coast. Shelf S. 73, 844-852. doi: 10.1016/j.ecss.2007.03.025

Jungsberg, L., Turunen, E., Heleniak, T., Wang, S., Ramage, J., and Roto, J. (2019). Atlas of Population, Society and Economy in the Arctic. Nordregio Working Paper 2019:3. Stockholm: Nordregio, doi: 10.30689/WP2019:3.1403-2511

Kairo, J. G., Dahdouh-Guebas, F., Gwada, P. O., Ochieng, C., and Koedam, N. (2002). Regeneration status of mangrove forests in Mida Creek, Kenya: a compromised or secured future? Ambio 31, 562-568. doi: 10.1579/0044-744731.7.562

Kearney, M. S., Riter, C. A., and Turner, R. E. (2011). Freshwater diversions for marsh restoration in Louisiana: twenty-six years of changing vegetative cover and marsh area. Geophys. Res. Lett. 38:L16405. doi: 10.1029/2011GL047847

Kebede, A., Nicholls, R., Hanson, S., and Mokrech, M. (2010). Impacts of climate change and sea-level rise: a preliminary case study of Mombasa. Kenya. J. Coast. Res. 28, 8-19. doi: 10.2112/jcoastres-d-10-00069.1 
Kemp, W. M., Boynton, W. R., Adolf, J. E., Boesch, D. F., Boicourt, W. C., Brush, G., et al. (2005). Eutrophication of Chesapeake Bay: historical trends and ecological interactions. Mar. Ecol. Prog. Ser. 303, 1-29. doi: 10.3354/meps303001

Kennedy, C. J., and Barbier, E. B. (2016). The economic value of freshwater inputs to an estuarine fishery. Water Res. Econ. 13, 46-59. doi: 10.1016/j.wre.2015.11. 003

Khan, M. S., Haq, E., Huq, S., Rahman, A. A., Rashid, S. M. A., and Ahmed, H. (1994). Wetlands of Bangladesh. Dhaka: BCAS.

Kirui, K. B., Kairo, J. G., Bosire, J., Viergever, K. M., Rudra, S., Huxham, M., et al. (2013). Mapping of mangrove forest land cover change along the Kenya coastline using Landsat imagery. Ocean Coast. Manag. 83, 19-24. doi: 10.1016/ j.ocecoaman.2011.12.004

KNBS (2010). The 2009 Kenya Population and Housing Census Population Distribution by Administrative Unit, Vol. IA. Kenya: Kenya National Bureau of Statistics, 260.

Kokelj, S. V., and GeoNorth Limited (2002). Drilling Mud Sumps in the Mackenzie Delta Region: Construction, Abandonment and Past Performance. Yellowknife: Contract report to Department of Indian Affairs and Northern Development.

Kokelj, S. V., Lantz, T. C., Solomon, S., Pisaric, M. F. J., Keith, D., Morse, P., et al. (2012). Using multiple sources of knowledge to investigate northern environmental change: regional ecological impacts of a storm surge in the outer Mackenzie Delta, NWT. Arctic 65, 257-272.

Kokelj, S. V., Riseborough, D., Coutts, R., and Kanigan, J. C. N. (2010). Permafrost and terrain conditions at northern drilling-mud sumps: impacts of vegetation and climate change and the management implications. Cold Reg. Sci. Technol. 64, 46-56. doi: 10.1016/j.coldregions.2010.04.009

Kompas, T., and Kuk, R. (2008). Managing the Gulf of Papua prawn fishery: sustainability, maximum returns and cooperation between commercial fishing and indigenous fishing communities. Pac. Econ. Bull. 23, 29-38.

Koundouri, P., Karousakis, K., Assimacopoulos, D., Jeffrey, P., and Lange, M. A. (2006). Water Management in Arid and Semi-Arid Regions: Interdisciplinary Perspectives. Cheltenham: Edward Elgar Publishing.

Kuenzer, C., and Vo, Q. T. (2013). Assessing the ecosystem services value of Can Gio Mangrove Biosphere Reserve: combining earth-observation- and household-survey-based analyses. Appl. Geogr. 45:16.

Kuenzer, C., Campbell, I., Roch, M., Leinenkugel, L., Vo Quoc, T., and Dech, S. (2013). Understanding the impacts of hydropower developments in the context of upstream-downstream relations in the Mekong River Basin. Sustain. Sci. 8, 565-584. doi: 10.1007/s11625-012-0195-z

Kumar, K. K., and Rajan, P. D. (2012). Fish and Fisheries in Vembanad Lake. Consolidated report of Vembanad fish count 2008- 2011. New Delhi: CERC, 42.

Kumar, S. P. (2018). On the effect of hydrogen sulphide on primary productivity from retting area in Vembanad Lake, India. Indian J. Mar. Sci. 47, 378-380.

Lage, S., Costa, P. R., Moita, T., Eriksson, J., Rasmussen, U., and Rydberg, S. J. (2014). BMAA in shellfish from two Portuguese transitional water bodies suggests the marine dinoflagellate Gymnodinium catenatum as a potential BMAA source. Aquat. toxicol. 152, 131-138. doi: 10.1016/j.aquatox.2014.03.029

Lamoureux, S., Forbes, D. L., Bell, T., and Manson, G. K. (2015). “The impact of climate change on infrastructure in the western and central Canadian Arctic," in From Science to Policy in the Western and Central Canadian Arctic: an Integrated Regional Impact Study (IRIS) of Climate Change and Modernization, Chap. 7, eds G. A. Stern and A. Gaden (Québec: ArcticNet), 300-341.

Lanfredi, N. W., D’Onofrio, E. E., and Mazio, C. C. (1988). Variations of the mean sea level in the Southwest Atlantic Ocean. Cont Shelf Res 8, 1211-1220. doi: 10.1016/0278-4343(88)90002-7

Lang'at, J. K., and Kairo, J. G. (2008). Conservation and Management of Mangrove Forests in Kenya. Mombasa: Mangrove Reforestation Program, Kenya Marine and Fisheries Research Institute.

Lang'at, J., Kairo, J., Mencuccini, M., Bouillon, S., Skov, M., Waldron, S., et al. (2014). Rapid losses of surface elevation following tree girdling and cutting in tropical mangroves. PLoS One 10:e0118334. doi: 10.1371/journal.pone.0107868

Laxmilatha, P., and Appukuttan, K. K. (2002). A review of the black clam (Villorita cyprinoides) fishery of the Vembanad Lake. Indian J. Fish. 49, 85-91.

Lefcheck, J. S., David, J. W., Rebecca, R. M., Scott, R. M., and Robert, J. O. (2017). Multiple stressors threaten the imperiled coastal foundation species eelgrass
(Zostera marina) in Chesapeake Bay. USA. Glob. Change Biol. 23, 3474-3483. doi: $10.1111 /$ gcb. 13623

Lefcheck, J. S., Orth, R. J., Dennison, W. C., Wilcox, D. J., Murphy, R. R., Keisman, J., et al. (2018). Long-term nutrient reductions lead to the unprecedented recovery of a temperate coastal region. Proc. Natl. Acad. Sci. U.S.A. 115, 3658-3662. doi: 10.1073/pnas.1715798115

Lesack, L. F. W., Marsh, P., Hicks, F. E., and Forbes, D. L. (2013). Timing, duration, and magnitude of peak annual water levels during ice breakup in the Mackenzie Delta and the role of river discharge. Water Resour. Res. 39, 8234-8249. doi: 10.1002/2012WR013198

Lesack, L. F. W., Marsh, P., Hicks, F. E., and Forbes, D. L. (2014). Local spring warming drives earlier river-ice breakup in a large Arctic delta. Geophys. Res. Lett. 41, 1560-1566. doi: 10.1002/2013GL058761

Li, B., Liao, C. H., Zhang, X. D., Chen, H. L., Wang, Q., Chen, Z. Y., et al. (2009). Spartina alterniflora invasions in the Yangtze River estuary. China: an overview of current status and ecosystem effects. Ecol. Eng. 35, 511-520. doi: 10.1016/j.ecoleng.2008.05.013

Li, Y., Zhang, H. B., Chen, X. B., Tu, C., Luo, Y. M., and Christie, P. (2014). Distribution of heavy metals in soils of the Yellow River Delta: concentrations in different soil horizons and source identification. J. Soils Sediments 14, 1158-1168. doi: 10.1007/s11368-014-0861-0

Li, Y., Zhang, H. B., Fu, C. C., Tu, C., Luo, Y. M., and Christie, P. (2019). A red clay layer in soils of the Yellow River Delta: occurrence, properties and implications for elemental budgets and biogeochemical cycles. Catena 172, 469-479. doi: 10.1016/j.catena.2018.09.015

Li, Y., Zhang, H. B., Li, Q. B., Zhou, Q., Chen, X. B., Tu, C., et al. (2016). Characteristics of residual organochlorine pesticides in soils undue different land-use types on a coastal plain of the Yellow River Delta: concentrations in different soil horizons and source identification. Environ. Geochem. Health 38, 535-547. doi: 10.1007/s10653-015-9738-4

Liebezeit, G., and Rau, M. T. (2006). New Guinea mangroves - traditional usage and chemistry of natural products. Senck. Marit. 36, 1-10. doi: 10.1007/bf03043698

Liu, Y., and Huang, H. J. (2013). Characterization and mechanism of regional land subsidence in the Yellow River Delta. China. Nat. Hazards 68, 687-709. doi: 10.1007/s11069-013-0648-4

Loucks, C., Barber-Meyer, S., Hossain, M. A. A., Barlow, A., and Chowdhury, R. M. (2010). Sea level rise and tigers: predicted impacts to Bangladesh's Sundarbans mangroves. Clim. Change 98:291. doi: 10.1007/s10584-009-9761-5

Lovelock, C. E., and Duarte, C. M. (2019). Dimensions of Blue Carbon and emerging perspectives. Biol. Lett. 15:20180781. doi: 10.1098/rsbl.2018.0781

Luo, Y. M., Li, Y., Zhang, H. B., and Tu, C. (eds) (2017). Soil and environment of the Yellow River delta. Beijing: China Science Press, 002-038.

Ma, T., Li, X., Bai, J., Ding, S., Zhou, F., and Cui, B. (2019). Four decades' dynamics of coastal blue carbon storage driven by land use/land cover transformation under natural and anthropogenic processes in the Yellow River Delta, China. Sci. Total Environ. 655, 741-750. doi: 10.1016/j.scitotenv.2018.11.287

Ma, Z., Gan, X., Choi, C., Jing, K., Tang, S., Li, B., et al. (2007). Wintering bird communities in newly- formed wetland in the Yangtze River estuary. Ecol. Res. 22, 115-124. doi: 10.1007/s11284-006-0193-7

Ma, Z., Wang, Y., Gan, X., Li, B., Cai, Y., and Chen, J. (2009). Waterbird population changes in the wetlands at Chongming Dongtan in the Yangtze River estuary. China. Environ. Manag. 43, 1187-1200. doi: 10.1007/s00267-008-9247-7

MAERH (2003). Etude sur la dépollution industrielle dans le bassin versant du lac de Bizerte. Rapport. Tunis: Ministère de l'Agriculture, de l'Environnement et des Ressources Hydrauliques, 182.

Manson, G. K., and Solomon, S. M. (2007). Past and future forcing of Beaufort Sea coastal change. Atmos. Ocean. 45, 107-122. doi: 10.3137/ao.450204

Martini, I. P., Morrison, R. I. G., Abraham, K. F., Sergienko, L. A., and Jefferies, R. L. (2019). "Northern polar coastal wetlands: development, structure, and land use," in Coastal Wetlands: An Integrated Ecosystem Approach 2nd Edn, eds G. M. E. Perillo, E. Wolanski, D. R. Cahoon, and C. S. Hopkinson (Amsterdam: Elsevier), 153-186. doi: 10.1016/B978-0-444-63893-9. 00004-6

Mateo, R., Green, A. J., Lefranc, H., Baos, R., and Figuerola, J. (2007). Lead poisoning in wild birds from southern Spain: a comparative study of wetland areas and species affected, and trends over time. Ecotox. Environ. Safe. 66, $119-126$. 
McClanahanan, T. R., Mwagunib, S., and Muthiga, N. A. (2005). Management of the Kenyan coast. Ocean Coast. Manag. 48, 901-931. doi: 10.1016/j.ocecoaman. 2005.03.005

McKendry, J. E. (2009). A Socioeconomic Atlas for the Chesapeake Bay Watershed and Its Region. Available online at: https://www.chesapeakebay.net/content/ publications/cbp_46698.pdf

Mei, X. F., Dai, Z. J., Stephen, D., Gao, S., Wang, J., and Jiang, W. G. (2018). Modulation of extreme flood levels by impoundment significantly offset by floodplain loss downstream of the Three Gorges Dam. Geophys. Res. Lett. 45, 3147-3155. doi: 10.1002/2017GL076935

Millennium Ecosystem Assessment [MEA] (2005). Ecosystems and Human WellBeing: Wetlands and Water Synthesis. Washington, DC: World Resources Institute, 80

Miralles, J., Radakovitch, O., Cochran, J. K., Veron, A., and Masque, P. (2004). Multitracer study of anthropogenic contamination records in the Camargue, Southern France. Sci. Total Environ. 320, 63-72.

Mohan, M., Shylesh Chandran, M. S., Jayasooryan, K. K., and Ramasamy, E. V. (2014). Mercury in the sediments of Vembanad Lake, western coast of India. Environ. Monit. Assess. 186, 3321-3336. doi: 10.1007/s10661-014-3620-1

Moreira da Silva, M., Duarte, D., and Luís, C. (2019). "Metal contamination in Ria Formosa saltmarsh, sediments and halophyte vegetation," in Ria Formosa: Challenges of a Coastal Lagoon in a Changing Environment, 1st Edn, eds J. Aníbal, A. Gomes, I. Mendes, and D. Moura (Faro: University of Algarve), 99-107.

Morris, J. T., Barber, D. C., Callaway, J. C., Chambers, R., Hagen, S. C., Hopkinson, C. S., et al. (2016). Contributions of organic and inorganic matter to sediment volume and accretion in tidal wetlands at steady state. Earth's Future 4, 110-121. doi: 10.1002/2015EF000334

Mudge, S. M., and Duce, C. E. (2005). Identifying the source, transport path and sinks of sewage derived organic matter. Environ. Pollut. 136, 209-220. doi: 10.1016/j.envpol.2005.01.015

Nagelkerken, I., Van der Velde, G., Gorissen, M. W., Meijer, G. J., Van't Hof, T., and Den Hartog, C. (2000). Importance of mangroves, seagrass beds and the shallow coral reef as a nursery for important coral reef fishes, using a visual census technique. Estuar. Coast. Shelf Sci. 51, 31-44. doi: 10.1006/ecss.2000.0617

Najjar, R. G., Christopher, R. P., Mary, B. A., Denise, B., Carl, H., Michael, K., et al. (2010). Potential climate-change impacts on Chesapeake Bay. Estuar. Coast. Shelf S. 86, 1-20.

Narayanan, S. P., Thomas, A. P., and Sreekumar, B. (2011). Ornithofauna and its conservation in the Kuttanad wetlands, southern portion of Vembanad-Kole Ramsar site, India. J. Threat. Taxa 3, 1663-1676. doi: 10.11609/JoTT.o1870. 1663-76

National Fish and Wildlife Service (2016). Nutria Eradication Project. Nutria Biology and Identification. Available online at: https://www.fws.gov/ chesapeakenutriaproject/index.html (accessed August 28, 2016).

National Research Council [NRC]. (2010). Sea Level Rise and the Coastal Environment. Advancing the science of climate change. Washington, DC: NRC Press. 243-247.

Negandhi, K., Edwards, G., Kelleway, J. J., Howard, D., Safari, D., Saintilan, N., et al. (2019). Blue carbon potential of coastal wetland restoration varies with inundation, and rainfall. Sci. Rep. 9:4368. doi: 10.1038/s41598-019-40763-8

Neubauer, S. C., and Verhoeven, J. T. A. (2019). "Wetland effects on global climate: mechanisms, impacts, and management recommendations," in Wetlands: Ecosystem Services, Restoration and Wise Use, eds S. An, and J. T. A. Verhoeven (Cham: Springer), 39-62. doi: 10.1007/978-3-030-14861-4_3

Newton, A., Brito, A. C., Icely, J. D., Derolez, V., Clara, I., Angus, S., et al. (2018). Assessing, quantifying and valuing the ecosystem services of coastal lagoons. J. Nat. Conserv. 44, 50-65. doi: 10.1016/j.jnc.2018.02.009

Newton, A., Icely, J. D., Falcão, M., Nobre, A., Nunes, J. P., Ferreira, J. G., et al. (2003). Evaluation of eutrophication in the Ria Formosa coastal lagoon. Portugal. Cont. Shelf Res. 23, 1945-1961. doi: 10.1016/j.csr.2003.06.008

Newton, A., Icely, J., Cristina, S., Brito, A., Cardoso, A. C., Colijn, F., et al. (2013). An overview of ecological status, vulnerability and future perspectives of European large shallow, semi-enclosed coastal systems, lagoons and transitional waters. Estuar. Coast. Shelf Sci. 140, 95-122. doi: 10.1016/j.ecss.2013.05.023

O'Connor, J. J., Fest, B. J., Sievers, M., and Swearer, S. E. (2020). Impacts of land management practices on blue carbon stocks, and greenhouse gas fluxes in coastal ecosystems-A meta-analysis. Glob. Change Biol. 26, 1354-1366. doi: $10.1111 /$ gcb. 14946

Obu, J., Lantuit, H., Fritz, M., Pollard, W. H., Sachs, T., and Gunther, F. (2016). Relation between planimetric and volumetric measurements of permafrost coast erosion: a case study from Herschel Island, western Canadian Arctic. Polar Res. 35:303013. doi: 10.3402/polar.v35.303013

OECD (2015). OECD Urban Policy Reviews: China 2015. Paris: OECD Publishing, doi: 10.1787/9789264230040-en

O’Higgins, T., Cooper, P., Roth, E., Newton, A., Farmer, A., Goulding, I., et al. (2014). Temporal constraints on ecosystem management: definitions and examples from Europe's regional seas. Ecol. Soc. 19:46.

Oppenheimer, M., Glavovic, B. C., Hinkel, J., van de Wal, R., Magnan, A. K., AbdElgawad, A., et al. (2019). "Sea level rise and implications for low-lying islands, coasts and communities," in IPCC Special Report on the Ocean and Cryosphere in a Changing Climate, eds H.-O. Pörtner, et al. (Geneva: IPCC).

Ottinger, M., Clauss, K., and Kuenzer, C. (2016). Aquaculture: relevance, distribution, impacts and spatial assessments. Ocean Coast. Manag. 119, 244266. doi: 10.1016/j.ocecoaman.2015.10.015

Ottinger, M., Kuenzer, C., Liu, G. H., Wang, S. Q., and Dech, S. (2013). Monitoring land cover dynamics in the Yellow River Delta from 1995 to 2010 based on Landsat 5 TM. Appl. Geogr. 44, 53-68. doi: 10.1016/j.apgeog.2013.07.003

Owuor, M. A., Icely, J., and Newton, A. (2019a). Community perceptions of the status and threats facing mangroves of Mida Creek, Kenya: implications for community based management. Ocean Coast. Manag. 175, 172-179. doi: 10. 1016/j.ocecoaman.2019.03.027

Owuor, M. A., Icely, J., Newton, A., Nyunja, J., Otieno, P., Tuda, A. O., et al. (2017). Assessment of the flow of ecosystem service in an East African marine reserve. Ocean Coast. Manag. 140, 11-12.

Owuor, M. A., Mulwa, R., Otieno, P., Icely, J., and Newton, A. (2019b). Valuing mangrove biodiversity and ecosystem services: a deliberative choice experiment in Mida Creek. Kenya. Ecosyst. Serv. 40:101040. doi: 10.1016/j.ecoser.2019. 101040

Page, T., Murphy, M. E., Mizrahi, M., Cornelius, J. P., and Venter, M. (2016). Sustainability of wood-use in remote forest-dependent communities of Papua New Guinea. Forest Ecol. Manag. 382, 88-99. doi: 10.1016/j.foreco.2016. 09.043

Paolisso, M. (2008). Cultural models and cultural consensus of Chesapeake Bay blue crab and oyster fisheries. NAPA Bull. 28, 123-135. doi: 10.1525/napa.2007. 28.1.123

Parris, A., Bromirski, P., Burkett, V., Cayan, D., Culver, M., Hall, J., et al. (2012). Global Sea Level Rise Scenarios for the US National Climate Assessment. NOAA Tech Memo OAR CPO-1. Silver Spring, MA: NOAA.

Patrício, J., Elliott, M., Mazik, K., Papadopoulou, K. N., and Smith, C. J. (2016). DPSIR - two decades of trying to develop a unifying framework for marine environmental management? Front. Mar. Sci. 3:177. doi: 10.3389/fmars.2016. 00177

Percival, M., and Womersley, J. S. (1975). Floristics and ecology of the mangrove vegetation of Papua New Guinea, in: Botany Bulletin Lae. Papua New Guinea: Department of Forests, Division of Botany, 1-96.

Perillo, G. M. E. (1995). "Definition and geomorphologic classifications of estuaries," in Geomorphology and Sedimentology of Estuaries, Development in Sedimentology, Vol. 53, ed. G. M. E. Perillo (Amsterdam: Elsevier Science BV), 17-47. doi: 10.1016/s0070-4571(05)80022-6

Perillo, G. M. E., and Iribarne, O. O. (2003a). New mechanisms studied for creek formation in tidal flats: from crabs to tidal channels. EOS Am. Geophys. Union Trans. 84, 1-5.

Perillo, G. M. E., and Iribarne, O. O. (2003b). Processes of tidal channels develop in salt and freshwater marshes. Earth Surf. Proc. Land. 28, 1473-1482. doi: 10.1002/esp. 1018

Perillo, G. M. E., and Piccolo, M. C. (1991). Tidal response in the Bahía Blanca Estuary. J. Coast. Res. 7, 437-449.

Perillo, G. M. E., and Piccolo, M. C. (1999). Geomorphological and physical Characteristics of the Bahia Blanca Estuary, Argentina, eds G. M. E. Perillo, M. C. Piccolo, and M. Pino Quivira (Berlin: Springer Verlag), 195-216.

Perillo, G. M. E., and Piccolo, M. C., (2020). Physical oceanography of the Bahía Blanca Estuary. Estuar. Coast. Shelf Sci. 31, 303-317. 
Perillo, G. M. E., and Sequeira, M. E. (1989). Geomorphologic and sediment transport characteristics of the middle reach of the Bahía Blanca Estuary. Argentina. J. Geophys. Res. Oceans 94, 14351-14362.

Perillo, G., Wolanski, E., Cahoon, D., and Hopkinson, C. (eds) (2019). Coastal Wetlands: An Integrated Ecosystem Approach, 2nd Edn. Amsterdam: Elsevier, 1105.

Piccolo, M. C., and Perillo, G. M. E. (1990). Physical characteristics of the Bahía Blanca Estuary (Argentina). Estuar. Coast. Shelf S. 31, 303-317. doi: 10.1016/ 0272-7714(90)90106-2

Planning Commission Government of India (2008). Report on Visit to Vembanad Kol, Kerala, a Wetland Included Under the National Wetland Conservation and Management Programme of the Ministry of Environment and Forests, 29 June-1 July, 2008. New Delhi: Planning Commission, 22.

Pranovi, F., Franceschini, G., Casale, M., Zucchetta, M., Torricelli, P., and Giovanardi, O. (2006). An ecological imbalance induced by a non-native species: the Manila clam in the Venice Lagoon. Biol. Invasions 8, 595-609. doi: 10.1007/s10530-005-1602-5

Primavera, J. H. (2006). Overcoming the impacts of aquaculture on the coastal zone. Ocean Coast. Manag. 49, 531-545. doi: 10.1016/j.ocecoaman.2006.06.018

Rabalais, N. N., and Turner, R. E. (2016). Effects of the Deepwater Horizon oil spill on coastal habitats and fauna. Oceanography 29, 150-159. doi: 10.5670/ oceanog.2016.79

Rahman, M. M., Chongling, Y., Islam, K. S., and Haoliang, L. (2009). A brief review on pollution and ecotoxicologic effect on Sundarbans mangrove ecosystem in Bangladesh. Int. J. Environ. Eng. 1, 369-382.

Rahman, M. M., Jiang, Y., and Irvine, K. (2018). Assessing wetland services for improved development decision- making: a case study of mangroves in coastal Bangladesh. Wetlands Ecol. Manag. 26, 563-580. doi: 10.1007/s11273-0189592-0

Rahman, M. M., Rahman, M. M., and Islam, K. S. (2010). The causes of deterioration of Sundarban mangrove forest ecosystem of Bangladesh: conservation and sustainable management issues. AACL Bioflux 3, 77-90.

Ranjan, P., Ramanathan, A. L., Kumar, A., Singhal, R. K., Datta, D., and Venkatesh, M. (2018). Trace metal distribution, assessment and enrichment in the surface sediments of Sundarban mangrove ecosystem in India and Bangladesh. Mar. Pollut. Bull. 127, 541-547. doi: 10.1016/j.marpolbul.2017.11.047

Raposa, K. B., Wasson, K., Smith, E., Crooks, J. A., Delgado, P., Fernald, S. H., et al. (2016). Assessing tidal marsh resilience to sea-level rise at broad geographic scales with multi-metric indices. Biol. Conserv. 204, 263-275. doi: 10.1016/j. biocon.2016.10.015

Rashid, S. M. A., Khan, A., and Akonda, A. W. (1994). "Fauna," in Mangrove of the Sundarbans, eds Z. Hussain, and G. Acharya (Bangkok: IUCN), 125-132.

Riba, I., Garcia-Luque, E., Blasco, J., and DelValls, T. A. (2003). Bioavailability of heavy metals bound to estuarine sediments as a function of $\mathrm{pH}$ and salinity values. Chem. Speciation Bioavailability 15, 101-114.

Robertson, A. I, and Alongi, D. M. (1995). Role of riverine mangrove forests in organic carbon export to the tropical coastal ocean: a preliminary mass balance for the Fly Delta (Papua New Guinea). Geo-Mar. Lett. 15, 134-139. doi: $10.1007 /$ bf01204454

Rova, S., Pranovi, F., and Muller, F. (2015). Provision of ecosystem services in the lagoon of Venice (Italy): an initial spatial assessment. Ecohydrol. Hydrobiol. 15, 13-25. doi: 10.1016/j.ecohyd.2014.12.001

Ruz, M. -H., Héquette, A., and Hill, P. R. (1992). A model of coastal evolution in a transgressed thermokarst topography, Canadian Beaufort Sea. Mar. Geol. 106, 25-278.

Rybicki, N. B., and Landwehr, J. M. (2007). “Submerged aquatic vegetation," in Synthesis of U.S. Geological Survey Science for the Chesapeake Bay Ecosystem and Implications for Environmental Management: U.S. Geological Survey Circular 1316, Ed. S.W. Phillips (Reston, VA: U.S. Geological Survey), 46-49.

Sahraoui, I., Sakka, H. A., Hadj, M. H., Leger, C., and Bates, S. S. (2009). Blooms of the diatoms genus Pseudo-nitzschia H. Peragallo in Bizerte Lagoon (Tunisia, SW Mediterranean). Diatom Res. 24, 175-190. doi: 10.1080/0269249x.2009.9705789

Saied, M., and Elloumi, M. J. (2007). Prise en Compte des Besoins Écologiques de l'Ichkeul dans la gestion de l'eau en Tunisie. Gestion de la demande en eau en Méditerranée. Available online at: http://planbleu.org/sites/default/files/upload/ files/Eco_5_TN_47_Saied_final_FR.pdf

Sakka Hlaili, A., Chikhaoui, M. A., El Grami, B., and Hadj Mabrouk, H. (2006). Effect of $\mathrm{N}$ and $\mathrm{P}$ supply on phytoplankton in Bizerte lagoon (Western
Mediterranean). J. Exp. Mar. Biol. 333, 79-96. doi: 10.1016/j.jembe.2005 12.049

Sakka Hlaili, A., El Grami, B., Hadj Mabrouk, H., Gosselin, M., and Hamel, D. (2007). Phytoplankton growth and microzooplanton grazing rates in a restricted Mediterranean lagoon (Bizerte lagoon, Tunisia). Mar. Biol. 151, 767-783. doi: 10.1007/s00227-006-0522-y

Sarretta, A., Pillon, S., Molinaroli, E., Guerzoni, S., and Fontolan, G. (2009). Sediment budget in the Lagoon of Venice, Italy. Cont. Shelf Res. 30, 934-949. doi: 10.1016/j.csr.2009.07.002

Sasmito, S. D., Sillanpää, M., Hayes, M. A., Bachri, S., Saragi-Sasmito, M. F., Sidik, F., et al. (2020). Mangrove blue carbon stocks and dynamics are controlled by hydrogeomorphic settings and land-use change. Glob. Change Biol. 2020, 1-12. doi: $10.1111 /$ gcb.15056

Savoure, B. (1977). Etude hydrobiologique des lagunes du Nord de la Tunisie. Hydrobiologia 56, 209-224. doi: 10.1007/bf00017507

Scott, D. A. (1980). A Preliminary Inventory of Wetlands of International Importance for Waterfowl in Western Europe and North-West Africa. Slimbridge: IWRB.

Selvam, A. P., Priya, S. L., Banerjee, K., Hariharan, G., Purvaja, R., and Ramesh, R. (2012). Heavy metal assessment using geochemical and statistical tools in the surface sediments of Vembanad Lake, Southwest Coast of India. Environ. Monit. Assess. 184, 5899-5915. doi: 10.1007/s10661-011-2389-2388

Semeoshenkova, V., and Newton, A. (2015). Overview of erosion and beach quality issues in three Southern European countries: Portugal. Spain and Italy. Ocean Coast. Manag. 118, 12-21. doi: 10.1016/j.ocecoaman.2015. 08.013

Serrano, O., Kelleway, J. J., Lovelock, C., and Lavery, P. S. (2019). “Conservation of blue carbon ecosystems for climate change mitigation and adaptation," in Coastal Wetlands, eds G. Perillo, D. R. Cahoon, G. M. E. Perillo, and E. Wolanski (Amsterdam: Elsevier), 965-996. doi: 10.1016/b978-0-444-63893-9. 00028-9

Severini, M. D. F., Carbone, M. E., Villagran, D. M., and Marcovecchio, J. E. (2018). Toxic metals in a highly urbanized industry-impacted estuary (Bahia Blanca Estuary, Argentina): spatio-temporal analysis based on GIS. Environ. Earth Sci. 77, 393

Shearman, P. L. (2010). Recent change in the extent of mangroves in the northern Gulf of Papua, Papua New Guinea. Ambio 39, 181-189. doi: 10.1007/s13280010-0025-4

Shearman, P., Bryan, J., and Walsh, J. P. (2013). Trends in deltaic change over three decades in the Asia-Pacific region. J. Coastal Res. 29, 1169-1183.

Shepard, C. C., Crain, C. M., and Beck, M. W. (2011). The protective role of coastal marshes: a systematic review and meta-analysis. PLoS One 6:e27374. doi: 10.1371/journal.pone.0027374

Simonetti, P., Botté, S. E., and Marcovecchio, J. E. (2017). Occurrence and spatial distribution of metals in intertidal sediments of a temperate estuarine system (Bahía Blanca, Argentina). Environ. Earth Sci. 76:636.

Smart, M. (2004). River Flow Regulation and Wetland Conservation in a Dry Country: Ichkeul, Tunisia. Assessment and Provision of Environmental flows in Mediterranean Watercourses. Mediterranean case study. IUCN Report document. Available online at: http://cmsdata.iucn.org/downloads/tunisia.pdf (accessed June 17, 2014).

Solidoro, C., Bandelj, V., Aubry Bernardi, F., Camatti, E., Ciavatta, S., Cossarini, G., et al. (2010). "Response of the Venice Lagoon ecosystem to natural and anthropogenic pressures over the Last 50 Years," in Coastal Lagoons: Critical Habitats of Environmental Change, eds M. J. Kennish and H. W. Paerl (Boca Raton, FL: CRC Press), 483-511. doi: 10.1201/ebk142008830 4-c19

Spalding, M., McIvor, A., Tonneijck, F. H., Tol, S., and van Eijk, P. (2014). Mangroves for Coastal Defence. Guidelines for Coastal Managers \& Policy Makers. Wageningen: Wetlands International, 42.

Speake, M. A., Carbone, M. E., and Spetter, C. V. (2020). Análisis del sistema socio-ecológico del estuario Bahía Blanca (Argentina) y su impacto en los servicios ecosistémicos y el Bienestar Humano. Buenos Aires: National Council for Scientific and Technical Research.

Stephenson, S. A. (2004). Harvest Studies in the Inuvialuit Settlement Region, Northwest Territories, Canada, 1999 and 2001-2003. Winnipeg, MB: Resource Management and Aboriginal Affairs, Central and Arctic Region, Fisheries and Oceans Canada 
Strauss, B. H. (2013). Rapid accumulation of committed sea-level rise from global warming. Proc. Natl. Acad. Sci. U.S.A. 110, 13699-13700. doi: 10.1073/pnas. 1312464110

Steckler, M. S., Nooner, S. L., Akhter, S. H., Chowdhury, S. K., Bettadpur, S., Seeber, L. et al. (2010). Modeling Earth deformation from monsoonal flooding in Bangladesh using hydrographic, GPS, and Gravity Recovery and Climate Experiment (GRACE) data. J. Geophys. Res. Solid Earth 115:B08407. doi: 10. 1029/2009JB007018

Syvitski, J. P. M., and Saito, Y. (2007). Morphodynamics of deltas under the influence of humans. Glob. Planet. Change 57, 261-282. doi: 10.1016/j. gloplacha.2006.12.001

Syvitski, J. P., Kettner, A. J., Overeem, I., Hutton, E. W., Hannon, M. T., Brakenridge, G. R., et al. (2009). Sinking deltas due to human activities. Nat. Geosci. 2, 1-6.

Tamim, M. M., Dhar, A., and Hossain, M. S. (2013). Fly ash in Bangladesh- an overview. Int. J. Sci. Eng. Res. 4, 1-4.

Tamisier, A., and Boudouresque, C. F. (1994). "Aquatic bird populations as possible indicators of seasonal nutrient flow at Ichkeul lake, Tunisia," in Aquatic Birds in the Trophic Web of Lakes. Hydrobiologia, Vol. 279/280, ed. J. J. Kerekes (Dordrecht: Kluwer), 149-156. doi: 10.1007/978-94-011-1128-7_14

Tamisier, A., Dehorter, O., Defosse, A., Poydenot, F., Gravez, V., and Boudouresque, C. F. (2000). "Benefits, costs and risks for a field biologist. Ichkeul Lake Tunisia, a case atudy," in Limnology and Aquatic Birds Modelling Aquatic Ecosystem in Monitoring, Modelling and Management, eds F. A. Comin, J. A. Herrera, and J. Ramfrez (Mérida: Universidat Autonoma de Yucatan), 185-203.

Tanski, G., Wagner, D., Knoblauch, C., Fritz, M., Sachs, T., and Lantuit, H. (2019). Rapid CO2 release from eroding permafrost in seawater. Geophys. Res. Lett. 46, 11244-11252. doi: 10.1029/2019GL084303

Tavecchia, G., Pradel, R., Lebreton, J. D., Johnson, A. R., and Mondain-Monval, J. Y. (2001). The effect of lead exposure on survival of adult mallards in the Camargue, southern France. J. Appl. Ecol. 38, 1197-1207.

Tessler, Z. D., Vörösmarty, C. J., Grossberg, M., Gladkova, I., Aizenman, H., Syvitski, J. P. M., et al. (2015). Profiling risk and sustainability in coastal deltas of the world. Science 349, 638-639.

Thienpont, J. R., Kokelj, S. V., Korosi, J. B., Cheng, E. S., Desjardins, C., Kimpe, L. E., et al. (2013). Exploratory hydrocarbon drilling impacts to Arctic lake ecosystems. PLoS One 8:e78875. doi: 10.1371/journal.pone.0078875

Toan, P. V., Sebesvari, S., Bläsing, M., and Renaud, F. (2013). Pesticide management and their residues in sediments and surface and drinking water in the Mekong Delta, Vietnam. Sci. Total Environ. 45, 28-39. doi: 10.1016/j. scitotenv.2013.02.026

Todd, B. J., and Dallimore, S. R. (1998). Electromagnetic and geological transect across permafrost terrain, Mackenzie River delta, Canada. Geophysics 63, 19141924. doi: $10.1190 / 1.1444484$

Torio, D. D., and Chmura, G. L. (2013). Assessing coastal squeeze of tidal wetlands. J. Coastal Res. 29, 1049-1061. doi: 10.2112/jcoastres-d-12-00162.1

Trabelsi, Y., Gharbi, F., El Ghali, A., Oueslati, M., Samaali, M., Abdelli, W., et al. (2012). Recent sedimentation rates in Garaet El Ichkeul Lake, NW Tunisia, as affected by the construction of dams and a regulatory sluice. J. Soils Sediment 12, 784-796. doi: 10.1007/s11368-012-0496-y

Turki, S., Balti, N., and Ben Janet, H. (2007). First bloom of dinoflagellate Alexandrium catenella in Bizerte Lagoon (northern Tunisia). Harmful Algae News 35, 7-9.

Turki, S., Dhib, A., Belakhal, M. F., Frossard, V., Balti, N., Kharrat, R., et al. (2014). Harmful algal blooms (HABs) associated with phycotoxins in shellish: what can be learned from five years of monitoring in Bizerte Lagoon (Southern Mediterranean Sea)? Ecol. Eng. 67, 39-47. doi: 10.1016/j.ecoleng.2014.03.028

Turner, R. E. (1977). Intertidal vegetation and commercial yields of penaeid shrimp. Trans. Am. Fish. Soc. 106, 411-416. doi: 10.1577/1548-8659(1977) 106<411:ivacyo $>2.0 . \operatorname{co} ; 2$

Turner, R. E. (2007). Geomorphology and perception in New Orleans after Iberville and Bienville. Technol. Soc. 29, 227-238. doi: 10.1016/j.techsoc.2007. 01.013

Turner, R. E. (2017). The mineral sediment loading of the modern Mississippi River Delta: What is the restoration baseline? J. Coast. Conserv. 21, 867-872. doi: $10.1007 / \mathrm{s} 11852-017-0547-\mathrm{z}$
Turner, R. E., and McClenachan, G. (2018). Reversing wetland death from 35,000 cuts: opportunities to restore Louisiana's dredged canals. PLoS One 13:e0207717. doi: 10.1371/journal.pone.0207717

Turner, R. E., and Rabalais, N. N. (2003). Linking landscape and water quality in the Mississippi River basin for 200 years. Bioscience 53, 563-572.

Turner, R. E., and Rabalais, N. N. (2018). World Seas: An Environmental Evaluation, Volume I: Europe, The Americas and West Africa, Vol. The Gulf of Mexico, Chap. 18, ed. C. Shepard (Cambridge: Academic Press), 445-464.

Turner, R. E., Kearney, M. S., and Parkinson, R. W. (2018). Sea level rise tipping point of delta survival. J. Coast. Res. 34, 470-474. doi: 10.2112/JCOASTRES-D17-00068.1

Turner, R. E., McClenachan, G., and Tweel, A. W. (2016). Islands in the oil: quantifying salt marsh shoreline erosion after the Deepwater Horizon oiling. Mar. Pollut. Bull. 110, 316-323. doi: 10.1016/j.marpolbul.2016.06.046

Turner, R. E., Rabalais, N. N., Overton, E. B., Meyer, B. M., McClenachan, G., Swenson, E. M., et al. (2019). Oiling the continental shelf and coastal wetlands over eight years after the 2010 Deepwater Horizon oil spill. Environ. Pollut. 252, 1367-1376. doi: 10.1016/j.envpol.2019.05.134

Tweel, A. W., and Turner, R. E. (2012). Watershed land use and river engineering drive wetland formation and loss in the Mississippi River birdfoot delta. Limnol. Oceanogr. 57, 18-28. doi: 10.4319/lo.2012.57.1.0018

Tweel, A. W., and Turner, R. E. (2014). Contribution of tropical cyclones to the sediment budget for coastal wetlands in Louisiana, USA. Landscape Ecol. 29, 1083-1094. doi: 10.1007/s10980-014-0047-6

Ubertini, M., Lagarde, F., Mortreux, S., Le Gall, P., Chiantella, C., Fiandrino, A., et al. (2017). Gametogenesis, spawning behavior and larval abundance of the Pacific oyster Crassostrea gigas in the Thau lagoon: \#vidence of an environmentdependent strategy. Aquaculture 473, 51-61. doi: 10.1016/j.aquaculture.2017. 01.025

Varkey, L. M., Kumar, P., Mridha, N., Sekhar, I., and Sahoo, R. N. (2016). Ecosystem services and fishery production dynamics of wetland ecosystem: an appraisal of Alappuzha District of Kerala. India. Fish. Technol. 53:2.

Veríssimo, F., Flávio, M., and João, J. (2019). "The Role of Ria Formosa as a Waste Water Receiver," in Ria Formosa: Challenges of a Coastal Lagoon in a Changing Environment, 1st Edn, eds J. Aníbal, A. Gomes, I. Mendes, and D. Moura (Faro: University of Algarve), 47-65.

Vermaire, J. C., Pisaric, M. F. J., Thienpont, J. R., Courtney Mustaphi, C. J., Kokelj, S. V., and Smol, J. P. (2013). Arctic climate warming and sea ice declines lead to increased storm surge activity. Geophy. Res. Lett. 40, 1386-1390. doi: $10.1002 /$ grl50191

Vo, Q. T., Kuenzer, C., and Oppelt, N. (2015). How remote sensing supports mangrove ecosystem service valuation: a case study in Ca Mau Province, Vietnam. Ecosyst. Ser. 14, 67-75. doi: 10.1016/j.ecoser.2015.04.007

Vo, Q. T., Kuenzer, C., Quang, M., Moder, F., and Oppelt, N. (2012). Review of valuation methods for mangrove ecosystem services. J. Ecol. Indicat. 23, 431-446. doi: 10.1016/j.ecolind.2012.04.022

Wahid, S. M., Babel, M. S., and Bhuiyan, A. R. (2007). Hydrologic monitoring and analysis in the Sundarbans mangrove ecosystem, Bangladesh. J. Hydrol. 332, 381-395. doi: 10.1016/j.jhydrol.2006.07.016

Walker, D. A., and Peirce, J. L. (2015). Rapid Arctic Transitions due to Infrastructure and Climate (RATIC): A Contribution to ICARP III. Alaska Geobotany Center Publication AGC 15-02. Fairbanks: University of Alaska Fairbanks.

Wang, H. J., Wu, X., Bi, N. S., Li, S., Yuan, P., Wang, A. M., et al. (2017). Impacts of the dam-oriented water-sediment regulation system on the lower reaches of the Yellow River (Huanghe): a review. Glob. Planet Change 157, 93-113. doi: 10.1016/..gloplacha.2017.08.005

Wang, L. L., Yang, Z. F., Niu, J. F., and Wang, J. Y. (2009). Characterization, ecological risk assessment and source diagnostics of polycyclic aromatic hydrocarbons in water column of the Yellow River Delta, one of the most plenty biodiversity zones in the world. J. Hazard Mater. 169, 460-465. doi: 10.1016/j.jhazmat.2009.03.125

Ward, R. D., Friess, D. A., Day, R. H., and Mackenzie, R. A. (2016). Impacts of climate change on mangrove ecosystems: a region by region overview. Ecosyst. Health Sustain. 2:e01211. doi: 10.1002/ehs2.1211

Webber, M., Calumpong, H., Ferreira, F., Granek, E., Green, S., Ruwa, R., et al. (2016). Mangroves. Chapter 48, Section BII Marine Ecosystems and Habitats. United Nations World Ocean Assessment. Available online 
at: http://www.un.org/Depts/los/global_reporting/WOA_RPROC/Chapter_48. pdf (accessed August 13, 2016).

Wesche, S. D., and Chan, H. M. (2010). Adapting to the impacts of climate change on food security among Inuit in the Western Canadian Arctic. Ecohealth 7, 361-337.

White, W. T., Baje, L., Simpfendorfer, C. A., Appleyard, S. A., Chin, A., Sabub, B., et al. (2019). Elasmobranch bycatch in the demersal prawn trawl fishery in the Gulf of Papua, Papua New Guinea. Sci. Rep. 9:9254. doi: 10.1038/s41598-01945715-w

Witman, S. (2017). Coastal wetlands effectively sequester "blue carbon". Eos 98, doi: 10.1029/2017EO079397

Wohlfart, C., Kuenzer, C., Cui, C., and Liu, G. (2016). Socio-ecological challenges in the Yellow River basin (China): a review. Environ. Earth Sci. 75:1066.

Yang, H. F., Yang, S. L., Meng, Y., Xu, K. H., Luo, X. X., Wu, C. S., et al. (2018). Recent coarsening of sediments on the southern Yangtze subaqueous delta front: a response to river damming. Cont. Shelf Res. 155, 45-51. doi: 10.1016/ j.csr.2018.01.012

Yang, S. L., Zhang, J., Zhu, J., Smith, J. P., Dai, S. B., Gao, A., et al. (2005). Impact of dams on Yangtze River sediment supply to the sea and delta intertidal wetland response. J. Geophys. Res- Earth 110: F03006.

Zaaboub, N., Ounis, A., Helali, M. A., Béjaoui, B., Lillebø, A. I., Ferreira da Silva, E., et al. (2014). Phosphorus speciation in sediments and assessment of nutrient exchange at the water-sediment interface in a Mediterranean lagoon: implications for management and restoration. Ecol. Eng. 73, 115-125. doi: 10.1016/j.ecoleng.2014.09.017

Zacarias, D. A., Williams, A. T., and Newton, A. (2011). Recreation carrying capacity estimations to support beach management at Praia de Faro. Portugal. Appl. Geogr. 31, 1075-1081. doi: 10.1016/j.apgeog.2011.01.020

Zairi, M. (1997). Impact de la gestion des eaux du Nord et de l'activité industrielle correspondante sue le biotope du Lac Ichkeul. Paris: UNESCO.

Zhang, H., Chen, X. B., and Luo, Y. M. (2016). An overview of ecohydrology of the Yellow River delta wetland. Ecohydrol. Hydrobiol. 16, 39-44. doi: 10.1016/ j.ecohyd.2015.10.001

Zhang, Q., Damian, C., Brady, W. R., Boynton, A., and William, P. B. (2015). Long-term trends if nutrients and sediment from the non-tidal Chesapeake Bay watershed: an assessment of progress by river and season. J. Am. Water Res. Ass. 51, 1534-1555. doi: 10.1111/1752-1688.12327
Zhang, T. T., Zeng, S. L., Gao, Y., Ouyang, Z. T., Li, B., Fang, C. M., et al. (2011). Assessing impact of land uses on land salinization in the Yellow River Delta, China using an integrated and spatial statistical model. Land Use Policy 28, 857-866. doi: 10.1016/j.landusepol.2011. 03.002

Zhao, B., Kreuter, U., Li, B., Ma, Z., Chen, J., and Nakagoshi, N. (2004). An ecosystem service value assessment of land-use change on Chongming Island, China. Land Use Policy 21, 139-148. doi: 10.1016/j.landusepol.2003. 10.003

Zhao, B., Yan, Y., Guo, H., He, M., Gu, Y., and Li, B. (2009). Monitoring rapid vegetation succession in estuarine wetland using time series MODIS-based indicators: an application in the Yangtze River Delta area. Ecol Indic. 9, 346-356. doi: 10.1016/j.ecolind.2008.05.009

Zhao, S., Zhu, L., Wang, T., and Li, D. (2014). Suspended microplastics in the surface water of the Yangtze Estuary System, China: first observations on occurrence, distribution. Mar. Pollut. Bull. 86, 562-568. doi: 10.1016/j. marpolbul.2014.06.032

Zilio, M. I., London, S., Perillo, G. M. E., and Piccolo, M. C. (2013). The social cost of dredging: the Bahía Blanca Estuary case. Ocean Coast. Manag. 71, 195-120.

Conflict of Interest: JI is senior researcher with the research centre CIMA at the University of Algarve, Portugal and is also the co-owner of the Portuguese company Sagremarisco-Viveiros de Marisco Lda.

The authors declare that the research was conducted in the absence of any commercial or financial relationships that could be construed as a potential conflict of interest.

Copyright $\odot 2020$ Newton, Icely, Cristina, Perillo, Turner, Ashan, Cragg, Luo, Tu, Li, Zhang, Ramesh, Forbes, Solidoro, Béjaoui, Gao, Pastres, Kelsey, Taillie, Nhan, Brito, de Lima and Kuenzer. This is an open-access article distributed under the terms of the Creative Commons Attribution License (CC BY). The use, distribution or reproduction in other forums is permitted, provided the original author(s) and the copyright owner(s) are credited and that the original publication in this journal is cited, in accordance with accepted academic practice. No use, distribution or reproduction is permitted which does not comply with these terms. 